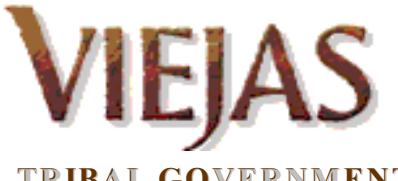

TRIBAL GOVERNMENT

\title{
Renewable Energy Development on Tribal Lands of Viejas
}

FINAL DRAFT REPORT

B\&V Project Number 135650

\section{September 2005}

Black \& Veatch Corporation

11401 Lamar

Overland Park, Kansas 66211

Tel: (913) 458-2000 www.bv.com

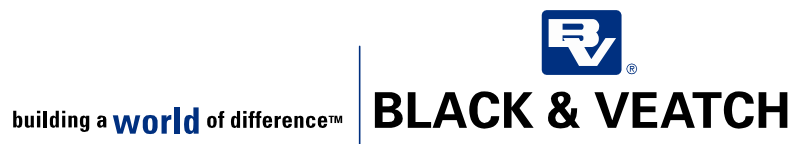




\section{Principal Investigators:}

Mike Elenbaas, Project Manager

Terrance Meyer, Project Engineer

Ryan Jacobson

Ryan Pletka

Gary Wilmes 


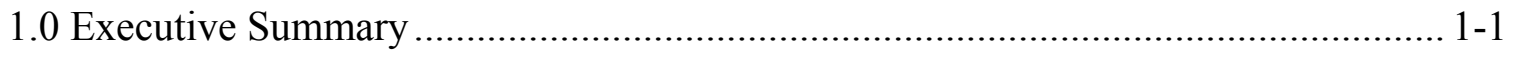

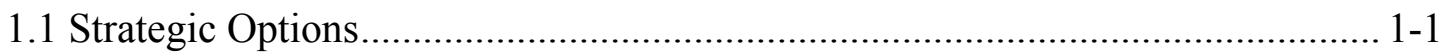

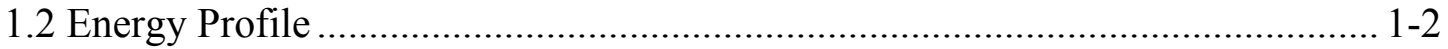

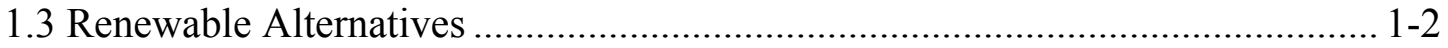

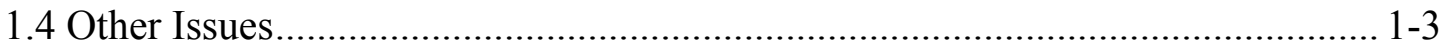

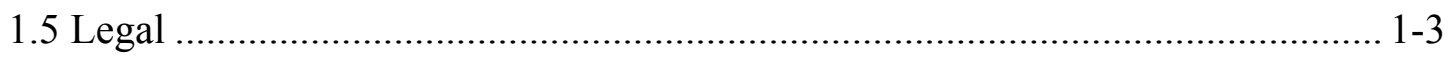

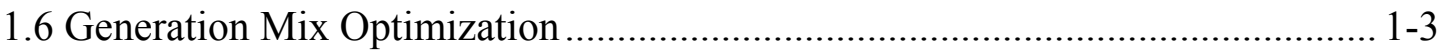

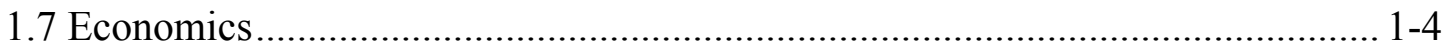

1.7.1 Net Metering Planning Scenario ............................................................ 1-4

1.7.2 Interconnected Utility Planning Scenario ................................................... 1-5

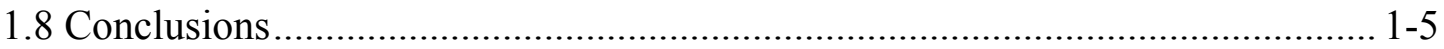

2.0 Introduction

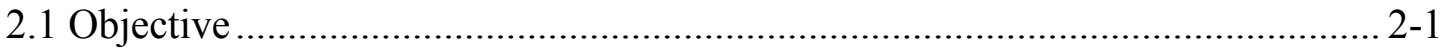

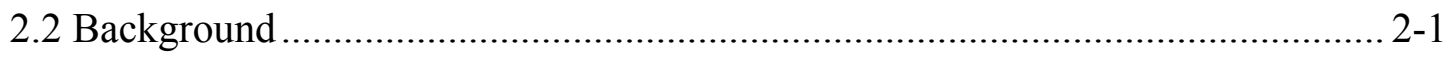

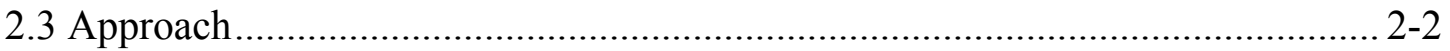

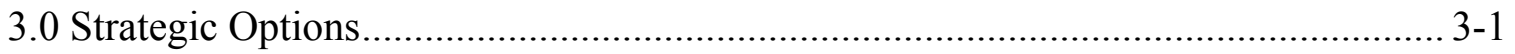

3.1 Net Metering on Individual Accounts.......................................................... 3-1

3.2 Tribal Utility Interactive with the Grid........................................................ 3-2

3.3 Tribal Utility Independent of the Grid ............................................................. 3-3

4.0 Detailed Viejas Energy Profile ………….......................................................... 4-1

4.1 Customer Load Profile.................................................................................. 4-1

4.2 Projected Peak Demand ............................................................................. 4-2

4.3 Hourly Load Profile ........................................................................................ 4-3

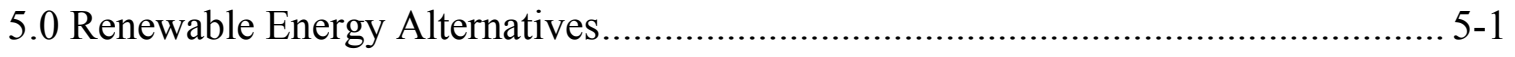

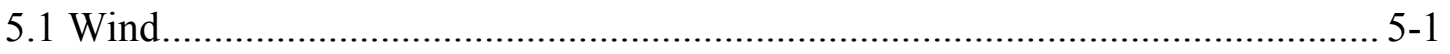

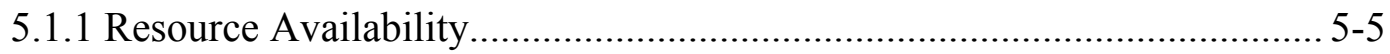

5.1.2 Site Assessment / Selection ………................................................... 5-7

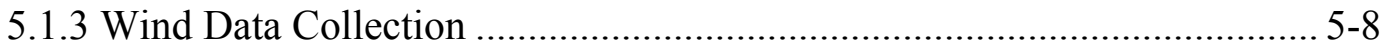

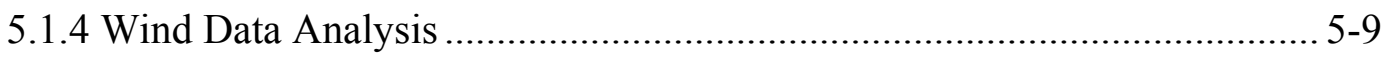

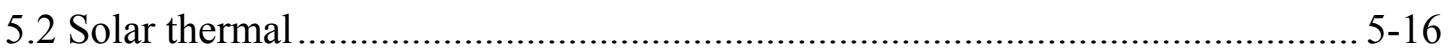

5.2.1 Technical Description ..................................................................... 5-16 


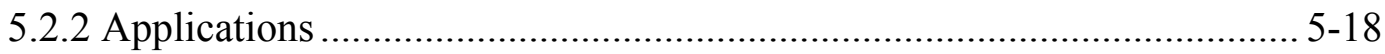

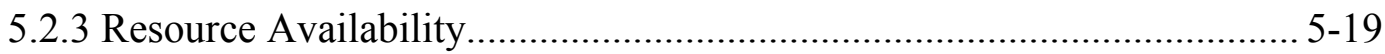

5.2.4 Cost and Performance Characteristics ……….................................. 5-20

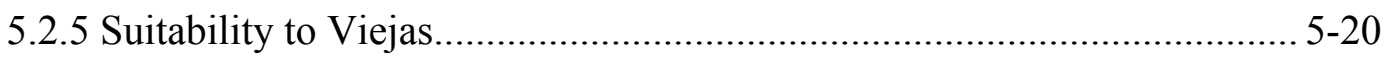

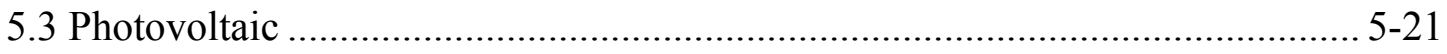

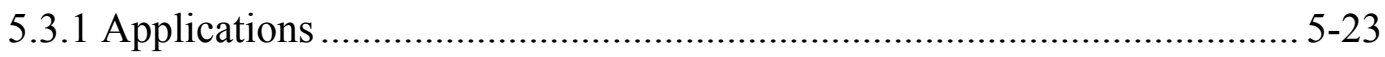

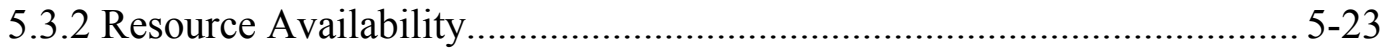

5.3.3 Cost and Performance Characteristics ………………………............. 5-24

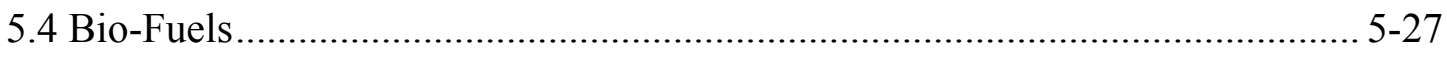

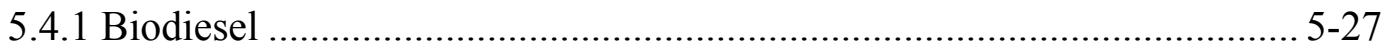

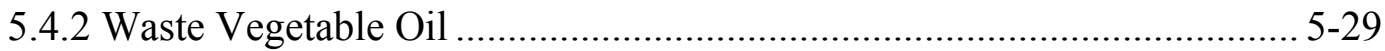

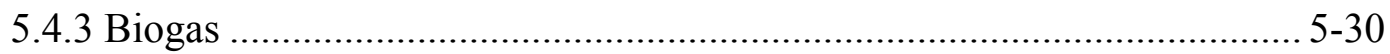

5.5 Cogeneration

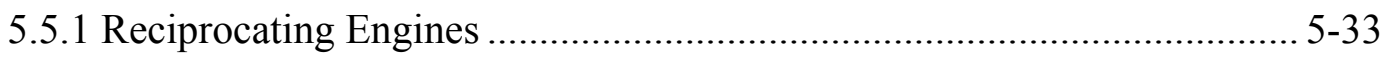

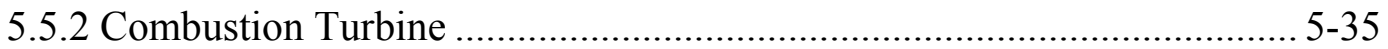

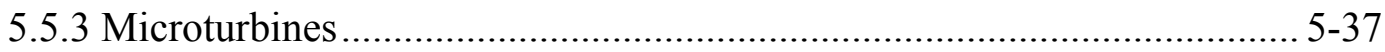

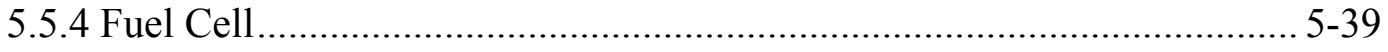

5.5.5 Commercial Hot water................................................................ 5-42

5.5.6 Commercial Absorption Cooling ………………................................ 5-42

5.5.7 Sludge Drying .................................................................................... 5-42

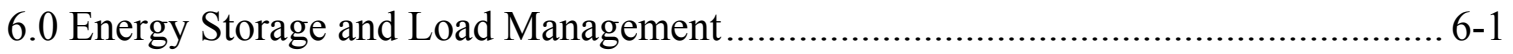

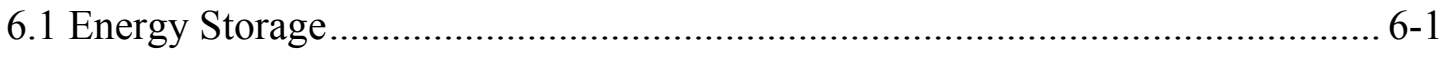

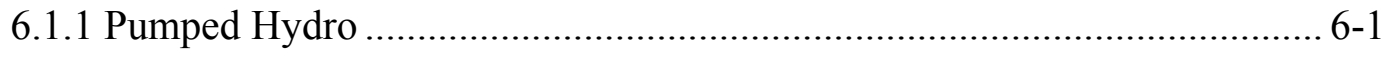

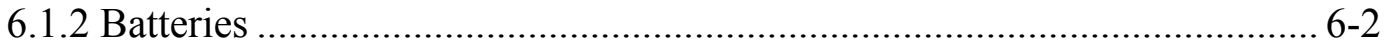

6.1.3 Compressed Air Energy Storage.......................................................... 6-3

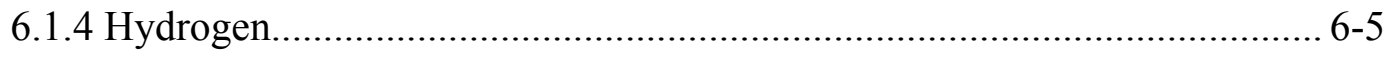

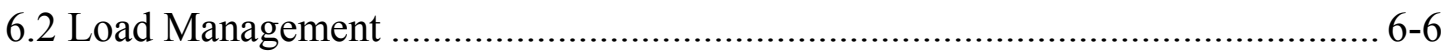

6.2.1 Dispatchable Loads ........................................................................ 6-6

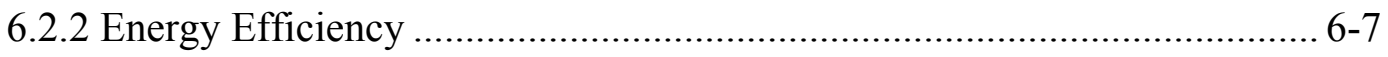

6.3 Energy Strategy

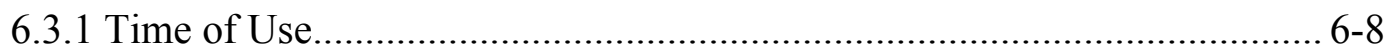

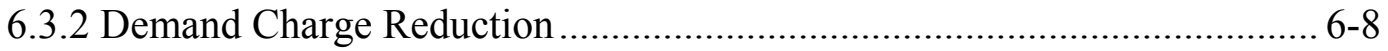

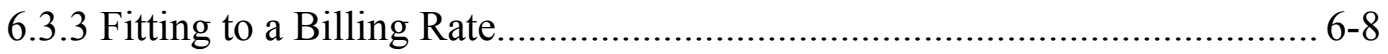

7.0 Electrical Interconnection .................................................................................. 7-1

7.1 Net Metering on Individual Accounts........................................................... 7-1 
7.1.1 Severance Scenario 1 (Net Metering) ...................................................... 7-1

7.2 Tribal Utility Interactive with the Grid .......................................................... 7-2

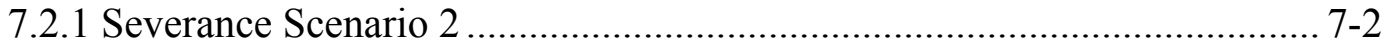

7.3 Tribal Utility Independent of the Grid ......................................................... 7-3

7.3.1 Severance Scenario 3 (Dedicated Distribution Line).................................. 7-3

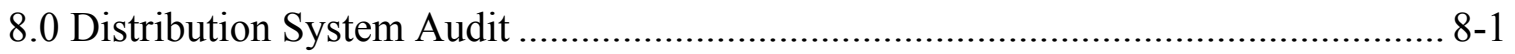

8.1 Distribution System Overview..................................................................... 8-1

8.2 Distribution System Condition and Information.............................................. 8-1

8.3 Distribution System Valuation...................................................................... 8-1

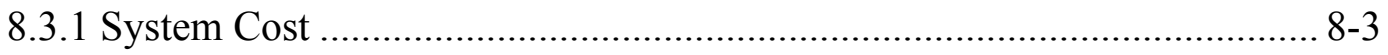

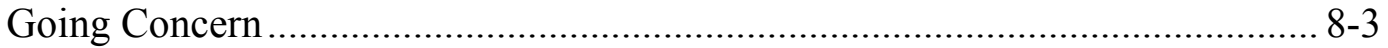

8.3.2 Reconfiguration Costs.......................................................................... 8-4

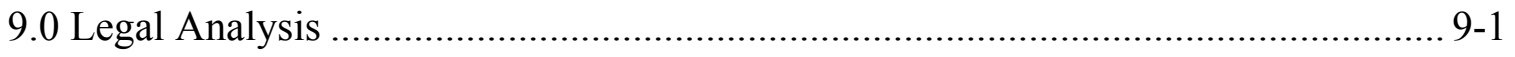

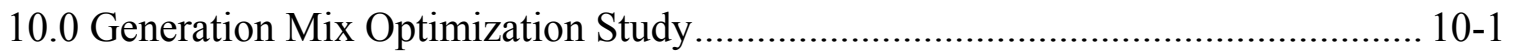

10.1 Optimization Process ........................................................................... 10-1

10.1.1 Levelized Cost Screening ……...................................................... 10-1

10.2 Planning and Production Costing Methodology …….................................... 10-2

10.3 Key Assumptions Overview ……………………............................... 10-3

10.4 Levelized Cost Screening Results............................................................... 10-3

10.5 Evaluation of Planning Scenarios ........................................................... 10-5

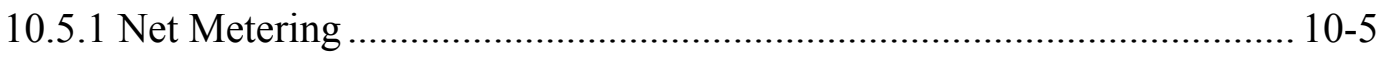

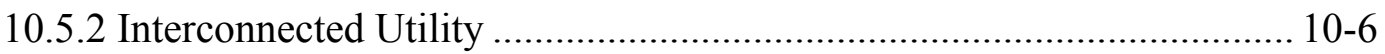

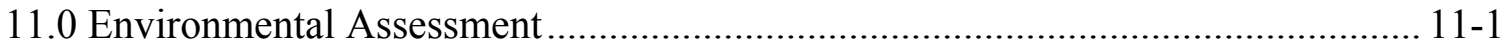

11.1 Wind

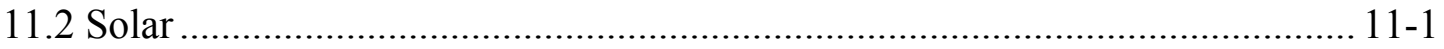

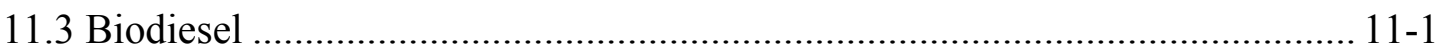

11.4 Pumped Hydro .................................................................................... 11-2

11.5 Cleveland National Forrest …………........................................................ 11-2

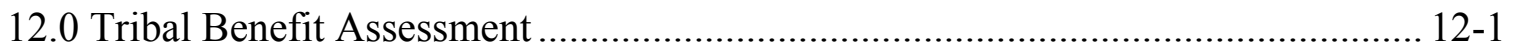

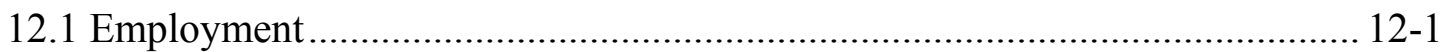

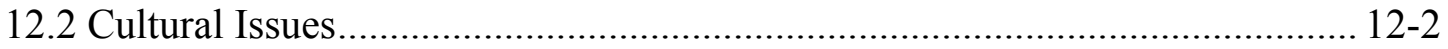

12.3 Social Issues.................................................................................... 12-2 
13.0 Economic Assessment ………….......................................................... 13-1

13.1 Economic Assessment of Planning Scenarios ................................................ 13-1

13.1.1 Net Metering Planning Scenario ..................................................... 13-1

13.1.2 Interconnected Utility Planning Scenario ………................................. 13-2

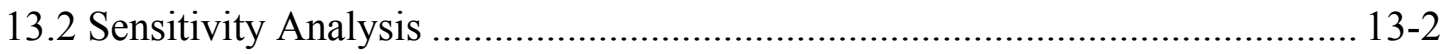

13.2.1 Net Metering Sensitivity Analysis ..................................................... 13-2

13.2.2 Interconnected Utility Sensitivity Analysis ........................................... 13-3

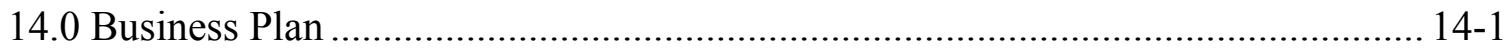

14.1 Self Generation/Net Metering Projects ..................................................... 14-1

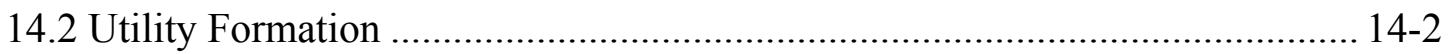

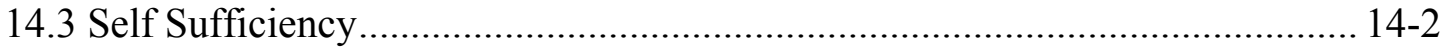

14.4 Business Plan Outline ……………........................................................ 14-3

Appendices

Appendix A. Bio-Fuel Specifications

Appendix B. Electrical Interconnections

Appendix C. Base Case Cash Flows

Appendix D. Legal Analysis

List of Tables

Table 4-2. Annual Demand and Energy Forecast......................................................... 4-3

Table 5-1. US DOE Classes of Wind Power. ………………................................... 5-5

Table 5-2. Wind Technology Characteristics. …………......................................... 5-7

Table 5-4. Solar Thermal Technology Characteristics. ............................................. 5-20

Table 5-5. Solar PV Technology Characteristics..................................................... 5-24

Table 5-6. Anaerobic Digestion Technology Characteristics..................................... 5-32

Table 5-7. Reciprocating Engine Technology Characteristics ..................................... 5-35

Table 5-8. Simple Cycle Combustion Turbine Technology Characteristics................ 5-37

Table 5-9. Microturbine Technology Characteristics................................................ 5-39

Table 5-10. Fuel Cell Technology Characteristics ................................................... 5-41

Table 7-1. Severance Scenario 1 Cost Breakdown and Estimate ..................................... 7-2 
Table 7-2. Severance Cost Breakdown and Estimates................................................. 7-3

Table 7-3. Severance Scenario 3 Cost Breakdown and Estimates................................. 7-4

Table 13-1. Net Metering Base Case Input Assumptions........................................ 13-2

Table 13-2. Model Input Assumptions. ................................................................ 13-4

\section{List of Figures}

Figure 1-1. Levelized Cost Results ....................................................................... 1-4

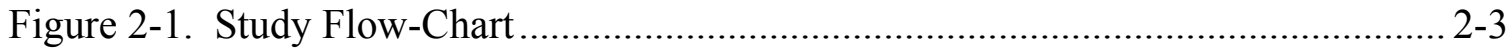

Figure 4-2. Daily Average of Hourly Viejas Energy Usage ...................................... 4-2

Figure 5-3. A small wind farm in Hawaii .............................................................. 5-2

Figure 5-4. The Palmdale Water District Net Metered Wind Turbine. ........................... 5-2

Figure 5-5. Close up of the California Wind Map Around Viejas................................ 5-6

Figure 5-6. Location of Wind Monitoring Equipment at Viejas. ................................. 5-8

Figure 5-7. Wind Rose for Casino Site................................................................. 5-11

Figure 5-8. Power Production by Time of Day...................................................... 5-12

Figure 5-9. Monthly Power Output..................................................................... 5-12

Figure 5-10. Casino Wind Speed Distribution...................................................... 5-13

Figure 5-11. Wind Resource Gradient, Viejas and Capitan Grande ............................ 5-15

Figure 5-12. Wind Resource Gradient, Viejas Valley Floor. .................................... 5-16

Figure 5-13. Parabolic Trough Field (Source: Union of Concerned Scientists)........... 5-17

Figure 5-14. Solar Two Central Receiver Installation ............................................ 5-17

Figure 5-15. Parabolic Dish Receiver (Source: Stirling Energy Systems)................. 5-19

Figure 5-16. Photovoltaic Solar Panel Installation................................................... 5-22

Figure 5-17. Pole Mounted Two Axis Tracking PV Array ....................................... 5-25

Figure 5-18. Parking Shade PV System. ........................................................... 5-26

Figure 5-19. $500 \mathrm{~m}^{3}$ Digester Treating Manure from a 10,000 Pig Farm in China...... 5-31

Figure 5-20. Engine Generator (Source: Caterpillar Corporation)............................. 5-34

Figure 5-21. Combustion Turbine Section (Source: Langston)................................. 5-35

Figure 5-22. Microturbine Cutaway View (Source: Capstone Turbine Corporation.). 5-38

Figure 5-23. 200 kW Fuel Cell (Source: UTC Fuel Cells)...................................... 5-40

Figure 10-1. Optimization Process ............................................................... 10-1

Figure 10-2. Levelized Cost Results .................................................................. 10-4

Figure 13-1. 10 Year Net Metering Net Present Value (NPV).................................. 13-3

Figure 13-2. 10 Year Utility Net Present Value (NPV) ........................................... 13-5 


\subsection{Executive Summary}

The purpose of this study is to investigate the feasibility of Renewable Energy Development on the lands of the Viejas Band of the Kumeyaay Indian Nation. In addition, the study will investigate the feasibility of forming a renewable energy based tribal utility. Viejas contracted with Black \& Veatch and Fredericks, Pelcyger \& Hester, LLC to assist in the development of a feasibility study to ascertain the economics and operational factors of forming an electric and water utility. This report is the result of the investigation conducted by Black \& Veatch, with input from Viejas Tribal Government. Fredericks, Pelcyger \& Hester, LLC performed Legal Analysis for the investigation. The results of the Legal Analysis are included as Appendix D to this report.

\subsection{Strategic Options}

Net metering is an arrangement with SDG\&E where renewable generation sources on Viejas property feed through the existing electrical meters. Each meter is only billed for the net energy consumed over a one year period. California's net metering law allows up to $1 \mathrm{MW}$ of renewable generation per meter to be placed on a net metering rate. Any generation in excess of consumption is forfeit. One approach to integrating renewable energy into the Viejas energy mix would be to leave the existing structure and relationship with SDG\&E in place and simply net meter renewable generation on the reservation.

Use of net metering would not exclude formation of a utility at a later date. Generation assets could be built up under net metering agreements with SDG\&E until such time as utility formation would be implemented. Net metering would allow Viejas to gain operational experience through management of net metering projects prior to formation of an electric utility. The Self Generation Incentive Program (SGIP) in California gives the Net Metering arrangement a significant economic advantage as compared to other renewable alternatives.

Another approach to self generation would be formation of a separate utility. The tribal utility would have a wheeling agreement with SDG\&E and power purchase agreements with energy suppliers. The tribal utility would likely operate most of the onreservation generation. By interacting with the grid, a Viejas utility is not required to produce all of the energy needed by reservation loads moment by moment.

A disadvantage of forming an independent utility is that it is not possible to take advantage of the California incentive programs mentioned in the net metering section. Furthermore, by interacting with the grid, Viejas would still be vulnerable to grid outages 
Viejas Tribal Government

Renewable Energy Development on Tribal

Lands of Viejas Study

1.0 Executive Summary

and, depending on the type of power purchase agreement, vulnerable to price fluctuations.

A third approach for self generation would included establishing a tribal utility that would be capable of providing all generation needs independent of the outside grid. A connection would likely still be in place, but an outage or a cost of energy increase on the grid would not necessarily translate into either an outage or dramatically increased cost of energy on the reservation.

A larger investment with lower return would be required to meet the self sufficiency goal of this scenario as compared to the interactive utility scenario. In addition to power quality equipment reliability would require redundant generation. Furthermore the generation profile would, by necessity, be heavy on firm or dispatchable generation, such as thermal generators (fossil or renewable fueled), as opposed to the variable energy sources such as solar and wind, unless significant energy storage is added.

\subsection{Energy Profile}

Hourly load data for the year 2003 was acquired for Viejas' large customers from SDG\&E. This data was used to generate an hourly load profile for these customers located within Viejas land. This hourly load profile is an important assumption used in the generation optimization model, and serves as the basis for dispatching generation using Black \& Veatch's production cost model, POWRPRO.

For residential customers, assumptions were developed by applying hourly residential load profiles for a comparable California utility to the number of residential customers on Viejas land.

The total energy used in this report's analysis is $24,018,539 \mathrm{kWh}$ for 2005 . The annual escalation of energy is assumed to be $1.70 \%$. A peak demand of $5,217 \mathrm{~kW}$ is assumed for 2005 , with an annual escalation of $1.70 \%$.

\subsection{Renewable Alternatives}

The following list of renewable generation alternatives was evaluated in this feasibility study. Detailed assumptions for each technology type including unit size, operating characteristics and cost characteristics are documented in Section 5.0.

- Wind

- Solar

- Bio-fuels

- Cogeneration 


\subsection{Other Issues}

In addition to the renewable generation alternatives, this study also investigates the following:

- The study investigated Energy Storage Technology options and Load Management alternatives for Viejas Tribal Government. These options are discussed in detail in Section 6.0.

- Electrical Interconnection Options for connection to the transmission grid are detailed in Section 7.0.

- Distribution System assumptions are detailed in Section 8.0.

- An Environmental Assessment is detailed in Section 11.0.

- A Tribal Benefit Assessment is detailed in Section 12.0.

- A Business Plan is discussed in Section 14.0.

\subsection{Legal}

Fredericks, Pelcyger \& Hester, LLC performed the Legal Analysis for the investigation. The results of the Legal Analysis are included as Appendix D to this report.

\subsection{Generation Mix Optimization}

A primary output of the Generation Mix Optimization process is a levelized cost comparison of the available renewable technologies. Figure 1-1 shows the range of likely Levelized Cost for each technology. A description of the Optimization approach is found in Section 10.0. Generation technology assumptions are detailed in Sections 5.0 and 6.0. 


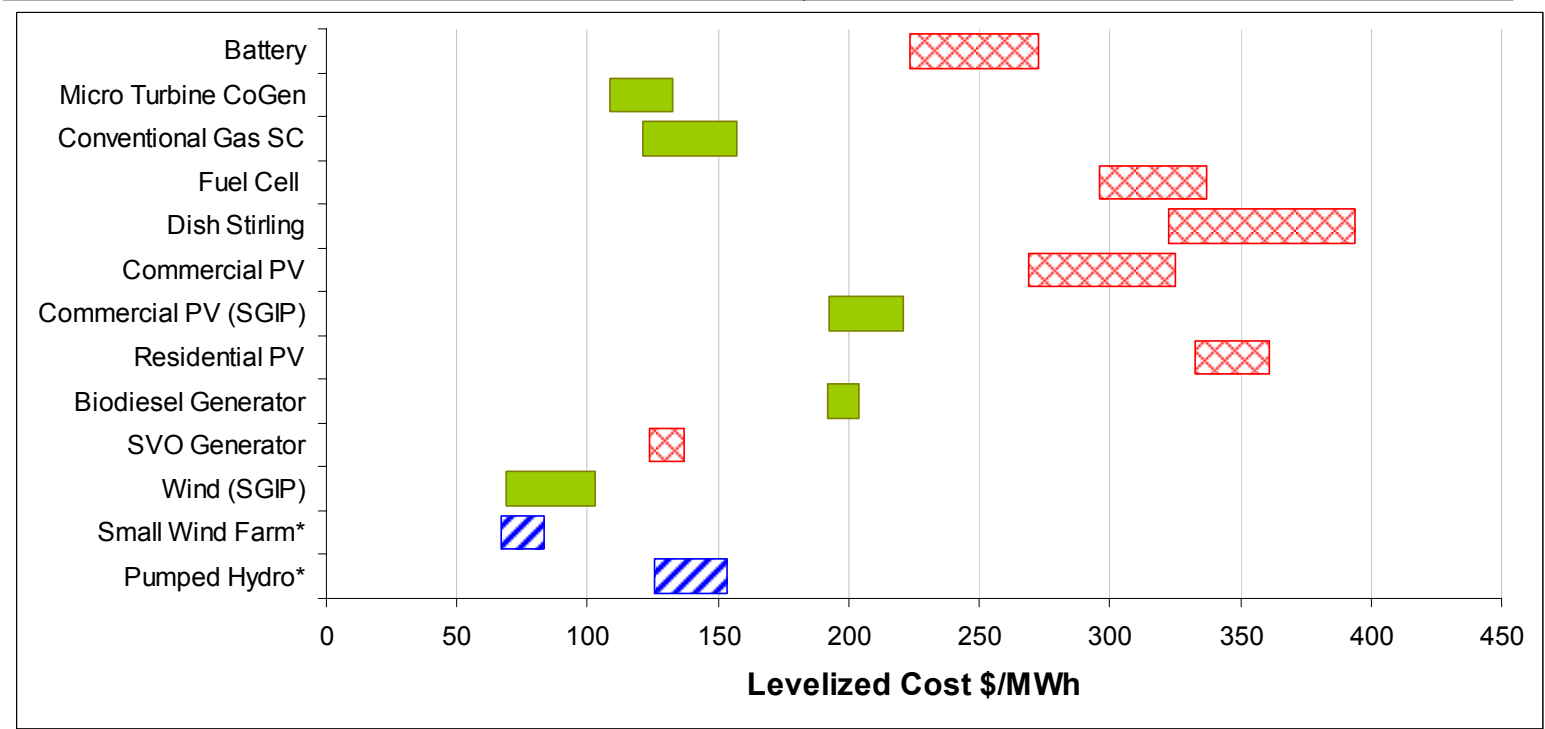

Considered in Optimization Model

Not Evaluated in Optimization Model

Considered for Stand Alone Utility Scenario Only

Figure 1-1. Levelized Cost Results

* The assumptions used for the Small Wind Farm and Pumped Hydro are dependent on both technologies being installed on the El Capitan Reservation.

In Figure 1-1, the levelized cost of the technologies highlighted in checkered red are uneconomic in comparison to the other options, as well as in comparison to the rates Viejas is currently paying for electricity. Therefore, these options were not evaluated further in the optimization process. Section 10.0 discusses the results in detail.

\subsection{Economics}

\subsubsection{Net Metering Planning Scenario}

The results of the Net Metering Planning Scenario analysis indicate that of the three scenarios, the option to install three $1 \mathrm{MW}$ wind turbines for net metering against Viejas' largest three meters has the highest 10 year Net Present Value (NPV). Under this scenario's Base Case, the 10-year cash flow analysis yields an NPV of $\$ 651,000$.

While the base case analysis for the three turbine scenario yields the largest NPV, Black \& Veatch notes that the policies governing both net metering and the SGIP program do have limits to what can be done at a single site or by a single owner. How these rules apply to these three meters was not specifically analyzed. The study assumes 
Viejas Tribal Government

Renewable Energy Development on Tribal

Lands of Viejas Study

1.0 Executive Summary

all three turbines receive the SGIP capital cost credit. The three turbine scenario should be considered contingent on meeting the regulatory requirements governing the program.

Section 13.2 includes a sensitivity analysis of key risk factors for the Net Metering Base Case scenario.

\subsubsection{Interconnected Utility Planning Scenario}

The 10 year net present value cash flow analysis shows that for the base case assumptions used, the formation of an electric utility is not economically viable. The base case scenario for the economic assessment assumes no renewable generation is installed by Viejas. For the interconnected utility planning scenario, the base case yields the most attractive 10 year NPV when compared to the renewable generation alternatives. The 10 year NPV for this base case is negative $\$ 1,929,000$.

Section 13.2 includes a sensitivity analysis of key risk factors for the Interconnected Utility Base Case scenario.

\subsection{Conclusions}

The Economic Analyses performed indicate that should Viejas become eligible for California's SGIP program, a Net Metering Wind Turbine Installation would be feasible under the base case assumptions. The sensitivity analysis indicates that wind turbine capacity factor is the largest driver of 10 year NPV for this planning scenario. Therefore Viejas should continue to monitor wind speeds via one or both of its anemometers.

The Interconnected Utility planning scenario economic analysis indicates that formation of a tribal utility would not be feasible under the base case assumptions. The top drivers for this scenario include the regulatory risk of reconfiguration costs, as well as market factors such as power supply cost. The sensitivity analysis indicates that annual average supply costs of \$59/MWh (in year 2005 dollars) or less would yield a positive 10 year NPV for the interconnected utility base case.

California's Self Generation Incentive Program (SGIP) is one of the primary drivers for wind to be an economically viable renewable generation option for Viejas. It will be important for Viejas to apply now for the SGIP in order to maximize its chances of obtaining any available funds from the program. 


\subsection{Introduction}

\subsection{Objective}

The objective of this study is to investigate the feasibility of Renewable Energy Development on the lands of the Viejas Band of the Kumeyaay Indian Nation. In addition, the study will investigate the feasibility of forming a renewable energy based tribal utility.

Specific objectives of the study include:

- Assessment of renewable energy resources and technology (solar, wind, biomass) specific to the reservation

- Development of a detailed reservation load profile

- Assessment of energy storage and load management opportunities

- Analysis of electrical interconnection options

- Audit of the existing distribution system

- Legal analysis of the regulatory implications of forming a tribal utility

- Optimization study to determine the most cost effective generation and load management mix

- Assessment of environmental issues

- Assessment of tribal benefits

- Economic assessment of the potential renewable energy utility

- Development of a business plan for the renewable tribal utility aligned with overall tribal goals

\subsection{Background}

The Viejas Tribal Government selected Black \& Veatch to perform a study to investigate the feasibility of forming a renewable energy based electric utility company as Viejas continues to investigate electrical generation and energy supply alternatives. Currently, Viejas receives all of its power and natural gas from SDG\&E. Market volatility in the California market has affected almost all of the State's retail customers in the recent past. Viejas is no different in that it has been subjected to price increases for its electricity. Thus, Viejas has begun to seek out alternative sources of renewable energy. 
Two circuits feed the reservation distribution system, and no other distribution circuits intersect the Reservation's boundaries. Ample space exists within the boundaries to support self-generation if pursued, and sufficient space exists for normal residential growth. The primary obstacle into forming an electric utility will be the cost and arrangements to physically deliver electricity to the Viejas distribution system. The difficulty stems from the fact that the Alpine substation is approximately eight miles away and distance complicates the delivery arrangements Viejas will have to make for its electricity supply.

\subsection{Approach}

The project approach and tasks involved are shown in Figure 2-1 below. Generally, the study investigates which renewable technologies are optimal for the environment of the Viejas Reservation. The study is based on a projected load profile of the reservation and renewable resource availability and technology characteristics. The POWROPT generation mix optimization model determines the best mix of resources to minimize cost while ensuring high reliability of supply. Section 10.0 describes the optimization process and models used in detail. Candidate technologies include solar, wind, biogas, biodiesel, and demand side management strategies. These alternatives are discussed in detail in sections 5.0 and 6.0. 


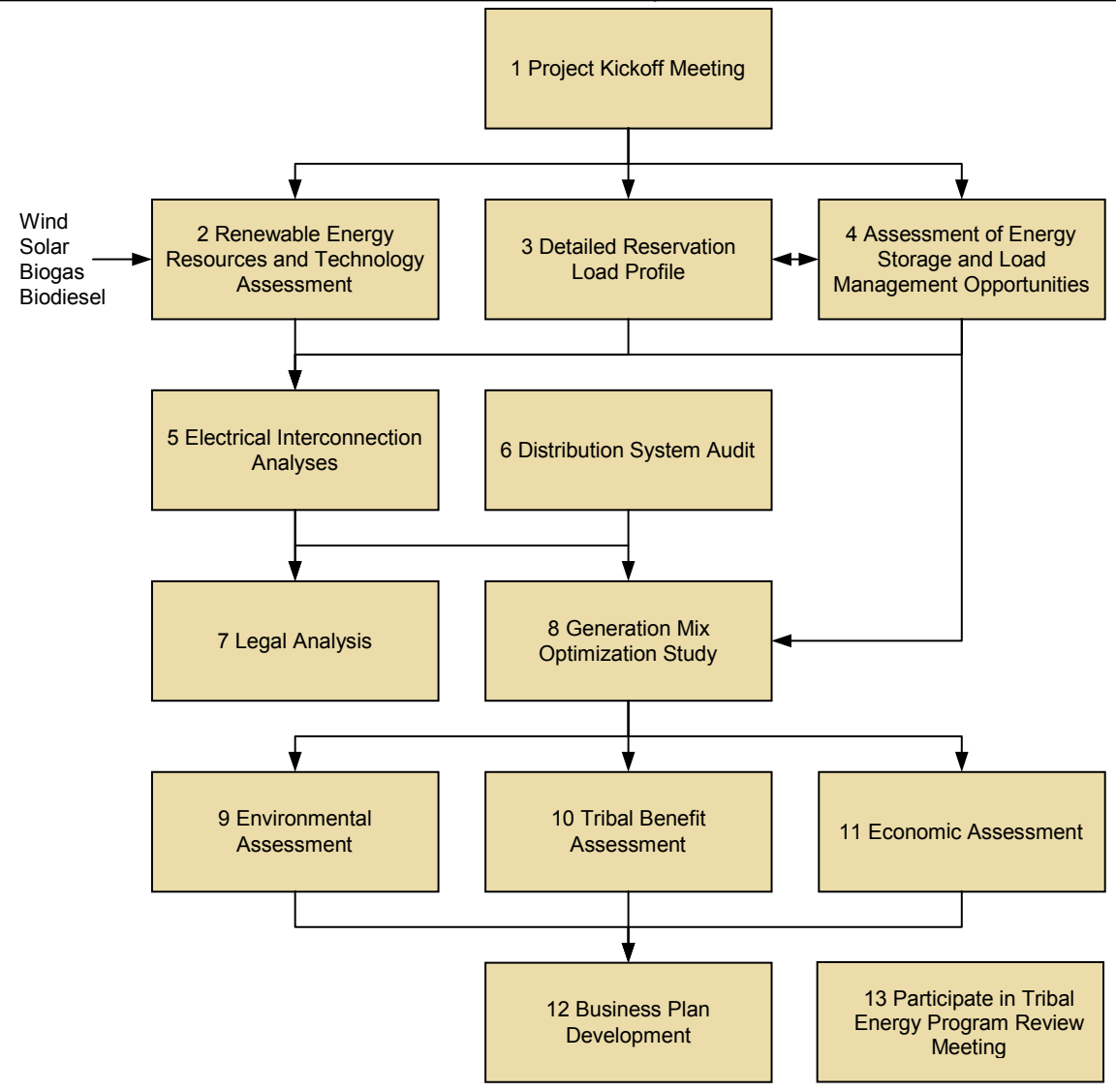

Figure 2-1. Study Flow-Chart

The study investigates three other primary areas: (1) a distribution system audit to determine the value of the existing utility electric system, (2) analyses of the various interconnection options, and (3) a legal review to verify the legitimacy of the proposed utility. Based on these investigations, the discounted cash flow analyses are performed to gauge the economic viability of the various options. In addition, environmental and tribal benefit studies are conducted, and an outline of a business plan to implement potential initiatives is presented.

Black \& Veatch used a discounted cash flow methodology to evaluate the financial feasibility of forming an electric utility. This methodology was used because comparison between different scenarios is relatively easier to perform and because it provides an estimate of the expected revenue streams. A detailed analysis, including but not limited to actual installed equipment and original cost information, is required to determine the actual cost of specific report items. 


\section{Viejas Tribal Government \\ Renewable Energy Development on Tribal \\ Lands of Viejas Study}

2.0 Introduction

This report is a feasibility analysis for Viejas that includes the best market information known at this time. The optimization study and economic analysis sections use energy supply costs that are general estimates provided to Viejas to give an indication of the magnitude of these costs. Therefore, many of the financial and engineering assumptions will need to be studied further to develop specific detailed information. 


\subsection{Strategic Options}

Viejas has several options in gaining more energy self sufficiency and economy. The options presented below cover the range of possibility. These options may be seen as independent options or as stages, one leading to the other in a long term strategy.

\subsection{Net Metering on Individual Accounts}

Net metering is an arrangement with SDG\&E where renewable generation sources on Viejas property feed through the existing electrical meters. Each meter is only billed for the net energy consumed over a one year period. California's net metering law allows up to $1 \mathrm{MW}$ of renewable generation per meter to be placed on a net metering rate. Any generation in excess of consumption is forfeit.

One approach to integrating renewable energy into the Viejas energy mix would be to leave the existing structure and relationship with SDG\&E in place and simply net meter renewable generation on the reservation. Renewable generation projects could be scaled to approximately match the annual energy consumption at the meter to which they were interconnected. On a project by project basis it can be decided if a project is desirable based on economic and other factors.

The biggest advantage of a net metering scenario is that SDG\&E, in affect, acts like a perfect battery, storing and releasing energy with zero losses. Thus the need for on site energy storage or supplemental generation on site to supply all loads at all times is completely avoided. Another advantage is that at Viejas both solar and wind resources are greatest in the afternoons when power is most valuable. Thus by picking a favorable time-of-day rate, Viejas would be able to gain more than one-to-one credit for excess energy produced in the afternoon and consumed at night. Furthermore, California has two strong incentives for projects under $1 \mathrm{MW}$ capacity, the California Energy Commission buy down program for projects under $30 \mathrm{~kW}$ and the California Public Utility Commission Self Generation Incentive Program (SGIP). Viejas may be able to be take advantage of these incentives for greater than $1 \mathrm{MW}$ worth of projects by applying for them each separately on a different account. These incentives would not be available to an independent Viejas utility. It should be noted that the Self Generation Incentive Program (SGIP), which is for projects over $30 \mathrm{kw}$, is very heavily subscribed to and there is currently a waiting list. Availability of this incentive has been assumed for these analyses but its actual availability is not certain and is subject to future funding levels and rule changes. 
Generation projects which do not feed electricity back into the grid do not require a net metering agreement. Thus smaller projects, sized below the minimum load of the meter, will not have to meet net metering requirements. This type of project is included in discussions of "net metering" throughout the report since it performs the same function of reducing energy costs behind a meter.

Disadvantages of the net metering approach are mainly associated with the fragmented implementation required. Excess generation at one site does not compensate for deficient generation at another. Furthermore, net metering limits siting of projects to the site of the meter used, which may not be ideal from a resource or space perspective. Integration of diverse elements of generation, load shifting and cogeneration is constrained by the 'walls' between individual meters. Although net metering does provide some energy security because consumption is reduced, Viejas does not have control over the electrical system as a whole and would still be quite dependent on SDG\&E.

Use of net metering would not exclude formation of a utility at a later date. Generation assets could be built up under net metering agreements with SDG\&E until such time as utility formation would be implemented. Net metering would allow Viejas to gain operational experience through management of net metering projects prior to formation of an electric utility.

\subsection{Tribal Utility Interactive with the Grid}

A more aggressive approach (or a second stage) to self generation would be formation of a separate utility. The tribal utility would have a wheeling agreement with SDG\&E and power purchase agreements with energy suppliers. The tribal utility would likely operate most of the on-reservation generation.

Forming an independent utility gives Viejas the ability to select energy suppliers (and customers for excess energy). Coordination of reservation-wide load shifting, generation, and cogeneration activities is greatly facilitated by having all loads behind one 'door' to the grid at large. It becomes more desirable and effective as an independent utility to integrate energy storage or dispatchable generation to avoid capacity charges and minimize on peak electricity usage. By interacting with the grid, a Viejas utility is not required to produce all of the energy needed by reservation loads moment by moment. Generation, storage, and load management projects can be selected using whatever economic or other criteria deemed necessary without the burden of being required to meet loads with on site resources.

A disadvantage of forming an independent utility is that it is not possible to take advantage of the two California incentive programs mentioned in the net metering 
section. Furthermore, by interacting with the grid, Viejas would still be vulnerable to grid outages and, depending on the type of power purchase agreement, vulnerable to price fluctuations.

\subsection{Tribal Utility Independent of the Grid}

If energy independence is a strong goal for Viejas, a utility could be established that would be capable of providing all generation needs independent of the outside grid. A connection would likely still be in place, but an outage or a cost of energy increase on the grid would not translate into either outage or dramatically increased cost of energy on the reservation.

In this ambitious scenario, sufficient generation, storage, and load diverting capability would need to be in place to balance generation and loads on site in absence of the support of the grid. Additional power quality equipment would likely be required. The main advantage of this scenario is self sufficiency, security, and self reliance. Viejas could still maintain the ability to interact with the grid to buy and sell power, but this would not be required.

A bigger investment with lower return would be required to meet the self sufficiency goal of this scenario as compared to the interactive utility scenario. In addition to power quality equipment reliability would require redundant generation. Furthermore the generation profile would, by necessity, be heavy on firm or dispatchable generation, such as thermal generators (fossil or renewable fueled), as opposed to the variable energy sources such as solar and wind, unless significant energy storage is added. 


\subsection{Detailed Viejas Energy Profile}

\subsection{Customer Load Profile}

The number of customers that the Tribal Utility would potentially provide electric services to was estimated using customer data provided by the Viejas Tribal Government. Table 4-1 is a summary of the Tribal Utility's customer breakdown.

\begin{tabular}{|l|r|}
\hline \multicolumn{1}{|c|}{ Number of Customers } & \\
\hline Residential & 175 \\
\hline Percent of Total & $61 \%$ \\
\hline & 50 \\
\hline Casino & $18 \%$ \\
\hline Percent of Total & 10 \\
\hline & $4 \%$ \\
\hline Tribal Offices/Facilities & \\
\hline Percent of Total & 50 \\
\hline & $17 \%$ \\
\hline Retail Outlet & \\
\hline Percent of Total & 285 \\
\hline & \\
\hline Total & \\
\hline
\end{tabular}

Table 4-1. Customer Breakdown.

Due to the resistance in electrical power transmission and distribution lines, a certain amount of power is lost from a generating facility to where the power is finally consumed. The annual loss factor is assumed to be 6.18 percent. This figure is in-line with industry averages. Viejas will have to account for these losses and purchase additional power at the transmission grid to ensure adequate power for its customers. The total energy used in this report's analysis is $24,018,539 \mathrm{kWh}$ for 2005 . The annual escalation of energy is assumed to be $1.70 \%$.

Hourly load data for the year 2003 was acquired for Viejas' large customers from SDG\&E. This data was used to generate an hourly load profile for these customers located within Viejas land. For residential customers, assumptions were developed by applying hourly residential load profiles for a comparable California utility to the number of residential customers on Viejas land. Figure 4-1 shows the average hourly energy usage for 2003 for the aggregate Viejas load. 


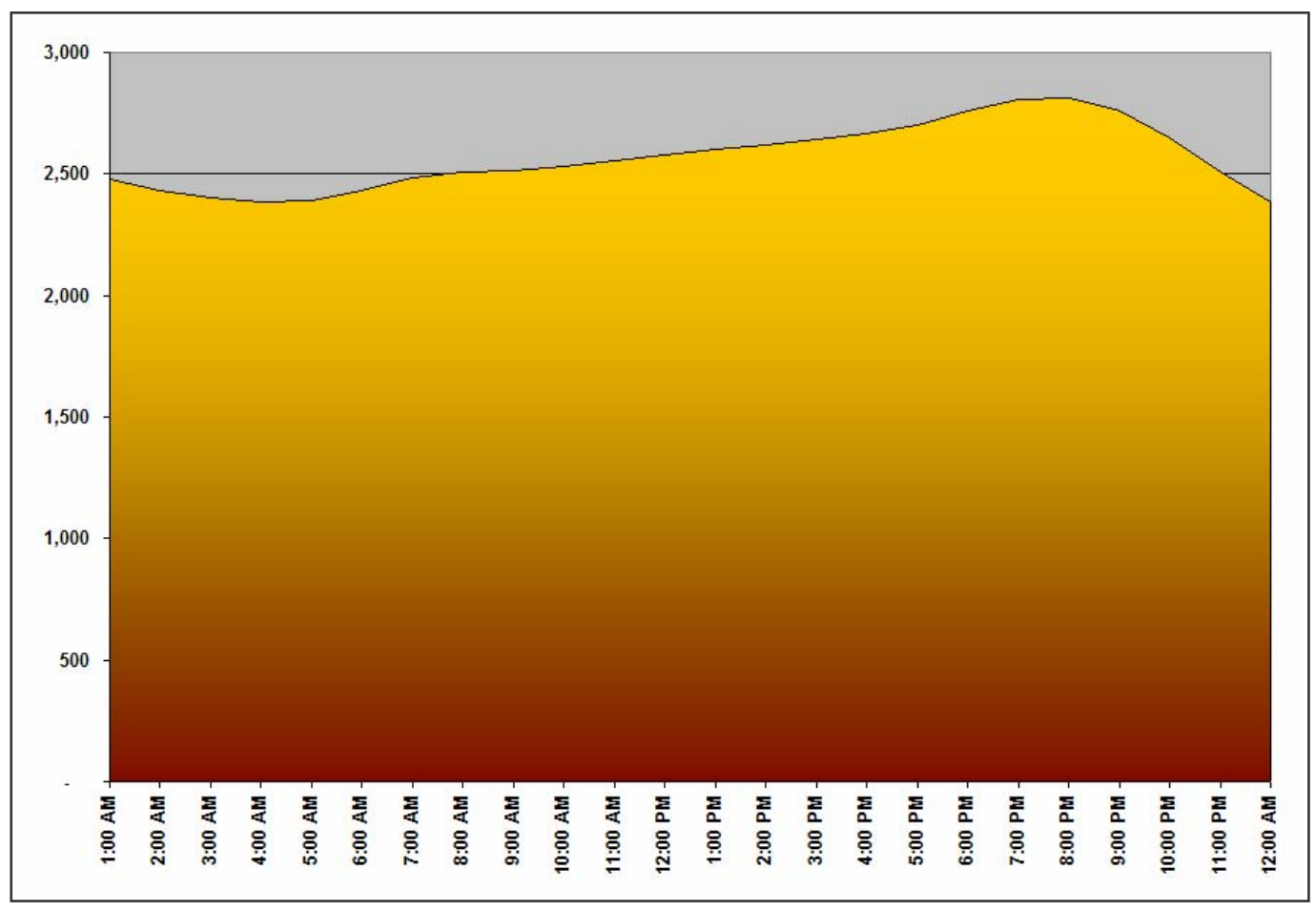

Figure 4-1. Daily Average of Hourly Viejas Energy Usage

\subsection{Projected Peak Demand}

Another key element in determining the Tribal Utility's cost of power is determining the peak electric demand that occurs on the Tribal Utility's system. Black \& Veatch has estimated the Tribal Utility's annual energy sales and the system load factor using results from the Energy Assessment Study performed by Black \& Veatch in 2002. Table 4-2 shows the forecasted Peak Demand and Annual Energy Usage for the years 2005 through 2026. Peak Demand and Annual Energy are assumed to escalate at $1.70 \%$ per year. 
Table 4-2. Annual Demand and Energy Forecast.

\begin{tabular}{|c|c|c|}
\hline Year & Peak Demand & Annual Energy Usage \\
\hline 2005 & 5,217 & $24,018,539$ \\
\hline 2006 & 5,306 & $24,426,855$ \\
\hline 2007 & 5,396 & $24,842,111$ \\
\hline 2008 & 5,488 & $25,264,427$ \\
\hline 2009 & 5,581 & $25,693,922$ \\
\hline 2010 & 5,676 & $26,130,719$ \\
\hline 2011 & 5,772 & $26,574,941$ \\
\hline 2012 & 5,871 & $27,026,715$ \\
\hline 2013 & 5,970 & $27,486,169$ \\
\hline 2014 & 6,072 & $27,953,434$ \\
\hline 2015 & 6,175 & $28,428,643$ \\
\hline 2016 & 6,280 & $28,911,929$ \\
\hline 2017 & 6,387 & $29,403,432$ \\
\hline 2018 & 6,495 & $29,903,291$ \\
\hline 2019 & 6,606 & $30,411,647$ \\
\hline 2020 & 6,718 & $30,928,645$ \\
\hline 2021 & 6,832 & $31,454,432$ \\
\hline 2022 & 6,949 & $31,989,157$ \\
\hline 2023 & 7,067 & $32,532,973$ \\
\hline 2024 & 7,187 & $33,086,033$ \\
\hline 2025 & 7,309 & $33,648,496$ \\
\hline 2026 & 7,433 & $34,220,520$ \\
\hline
\end{tabular}

\subsection{Hourly Load Profile}

Hourly load data for the year 2003 was acquired for Viejas' large customers from SDG\&E. This data was used to generate an hourly load profile for the customers located within Viejas land. Figure 4-1 shows the daily average energy usage by hour for 2003. This hourly load profile is an important assumption used in the generation optimization model, and serves as the basis for dispatching generation using Black \& Veatch's production cost model, POWRPRO. The optimization model and POWRPRO are described in Section 10.0. 


\subsection{Renewable Energy Alternatives}

\subsection{Wind}

Wind power systems convert the movement of the air to power by means of a rotating turbine and a generator. Wind power has been the fastest growing energy technology of the last decade. It has realized around 30 percent annual growth in worldwide capacity for the last five years. Cumulative worldwide wind capacity is now estimated to be more than 39,000 MW. Europe now leads in wind energy, with more than 28,000 MW installed; Germany, Denmark, and Spain are the leading European countries. Installations of wind turbines have outpaced all other energy technologies in Europe for the past two years.

In the US, the American Wind Energy Association (AWEA) has noted that wind turbine capacity exceeded 6,000 MW at the start of 2004. The booming US wind market has been driven by a combination of growing state mandates, such as that in place for California, and the production tax credit (PTC), which provides a 10 -year $1.8 \mathrm{cent} / \mathrm{kWh}$ incentive for electricity produced from wind. The PTC is active through the end of the year 2007. Over 2,000 MW are expected to be installed in 2005.

Typical utility-scale wind energy systems consist of multiple wind turbines that range in size from $0.6 \mathrm{MW}$ to $2 \mathrm{MW}$. Typical wind energy system installations may be as small as 0.6 MW or as large as $300 \mathrm{MW}$. Single and small groupings of turbines are common in Denmark and Germany whereas installation of large wind farms is more typical in the United States. However, use of single turbines is increasingly common in the United States for powering schools, farms, factories, water treatment plants, and other distributed loads. At the other end of the spectrum, off-shore wind energy projects are now being planned, which is encouraging the development of both larger turbines (up to $5 \mathrm{MW}$ ) and larger wind farms.

Wind is an intermittent resource with average capacity factors usually ranging from 25 to 40 percent. Capacity factor is the percent of energy produced in a year compared to what the generator would produce if it were running at full output all year. The capacity factor of an installation depends on the wind regime in the area and energy capture characteristics of the wind turbine. Capacity factor directly impacts economic performance, thus reasonably strong wind sites are a must for cost effective installations. 


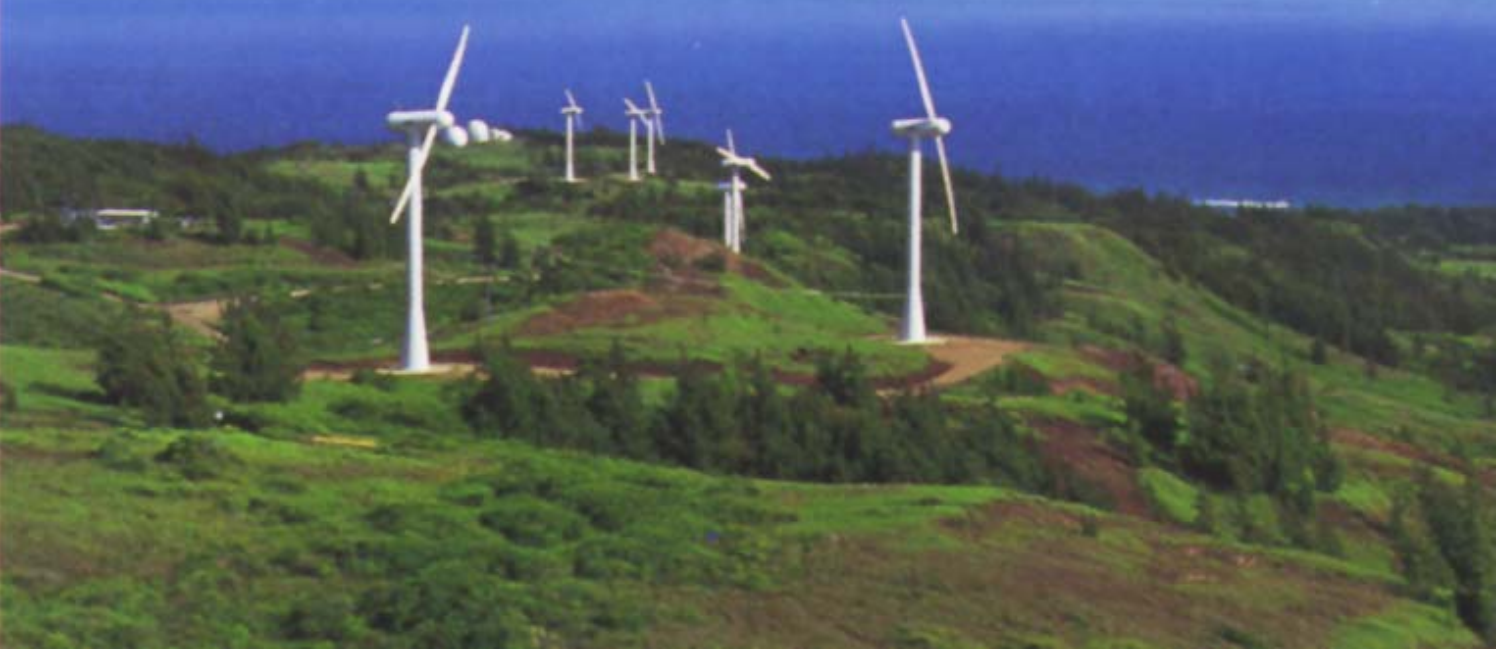

Figure 5-2. A small wind farm in Hawaii

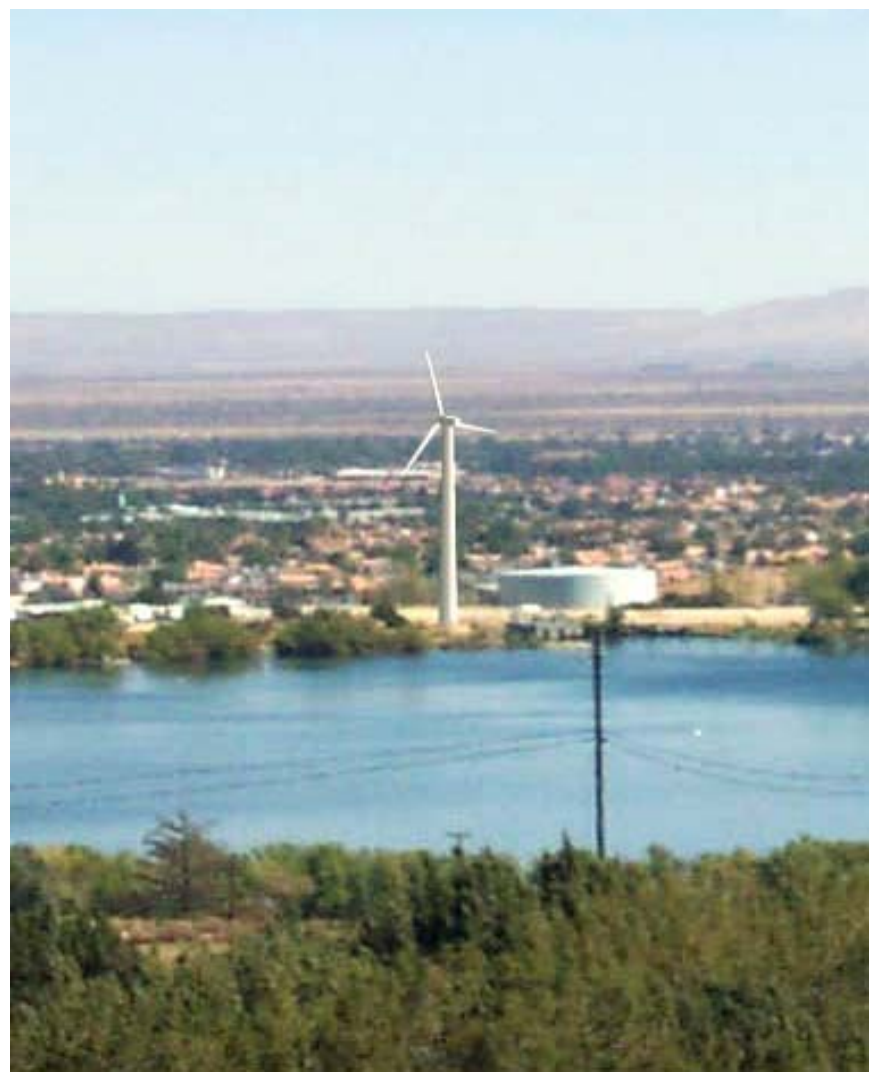

Figure 5-3. The Palmdale Water District Net Metered Wind Turbine. 
Because wind is intermittent it cannot be relied upon as firm capacity. To provide a dependable resource, wind energy systems may be coupled with some type of energy storage or a fossil energy source to provide power when required by the load. This adds considerable expense and is not usually done on a without special circumstances. Numerous studies have shown that, within a typical utility, relatively low levels of wind penetration $5-15 \%$ will not necessitate significant additional backup generation or other system improvements. Efforts are currently underway by research agencies to forecast wind speeds more accurately, thereby increasing confidence in wind power as a generation resource and dependability in utility dispatching.

Wind is created primarily by global temperature fluctuations and thermal interactions between land, sea, and air. Wind energy systems convert the power of moving air into electricity. Aerodynamic forces act on the rotor to convert the linear motion of the wind stream into the rotational motion needed to turn an electrical generator. The available power in the kinetic energy of the wind is given by the relation:

$$
P=1 / 2 \rho A V^{3}
$$

where $\rho$ is the air density, $\mathrm{A}$ is the rotor area intercepting the wind, and $\mathrm{V}$ is the upstream wind velocity. Of these, wind velocity is most important. The cubic dependence of wind power on wind speed implies that energy output, and consequently the economics of a wind turbine installation, is highly sensitive to wind speed. A 50 percent change in velocity results in more than tripling available energy; thus wind speed is one of the most critical factors in determining wind energy generation. Wind power density is expressed in Watts per meter squared $\left(\mathrm{W} / \mathrm{m}^{2}\right)$ and incorporates the combined effects of the time variant wind speed and the dependence of wind power on both air density and cube of wind speed. The figures in this report show wind power density categorized by wind power class from 0-7.

Average wind speeds vary significantly geographically. Local factors such as high altitude, unobstructed terrain, lofty airflow height, and natural wind tunneling features cause some areas to have inherently higher wind speeds on average than others. Wind speed is affected by the height above ground level (AGL). Ideally, wind resources assessments are performed at the hub height of the candidate wind turbine (40 to $80 \mathrm{~m}$ ); however, if measurements at the actual hub height $(\mathrm{Z})$ are not available, wind speed (v) can be extrapolated from other measurement heights. The most common method is the following relation, known as the one-seventh power law: 


$$
\frac{v_{2}}{v_{1}}=\left(\frac{Z_{2}}{Z_{1}}\right)^{1 / 7} \text { or } \frac{P_{2}}{P_{1}}=\left(\frac{Z_{2}}{Z_{1}}\right)^{3 / 7}
$$

For example, based on the one-seventh power law, wind speed and wind power (P) at $30 \mathrm{~m}$ above the ground are respectively 17 and 60 percent greater than at $10 \mathrm{~m}$. Although a convenient approximation, the one-seventh power law has no theoretical basis. A custom power law can be applied to a specific site data by measuring wind speed at two or more different heights on the same tower and determining the wind sheer factor (s) for a specific site. Once a sheer factor is known for a site, wind speed can be scaled using the following equation:

$$
v_{2}=v_{1} *\left(\frac{Z_{2}}{Z_{1}}\right)^{S}
$$

The site-specific nature of the wind energy resource underscores the need for well-planned assessments. The one-seventh power law may be inadequate because it is only an approximation and the amount of wind energy available is strongly affected by the local terrain. If the wind sheer factor for a specific site is known, a more accurate power estimate can be made from non-hub height data. A thorough study of the wind at a particular site is advisable before installing wind turbines. Collecting data at multiple hub heights and locations allows for the optimum design and placement of individual turbines in large turbine arrays or on complex terrain. In this report, a wind sheer factor was estimated based on the local topography and measurements made at ten and twenty meters above ground level.

The site wind resource is of critical importance to a wind project because it is the fuel for the power plant. Wind generation suffers in notoriety because it is intermittent subject to the strength and consistency of the wind. Because of this, the best way to ensure a successful project is to collect as much data as possible and make informed decisions at every step of the project development. This data should be compared against historical data for the area for the longest possible time span that data can be obtained.

For the purposes of this study, the wind resource has been evaluated using Data collected at two sites on the reservation for a period of a year. The data from these sites did not correlate well with publicly available long term data from Campo, CA, Palm Springs, CA, nor any other nearby public data source. The Manzanita Band of the Kumeyaay tribe has been collecting wind data for several years for their own wind energy project. Black \& Veatch has contacted the Manzanita Band to obtain access to this data, however access has not yet been granted. 
Viejas Tribal Government

Renewable Energy Development on Tribal

Lands of Viejas Study

5.0 Renewable Energy Alternatives

\subsubsection{Resource Availability}

Wind speed increases significantly with height above ground, and wind turbine power output rises with the cube of wind speed, which makes small differences in wind speed very significant. As shown in Table 5-1 wind strength is rated on a scale from Class 1 to Class 7 . Wind speeds and power densities $\left(\mathrm{W} / \mathrm{m}^{2}\right)$ at a Class 1 site and at a 50 meter height can go as high as $5.5 \mathrm{~m} / \mathrm{s}$ and $200 \mathrm{~W} / \mathrm{m}^{2}$. In comparison, wind speeds and power densities at a Class 7 site and at the same hub height may be above $8.80 \mathrm{~m} / \mathrm{s}$ and approach $1000 \mathrm{~W} / \mathrm{m}^{2}$. Class 3 sites and higher are usually considered for wind project development, although possibly Class 2 sites also may be viable for self generation, depending on the cost of electricity.

Regardless of the existence of high resolution resource maps for some regions, a minimum of one-year of site data collection is typically required to determine if utilityscale wind energy is viable at a specific location. Wind speeds around the Viejas reservation from the California wind map data published by the National Renewable Energy Laboratory and prepared by Black \& Veatch can be seen in Figure 5-4. Wind map data is considered accurate to within one wind class.

\begin{tabular}{|c|c|c|}
\hline \multirow{2}{*}{ Wind Power Class } & \multicolumn{2}{|c|}{ "Height Above Ground: 50 m (164 ft) } \\
\hline & Wind Power Density, W/m² & Speed $^{* *} \mathrm{~m} / \mathrm{s}$ \\
\hline 1 & $0-200$ & $0-5.60$ \\
\hline 2 & $200-300$ & $5.60-6.40$ \\
\hline 3 & $300-400$ & $6.40-7.00$ \\
\hline 4 & $400-500$ & $7.00-7.50$ \\
\hline 5 & $500-600$ & $7.50-8.00$ \\
\hline 6 & $600-800$ & $8.00-8.80$ \\
\hline 7 & $800-2000$ & $8.80+$ \\
\hline \multicolumn{3}{|c|}{$\begin{array}{l}\text { * Vertical extrapolation of wind speed based on the } 1 / 7 \text { power law. } \\
\text { Mean wind speed is based on Rayleigh speed distribution of equivalent mean wind } \\
\text { power density. Wind speed is for standard sea-level conditions. To maintain the } \\
\text { same power density, wind speed must increase } 3 \% / 1000 \mathrm{~m}(5 \% / 5000 \mathrm{ft}) \text { elevation. }\end{array}$} \\
\hline
\end{tabular}




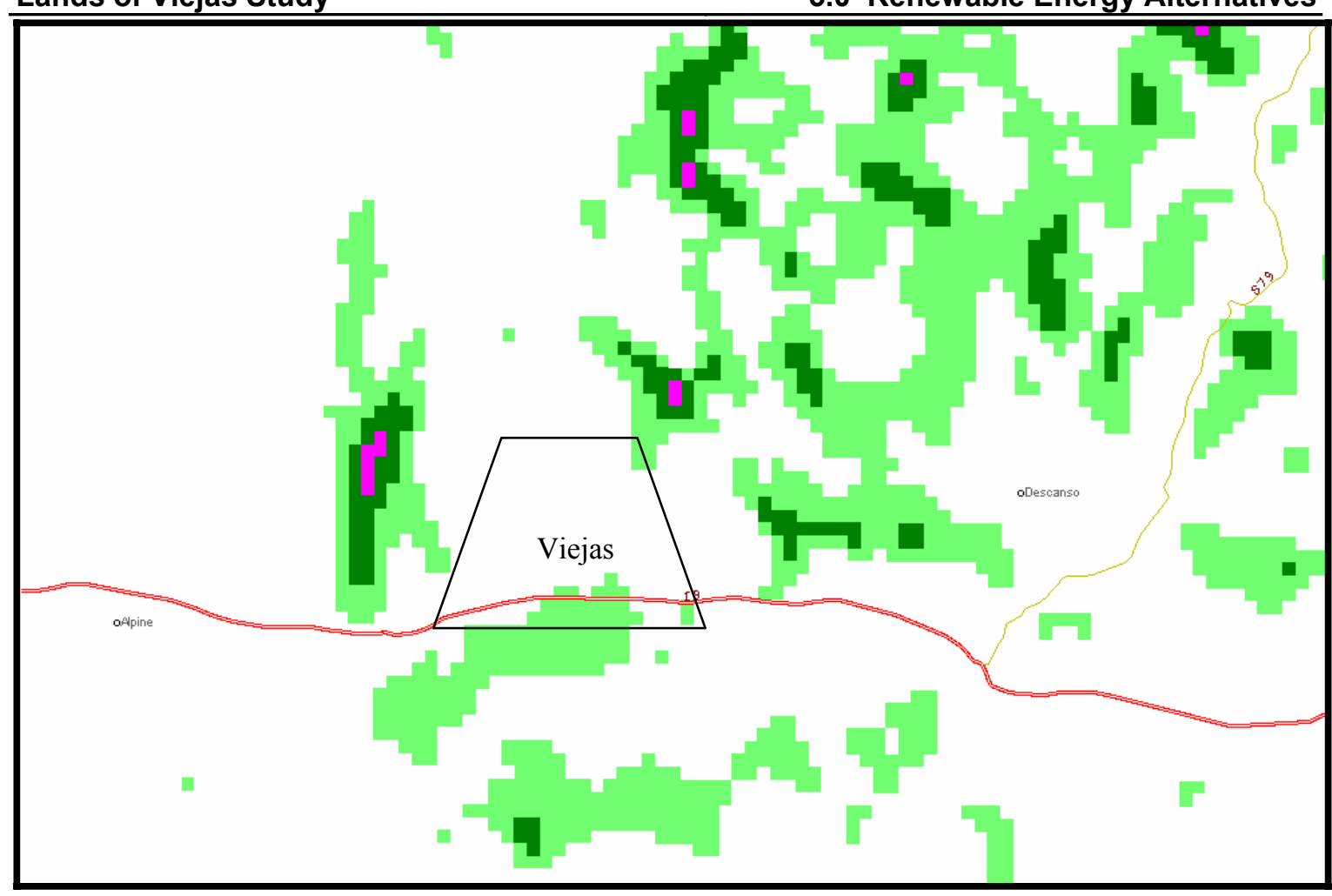

Figure 5-4. Close up of the California Wind Map Around Viejas.

Figure 5-4 Shows the wind map for California around the area of Viejas. Light green indicates Wind Class 2, dark green is Wind Class 3, and Fuchsia shows wind class 4.

\subsubsection{Cost and Performance Characteristics}

Table 5-2 provides typical characteristics for a $50 \mathrm{MW}$ wind farm and a single 1 MW turbine for distributed applications. Substantially higher costs are incurred by wind projects that require upgrades to transmission and distribution lines. Capacity factors for the two sample projects have been chosen to correlate with those expected for a wind farm on the Capitan Grande Reservation and a net metered turbine at the casino. 
Table 5-2. Wind Technology Characteristics.

\begin{tabular}{|c|c|c|}
\hline & Wind Farm & Distributed \\
\hline \multicolumn{3}{|l|}{ Performance } \\
\hline Typical Duty Cycle & As Available & As Available \\
\hline Net Plant Capacity, MW & 50 & 1 \\
\hline Capacity Factor, percent & $20-30$ & $8-13$ \\
\hline \multicolumn{3}{|l|}{ Economics } \\
\hline Capital Cost, $\$ / \mathrm{kW}$ & 1,600 & $700 *$ \\
\hline Fixed O\&M, \$/kW-yr & 15 & 18 \\
\hline Levelized Cost, \$/MWh & 70 & 90 \\
\hline \multicolumn{3}{|l|}{ Technology Status } \\
\hline Commercial Status & \multicolumn{2}{|c|}{ Commercial } \\
\hline Installed US Capacity, MW & \multicolumn{2}{|c|}{6,740} \\
\hline Viejas Potential & \multicolumn{2}{|c|}{ Fair } \\
\hline
\end{tabular}

Capital costs for new onshore wind projects have remained relatively stable for the past few years and have increased recently with the cost of steel. The greatest success in reducing cost of energy have been made by identifying and developing sites with better wind resources and improving turbine reliability. These both lead to improved capacity factors. The average capacity factor for all installed wind projects in the US has dramatically increased, from just 20 percent in 1998 to more than 30 percent in $2002{ }^{1}$

\subsubsection{Site Assessment / Selection}

Two sites were selected at Viejas for wind data collection. The sites are shown on the map in Figure 5-6. The site labeled Master was chosen due to its central location and plentiful open space for siting future wind turbines. The Master anemometer is intended to be the future reference site to correlate any future wind data collection sites and to collect long term data. The site labeled Casino was chosen as an alternate measurement point in a location selected to take advantage of any acceleration of wind into the Viejas valley. The Casino location would be a potential site for a single turbine interconnected with the Casino.

\footnotetext{
${ }^{1}$ Based on annual wind generation and capacity data from the Energy Information Administration's Renewable Energy Annual 2002.
} 


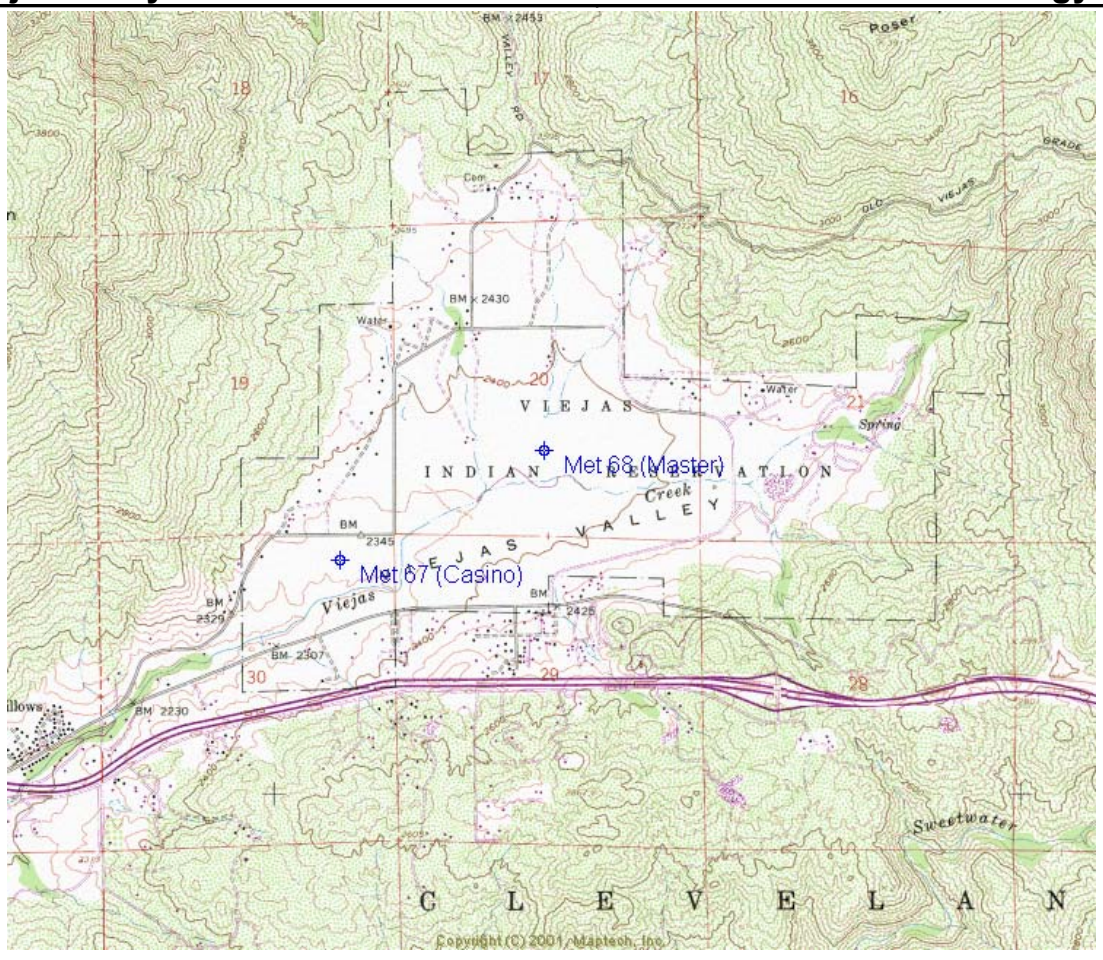

Figure 5-5. Location of Wind Monitoring Equipment at Viejas.

\subsubsection{Wind Data Collection}

Data was collected at both sites using an NRG 20 meter tower and an NRG 9200Pluss Data logger. Anemometers were placed at 10 and 20 meters above ground level, and wind direction was measured at 20 meters above ground level. Data was averaged in date-and-time-stamped ten-minute intervals. Data sticks were exchanged monthly and the data was uploaded in the Viejas Tribal Government public works office. Data was then emailed to Black \& Veatch, where it was conditioned and analyzed. This report uses data collected from 8:30 am March 3, 2004 till 8:20 am March 3, 2005. Data was missing for both sites simultaneously for a total of 62 days, primarily in November, December, and January. Data loss in November is likely due to a nearby lighting strike, disabling both data loggers. An attempt to fix the problem was made but Data from both loggers was lost in the last half of December. Additional data was lost while both loggers were in for repair in January. Data loss problems have continued at a less severe level and the cause is not understood at present. Where data was missing from only one site Black \& Veatch established correlation factors between the two sites and filled in the missing data using data from the site with good data.

Table 5-3 provides a catalogue of significant periods of lost data. 
Table 5-3. Missing Data

\begin{tabular}{|l|l|l|c|}
\hline Start Date & End Date & Data Capture & Days \\
\hline $3 / 3 / 048: 40$ & $4 / 29 / 043: 30$ & Good Data & 57 \\
\hline $4 / 29 / 043: 30$ & $5 / 5 / 0413: 10$ & Missing Data & 6 \\
\hline $5 / 5 / 0413: 10$ & $11 / 4 / 049: 10$ & Good Data & 183 \\
\hline $11 / 4 / 049: 10$ & $12 / 2 / 0417: 20$ & Missing Data, Possible Lightning Strike & 28 \\
\hline $12 / 2 / 0417: 20$ & $12 / 6 / 047: 20$ & Good Data & 4 \\
\hline $12 / 6 / 047: 20$ & $12 / 13 / 0414: 00$ & Master fills in Casino & 7 \\
\hline $12 / 13 / 0414: 00$ & $12 / 17 / 0411: 20$ & Good Data & 4 \\
\hline $12 / 17 / 0411: 20$ & $1 / 3 / 059: 10$ & Missing Data & 17 \\
\hline $1 / 3 / 059: 10$ & $1 / 7 / 058: 30$ & Master fills in Casino & 4 \\
\hline $1 / 7 / 058: 30$ & $1 / 20 / 0513: 10$ & Missing Data, Loggers in for repair. & 13 \\
\hline $1 / 20 / 0513: 10$ & $1 / 28 / 058: 40$ & Good Data & 8 \\
\hline $1 / 28 / 058: 40$ & $2 / 25 / 0518: 20$ & Casino fills in Master & 28 \\
\hline $2 / 25 / 0518: 20$ & $3 / 1 / 058: 20$ & Good Data & 28 \\
\hline $3 / 1 / 058: 20$ & $3 / 29 / 0518: 20$ & Casino fills in Master & 6 \\
\hline $3 / 29 / 0518: 20$ & $4 / 4 / 058: 20$ & Good Data & 264 \\
\hline & & & 65 \\
\hline & Totals: & Good Data & 68 \\
\hline & & Missing Data & \\
\hline & & Filled data & \\
\hline
\end{tabular}

\subsubsection{Wind Data Analysis}

Wind Data was received monthly and given summery analysis at that time. This preliminary analysis ensured that the data was being collected properly, and also gave an indication of the resource for the month. When a year of data was available, the following steps were used to process that data. Initially, a wind speed ratio was set up between the two meteorological towers for correlating data between the two. This correlation was used to fill in data from one met site to the other for periods of time when one had data and the other did not. There were 68 days where data was only available from one anemometer. For 65 days data was not collected by either anemometer. One option for dealing with the lack of data is to assume the data for the rest of the year is representative and use a typical sample of that data to represent the missing period. Unfortunately these 65 days were mostly in November, December, and January, when Viejas expects to receive the strong Santa Ana winds. An attempt was made to represent this by using data from October, December, January, and February around the periods of lost data to fill in the blanks. The disadvantage of the technique used is that data 
collected around the voids is double counted and, in the case of the period December 2 through 17, triple counted. If this data is not representative, it has a disproportionate skewing effect on the analysis. Results of the analysis using this technique show a significant increase in annual energy production compared to using only the data collected. These results have increased uncertainty caused by the missing data.

The annual data set once established was scaled for annual variations based on long term data. The long term data available from Campo, CA, and Palm Springs, CA, although having poor correlation with the anemometer at Viejas, is sufficient to give a sense of annual wind variations in the region. Both of these sites showed that 2004 was a slow wind speed year by about ten percent compared to an 8 year average. Thus the wind speeds measured at Viejas were scaled upward by ten percent to represent a 'typical' year. These typical year wind speed values were then used in Black \& Veatch's wind turbine model.

The turbine model first scales wind speeds to a selected turbines hub height using the wind shear exponent measured at the site or assumed by terrain. At Viejas a wind shear exponent of 0.1 was measured from the difference between wind speeds at ten meters and wind speeds at twenty meters. The turbine model then separates the scaled wind speeds into $1 \mathrm{~m} / \mathrm{s}$ bins. For example, wind speeds from $4.5 \mathrm{~m} / \mathrm{s}$ to $5.5 \mathrm{~m} / \mathrm{s}$ are all placed into the $5 \mathrm{~m} / \mathrm{s}$ bin. These binned wind speeds are then combined with a wind turbine manufacturers published power curve to give annual power output. Two likely turbines were selected for this analysis both having a rating of $950 \mathrm{~kW}$, the Vestas NM54 and the Suzlon S64. The Suzlon turbine is designed for slow wind speeds, and outperformed the Vestas turbine on an energy capture basis. Energy capture is not the only factor in selecting a turbine. Cost and maintenance are also key factors. Losses were assumed to be five percent, to account for blade soiling, turbulence, electrical, and other losses.

Of the two anemometry sites, the Casino site was chosen to perform the detailed analysis of evaluating a single turbine project. Such a project would likely be net metered through one of the casino utility meters, and thus a location near the casino is appropriate. Furthermore, the Casino site has the more complete data set of the two. Data analyzed from the Master site yields very similar results to those shown for the Casino site.

A wind power and frequency of occurrence rose is shown in Figure 5-6. The graphic clearly shows that winds at this site are almost exclusively from the northeast or the southwest. This makes sense because the site is located in a valley of similar orientation, and because of the east-west coastal wind regime of the area. Good exposure to the wind in each of these directions is critical for maximum energy capture. 
Conversely obstacles outside of these directions can be quite prominent without having a significant impact on energy capture.

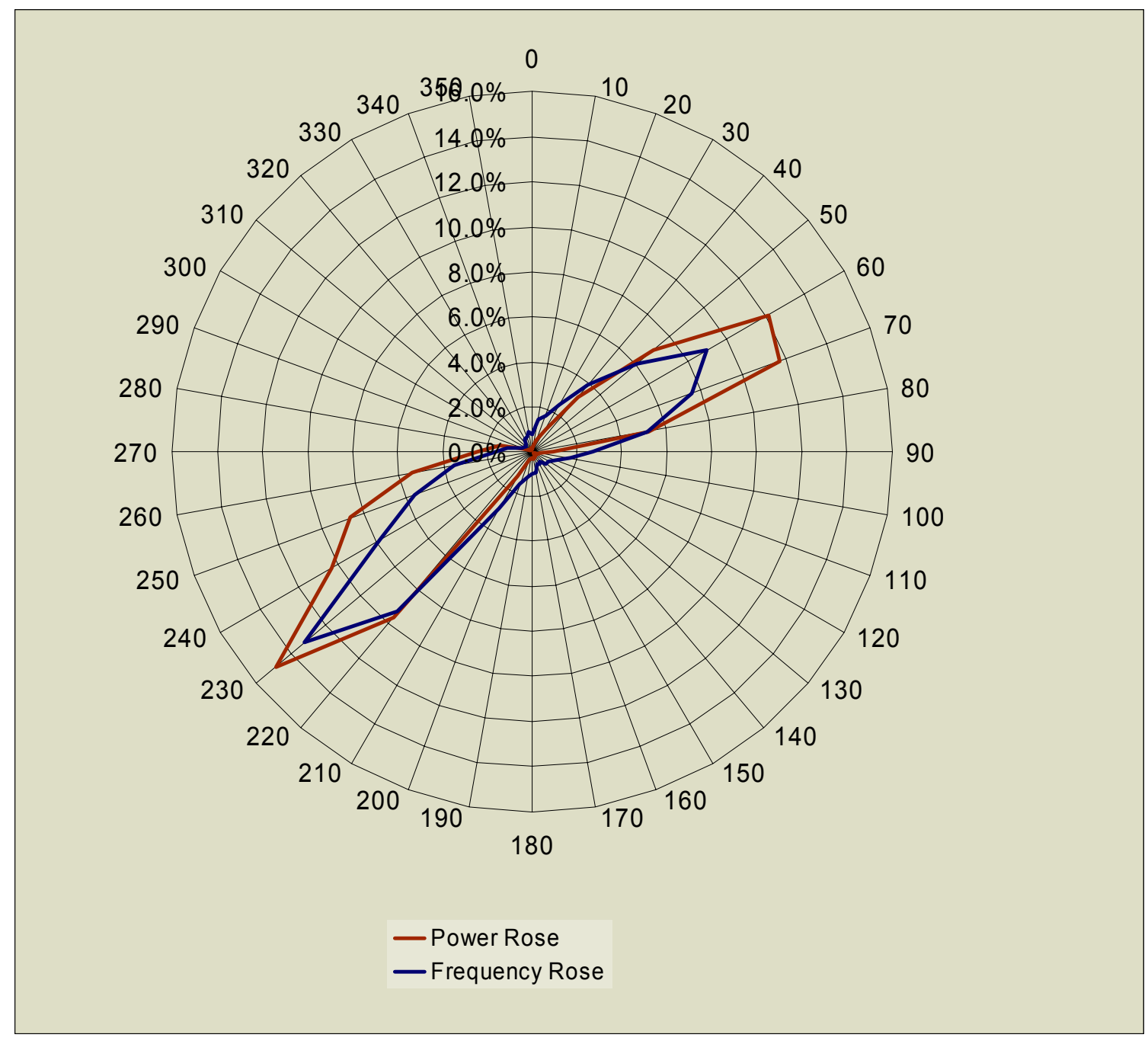

Figure 5-6. Wind Rose for Casino Site.

Figure 5-7 shows the annual average daily distribution of wind power production. The Viejas valley has a strong afternoon peak in power production. This peak corresponds well to the summer peak power pricing period between 11 am and $6 \mathrm{pm}$. As can be seen in the figure, almost 60 percent of wind power generation occurs over these seven hours. 


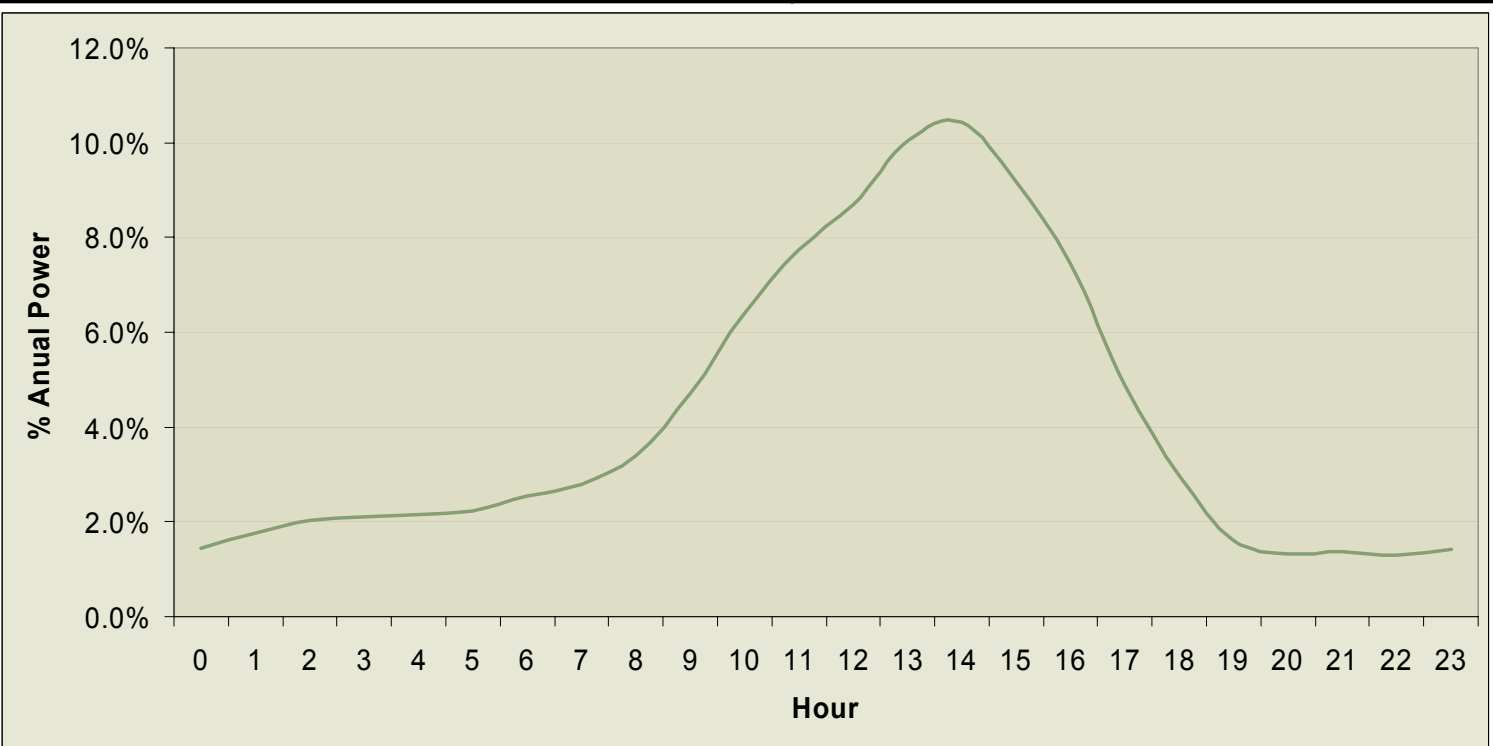

Figure 5-7. Power Production by Time of Day.

Figure 5-8 shows the theoretical power output by month for the measured year. It should be noted that almost none of November, and only half of December and January were actually recorded due to data logger failures. These data were estimated by repeating data from earlier or later periods and may not be representative. Due to the uncertainty of the winter months' data, poor correlation to known sites, and only one year of measurement, it is not clear what seasonal pattern to expect.

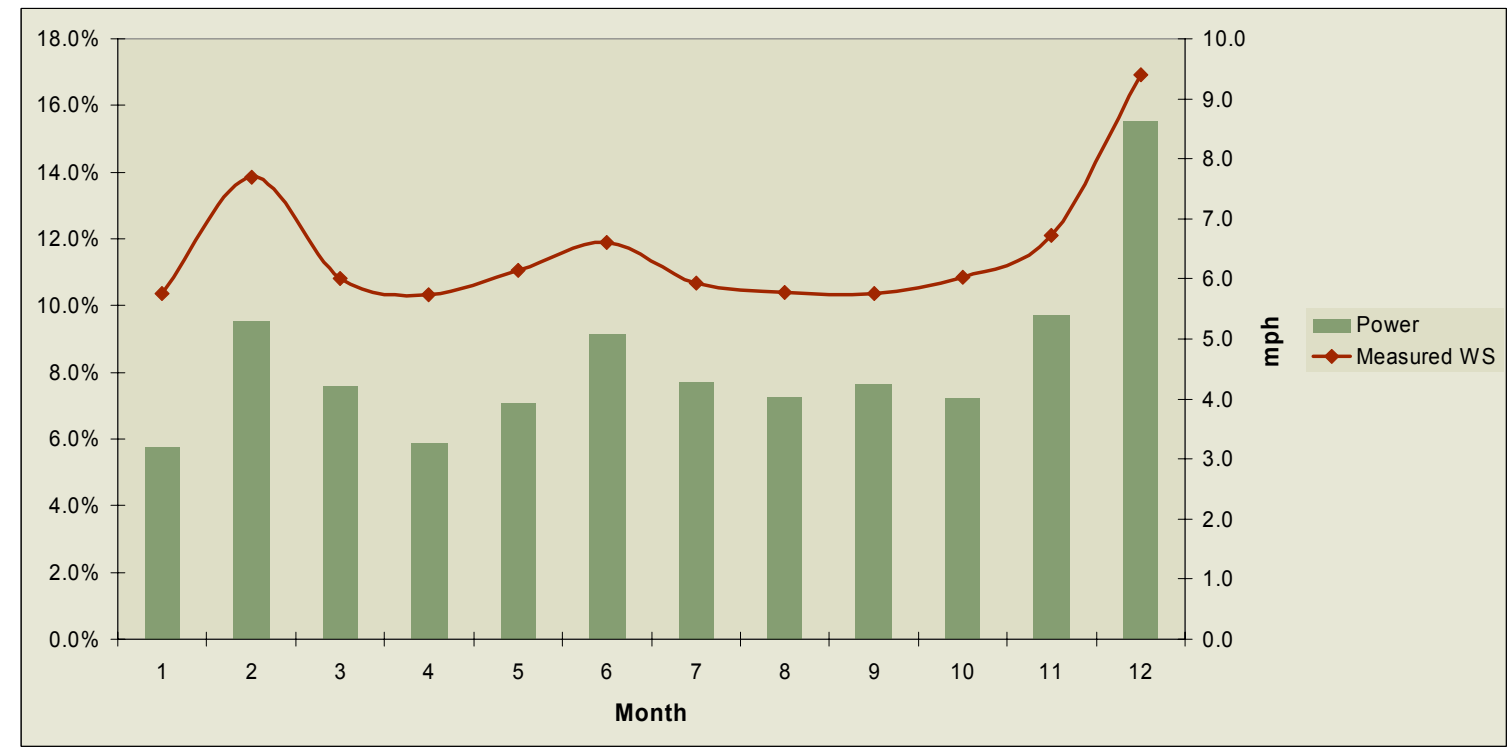

Figure 5-8. Monthly Power Output.

Figure 5-9 shows the power curve for a Suzlon S64 $950 \mathrm{KW}$ wind turbine plotted in red. The actual wind speed frequency distribution for the year measured is represented 
by green bars. It can be seen that much of the time wind is slower than the $3 \mathrm{~m} / \mathrm{s}$ cut in wind speed of the turbine. The blue line shows that most of the energy is produced at modest wind speeds between five to ten meters per second. This highlights the importance of selecting a turbine designed for low wind speed performance.

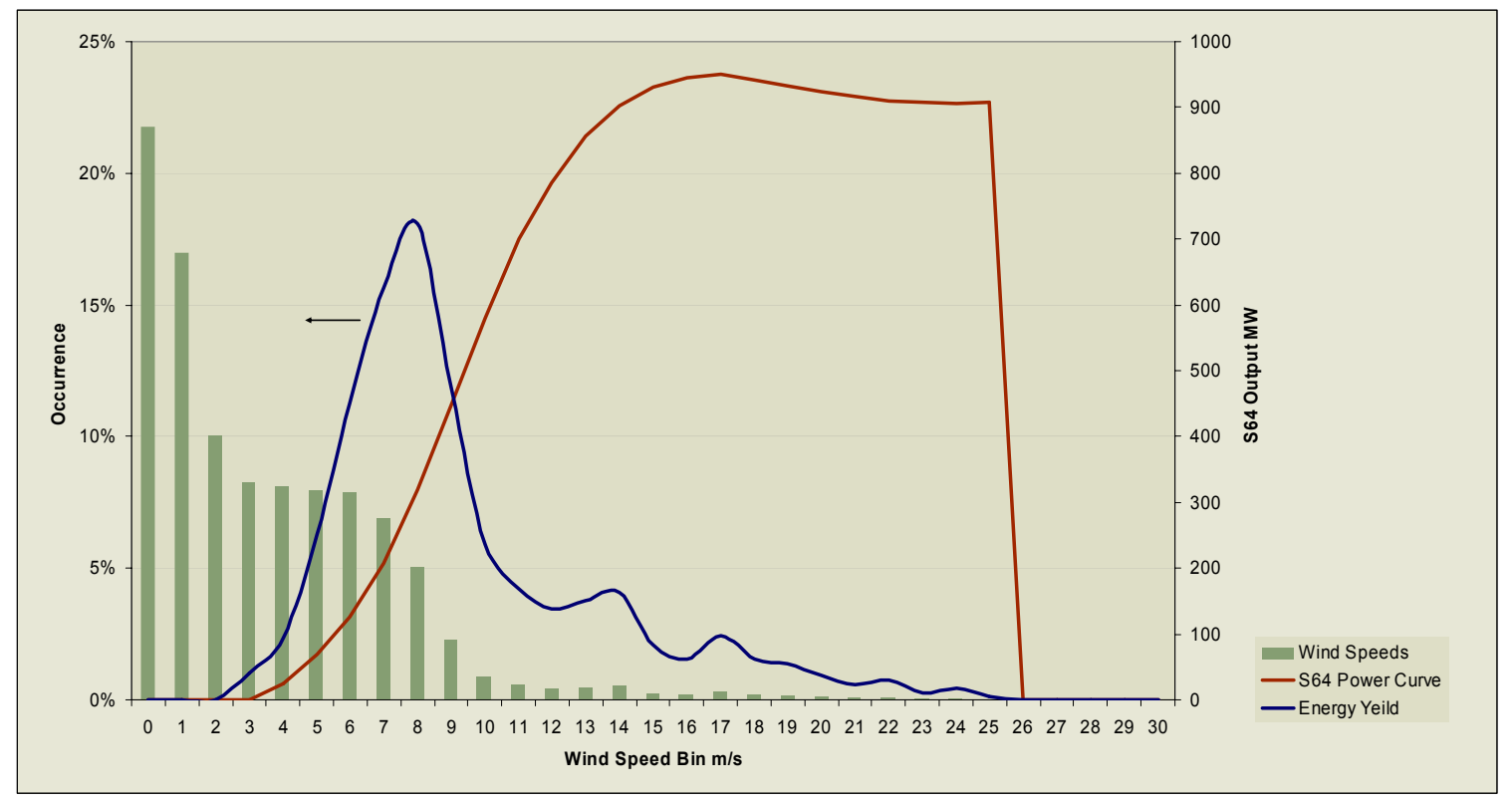

Figure 5-9. Casino Wind Speed Distribution.

Using the above described method, a capacity factor of 12.7 percent was predicted for the Casino site using a Suzlon S64 $950 \mathrm{~kW}$ turbine at 60 meter hub height. This gives an annual energy yield of 1,100 MWh. Using the Vestas NM54 $950 \mathrm{~kW}$ turbine at 60 meter hub height, a capacity factor of 9.5 percent was predicted with an annual energy yield of $840 \mathrm{MWh}$. It should be noted that due to the relatively low height above ground level of data collection, missing data, and poor correlation with historical wind data the above estimated capacity factors have a fairly high level of uncertainty. The main reason for the difference in capacity factors for the two turbines is the Suzlon turbine has a 64 meter diameter rotor and the Vestas rotor is 54 meters in diameter. Though the turbines have the same kilowatt rating, their output at low wind speeds is very different due to the amount of swept area of the blades. Energy yield is not the only factor in selecting a turbine. Capital cost, maintenance requirements, and other factors have a strong impact.

Time of Energy production was analyzed for the Suzlon turbine scenario to investigate the value of energy produced. Value was based on the time of use rates the Viejas Casino is currently on. Using rates most prevalent during the period studied, it is estimated a Suzlon S64 turbine would have generated \$83,000 in savings for the March 2004 to March 2005 period. If the year had been one with typical winds \$103,000 would 
have been saved from the single turbine according to B\&V Analysis. The SDG\&E ALTOU electrical rate recently decreased by about $\$ 5 / \mathrm{MWh}$ from those used to obtain the above dollar figures.

It should be noted that the average annual energy yield estimates are based on data collected significantly below hub height, in a low wind speed year, with some large gaps in the data set. The assumptions used to fill in the gaps of the data, adjust to hub height, and to represent a typical year have a very strong effect on the estimate. While these assumptions were made using industry recognized techniques this does not eliminate the significant uncertainty of the results. Data is continuing to be collected and long term data may become available from the Manzanitas Band of Kumeyaay Indians. If the economics of proceeding with a single turbine project are marginal this additional data should be evaluated and an uncertainty analysis performed to aid in decision making.

Data was also input into wind industry software WASP TM and WindFarmer ${ }^{\text {TM }}$ to model wind speeds across the Viejas area.

Figure 5-11 below is a map of the Viejas and Capitan Grande reservation areas and relative wind power densities. Red and fuchsia areas indicate the highest wind power density, while light blue indicates the lowest. Because measured data is only from the valley floor the usefulness of the model is restricted to only give a rough estimate of wind conditions at higher elevations in the surrounding area. Though not suitable for planning a wind farm, this information is valuable for identifying areas to place an anemometer to gather data, and gives a general idea of the resource distribution.

Figure 5-12 shows to greater resolution the wind power densities on the Viejas valley floor. Heavy black lines indicate approximate reservation borders. The map shows that the Casino is in a higher wind area of the Viejas Reservation and that wind speeds tend to increase to the south. Note the entire region of Figure 5-12 is in the lower range of wind resource from the larger area map of Figure 5-11. The gradients on both of these wind maps are on a relative scale. This shows the variation of wind resource across the terrain and is not intended to indicate a specific wind class. 
Viejas Tribal Government

Renewable Energy Development on Tribal

Lands of Viejas Study

5.0 Renewable Energy Alternatives

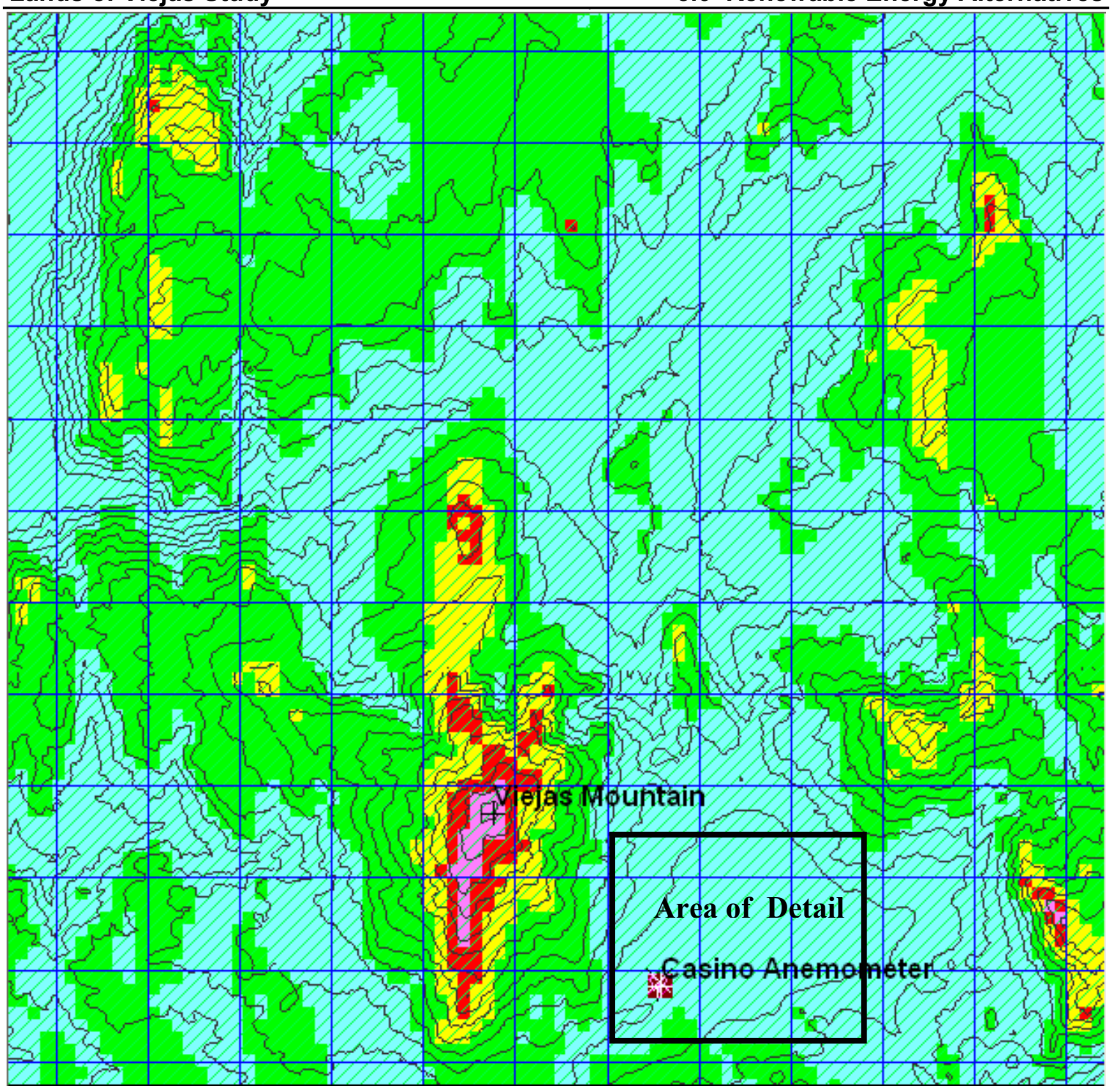

Figure 5-10. Wind Resource Gradient, Viejas and Capitan Grande 


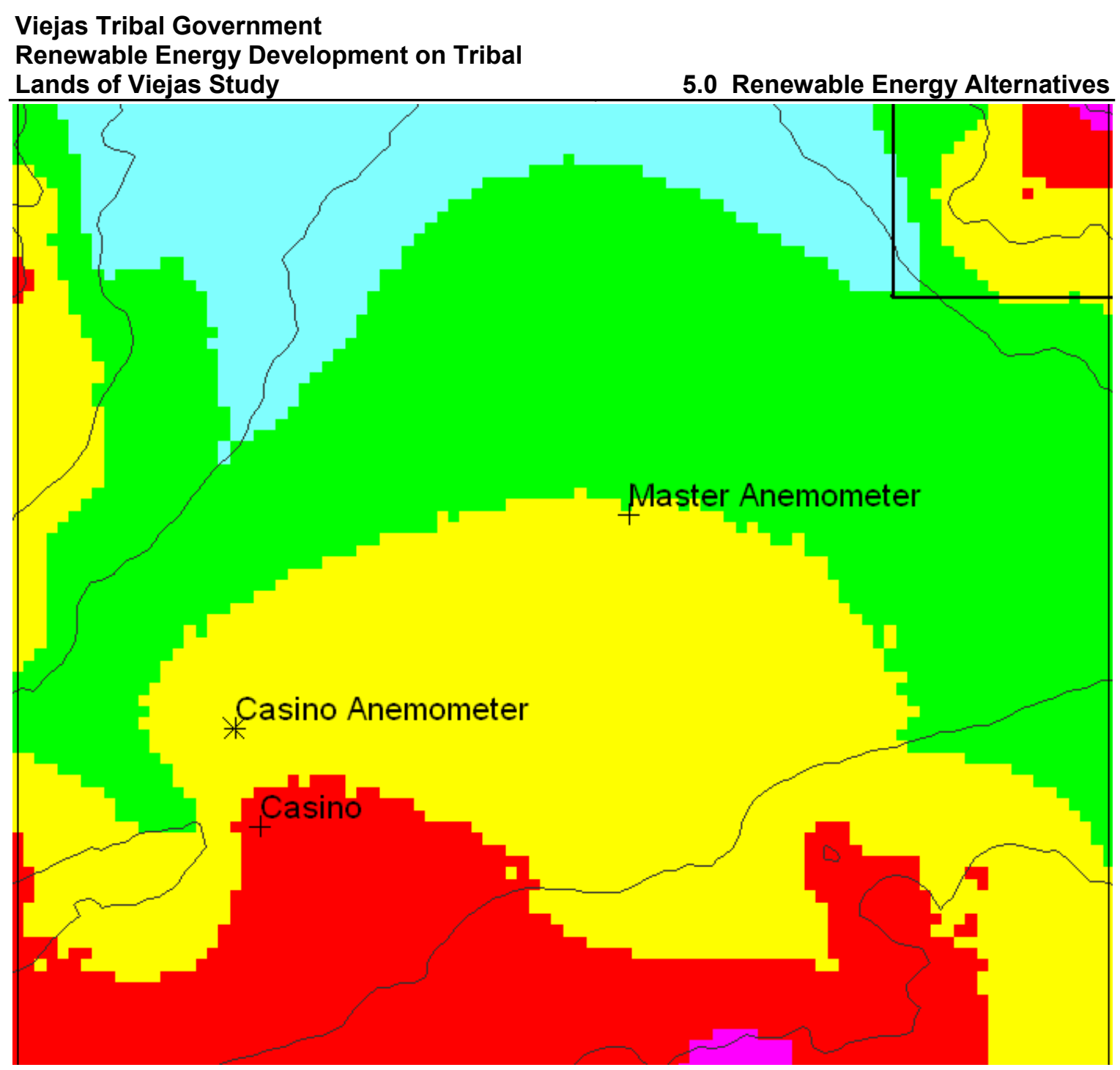

Figure 5-11. Wind Resource Gradient, Viejas Valley Floor.

\subsection{Solar thermal}

\subsubsection{Technical Description}

Solar thermal technologies convert the sun's energy to productive use by capturing heat. Early developments in solar thermal technology focused on heating water for domestic use. Advances have expanded the applications of solar thermal to high magnitude energy collection and power conversion on a utility scale. Numerous solar thermal technologies have also been developed over the past three decades as potential sources of renewable power generation. The leading technologies currently include parabolic trough, parabolic dish, power tower (central receiver), and solar chimney. Solar hot water heating is a developed and economical technology and could be considered as a part of a load reduction program. 


\section{Viejas Tribal Government \\ Renewable Energy Development on Tribal}

Lands of Viejas Study

5.0 Renewable Energy Alternatives

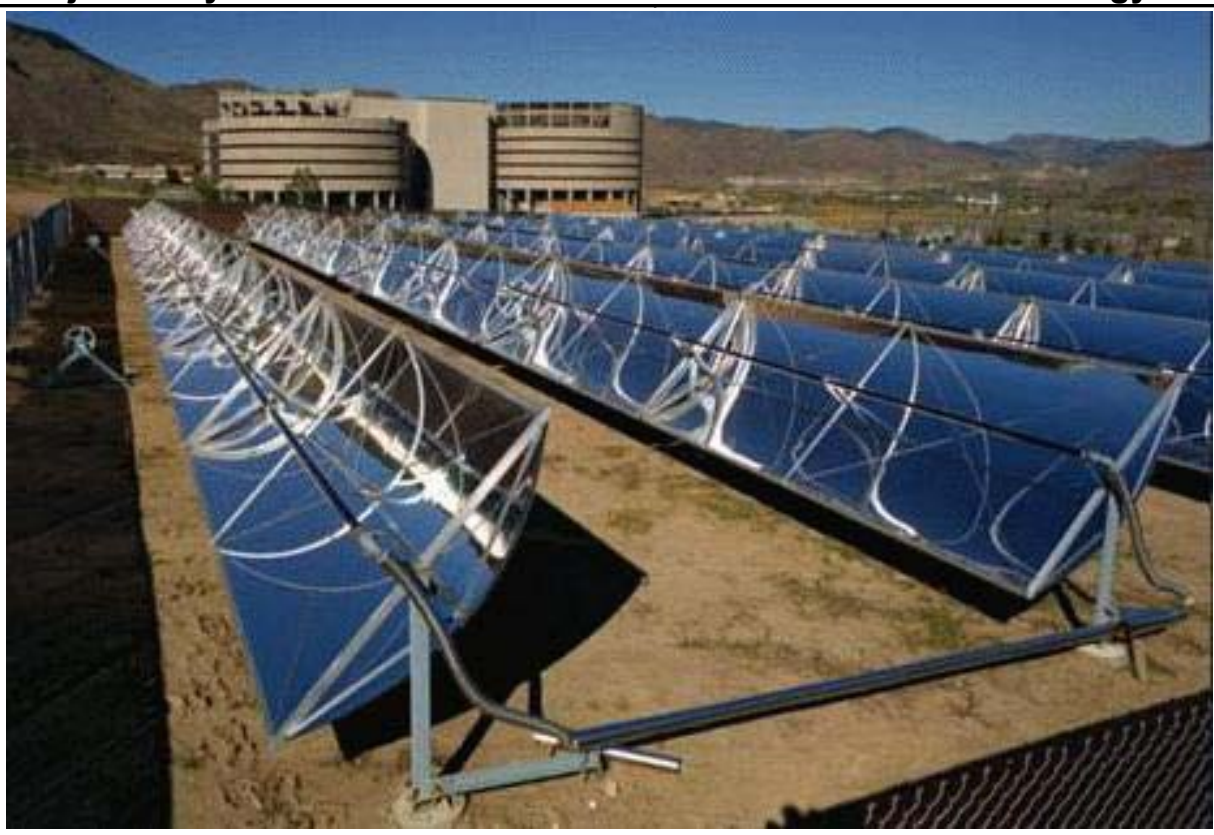

Figure 5-12. Parabolic Trough Field (Source: Union of Concerned Scientists)

With adequate resources, solar thermal technologies are appropriate for a wide range of intermediate and peak load applications including central station power plants and modular power stations in both remote and grid-connected areas. There is currently $350 \mathrm{MW}$ of solar thermal parabolic trough plants installed in California.

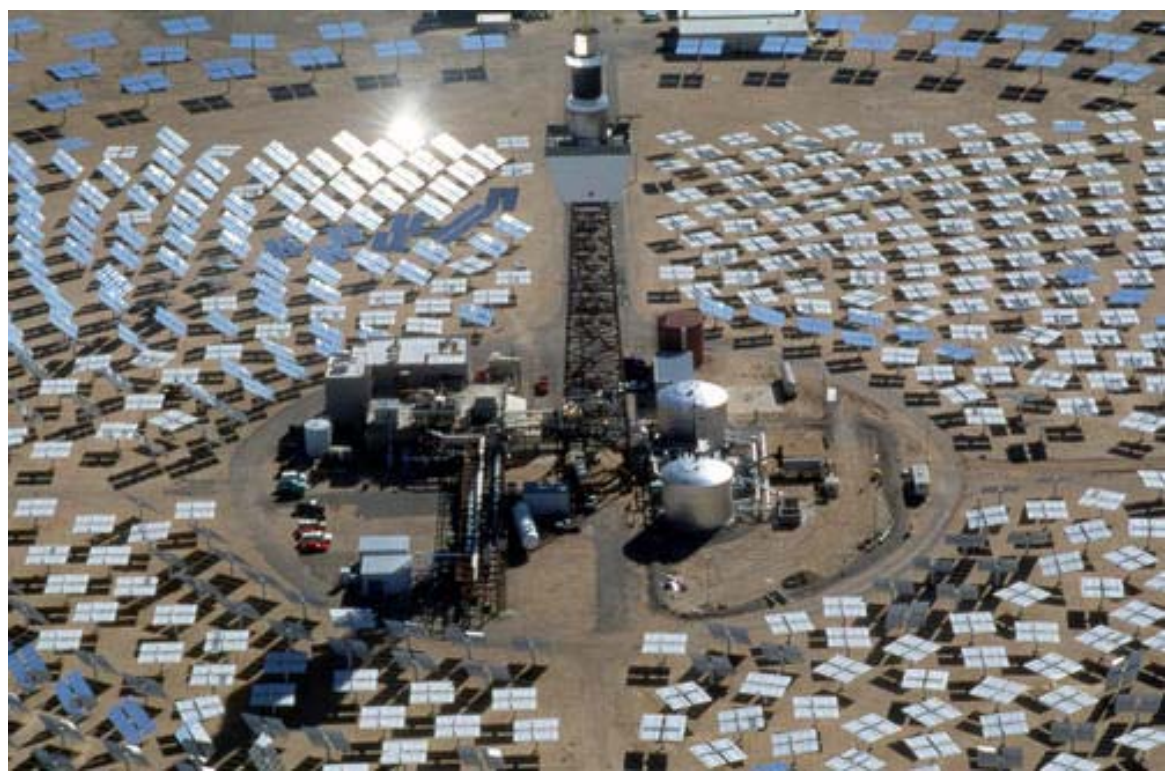

Figure 5-13. Solar Two Central Receiver Installation 
Solar trough and solar tower systems transfer the heat in solar radiation to a heat transfer fluid, heat transfer oil or molten salt, respectively. A heat exchanger converts the energy in the heat transfer fluid to steam, which is subsequently used to power a steam turbine. Solar thermal technologies may be combined with co-utilization of fossil fuels or energy storage to provide a dependable dispatchable resource. A thermal storage tank can be used to store hot heat transfer fluid, providing thermal energy storage. By using thermal storage or by combining the solar system with a fossil-fired system (a hybrid solar/fossil system), a solar thermal plant can provide dispatchable electric power. Parabolic dish systems use hydrogen as a working fluid to capture the solar heat and power a Stirling cycle engine. Energy storage is not an option for any pre-commercial parabolic dish systems.

Solar chimneys do not generate power using a thermal heat cycle as the other three technologies do. A solar chimney plant is essentially a tall chimney located in the center of a large greenhouse. As the air in the greenhouse is heated by the sun, it rises and enters the chimney. The natural draft produces a wind current, which rotates a collection of wind turbines in the chimney. The first commercial solar chimney is currently under development in Australia.

\subsubsection{Applications}

The larger solar thermal technologies (parabolic trough, central receiver and solar chimney) are currently not economically competitive with other central station generation options (such as natural gas combined cycle). Parabolic dish engine systems are small and modular and can be placed at load sites, thereby directly offsetting retail electricity purchases. However, these systems are still under development and do not have a long track record in commercial applications. 


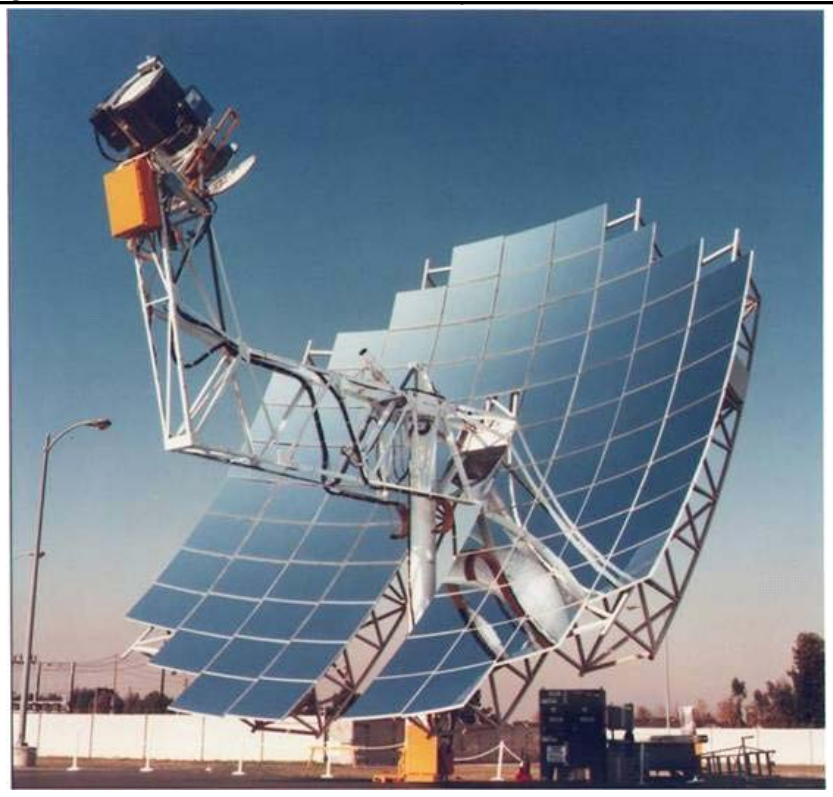

Figure 5-14. Parabolic Dish Receiver (Source: Stirling Energy Systems).

Parabolic trough represents the vast majority of installed solar thermal capacity. There are nine SEGS (Solar Electric Generating Station) parabolic trough plants in the Mojave Desert that have a combined capacity of $354 \mathrm{MW}$. These plants were installed from 1985 to 1990 and have been in continual operation since that time. Other parabolic trough plants are being developed, including a $50 \mathrm{MW}$ plant in Nevada. Small parabolic dish engine systems have been developed and are now being actively marketed. These dishes are typically about $25 \mathrm{~kW}$ in size. The US government has funded two utilityscale central receiver power plants: Solar One and its successor/replacement, Solar Two. Solar Two was a $10 \mathrm{MW}$ installation near Barstow, California, which is no longer operating due to reduced federal support and high operating costs. A project is proposed in Australia to build a $200 \mathrm{MW}$ solar chimney. The estimated cost is $\$ 700$ million and would include a chimney one kilometer $(0.62 \mathrm{mi})$ tall with an accompanying greenhouse $5 \mathrm{~km}(3.1 \mathrm{mi})$ in diameter.

\subsubsection{Resource Availability}

Concentrating solar thermal systems (troughs, dishes, and central receivers) use direct normal insolation. Lower latitudes with minimum cloud cover offer the greatest solar concentrator potential. An advantage of solar thermal systems, and generally all solar technologies, is that peak output typically occurs on summer days when electrical demand is high. Solar thermal systems with storage provide a dispatchable resource which can improve matching plant output to load requirements. 
Viejas Tribal Government

Renewable Energy Development on Tribal

Lands of Viejas Study

5.0 Renewable Energy Alternatives

\subsubsection{Cost and Performance Characteristics}

Representative characteristics for the four solar thermal power plant technologies are presented in Table 5-4.

Table 5-4. Solar Thermal Technology Characteristics.

\begin{tabular}{|c|c|c|c|c|}
\hline & $\begin{array}{c}\text { Parabolic } \\
\text { Trough }\end{array}$ & $\begin{array}{c}\text { Parabolic } \\
\text { Dish }\end{array}$ & $\begin{array}{l}\text { Central } \\
\text { Receiver }\end{array}$ & $\begin{array}{c}\text { Solar } \\
\text { Chimney }\end{array}$ \\
\hline \multicolumn{5}{|l|}{ Performance } \\
\hline Typical Duty Cycle & $\begin{array}{l}\text { Peaking - } \\
\text { Intermediate }\end{array}$ & $\begin{array}{l}\text { As available, } \\
\text { Peaking }\end{array}$ & $\begin{array}{c}\text { Peaking - } \\
\text { Intermediate }\end{array}$ & $\begin{array}{c}\text { Intermediate } \\
\text { Baseload }\end{array}$ \\
\hline Net Plant Capacity, MW & 100 & 0.025 & 50 & 200 \\
\hline Integrated Storage? & 12 hours & No & 16 Hours & Yes \\
\hline Capacity Factor, percent & $40-55$ & $20-25$ & $60-80$ & $60-80$ \\
\hline \multicolumn{5}{|l|}{ Economics } \\
\hline Capital Cost, $\$ / \mathrm{kW}$ & $5,200-6,500$ & $3,900-5,200$ & $6,500-9,100$ & $4,600-5,900$ \\
\hline Variable O\&M, \$/MWh & 33-39 & $13-26$ & $13-26$ & $13-26$ \\
\hline Levelized Cost, \$/MWh & $133-164$ & $150-350$ & $115-133$ & $87-99$ \\
\hline \multicolumn{5}{|l|}{ Technology Status } \\
\hline Commercial Status & $\begin{array}{c}\text { Early } \\
\text { Commercial }\end{array}$ & Demonstration & $\mathrm{R} \& \mathrm{D}$ & $\mathrm{R} \& \mathrm{D}$ \\
\hline Installed US Capacity, MW & $\sim 350$ & $<1$ & $10^{*}$ & $<1$ \\
\hline Viejas Potential & Fair & Moderate & Poor & Poor \\
\hline
\end{tabular}

\subsubsection{Suitability to Viejas}

A large experimental central receiver or solar chimney plant would not be suited well to providing power to Viejas because of the high risks associated with these technologies. It is conceivable that at a future date a parabolic trough plant could be constructed to produce power for both internal use and power sales. This could be attractive due to the energy storage capability of a solar trough system. The economical size of a solar trough power system is many times greater than the base load at Viejas so a trough system should only be considered if exporting power is a goal.

The most likely solar thermal technology for power production in the near term would be a parabolic dish system. This system can be installed incrementally $25 \mathrm{~kW}$ at a time reducing the risk associated with this technology. The incremental nature of this technology, like photovoltaic panels, allows for systems to be sized in order to match loads in a net metering scenario. At the time of this report parabolic dish systems are not commercially available. There has been a recent rush of activity with this technology 
though, and there is a reasonable likelihood that within the next few years there will be a commercial product available.

Solar hot water systems are common throughout California and can be implemented on a residential as well as a commercial scale. In a solar water heating system an array of solar collectors transfer the sun's heat to the hot water system. Heat can be transferred directly to the water stream or through a heat transfer fluid such as antifreeze or heat transfer oil. A solar hot water panel utilizes 80 percent of the energy of incident sunlight to heat water compared to solar electric panels which only convert 12 percent of incident energy into electricity. Solar hot water is not specifically within the scope of this study; this technology is mentioned here because it can be the most economical solar technology. Specific performance characteristics were not investigated but as a rule of thumb, solar hot water systems tend to pay for themselves within a reasonably short period (five to ten years). Considering Viejas' good solar resource and high cost of energy, this option should be further explored as part of an integrated energy efficiency and renewable generation effort.

\subsection{Photovoltaic}

Photovoltaics (PV) have achieved considerable consumer acceptance over the last few years. PV module production tripled between 1999 and 2002, reaching a worldwide output of $562 \mathrm{MW}$ in 2002 (the last year for which B\&V has reliable data). Worldwide grid-connected residential and commercial installations grew from $120 \mathrm{MW} / \mathrm{yr}$ in 2000 to nearly $270 \mathrm{MW} / \mathrm{yr}$ in 2002. The majority of these installations were in Japan and Germany, where strong subsidy programs have made the economics of PV very attractive. Large scale $(>100 \mathrm{~kW}) \mathrm{PV}$ installations have been added at a rate of about 5 MW per year over the last two years. ${ }^{2}$

\footnotetext{
${ }^{2}$ Paul Maycock, "PV market update", Renewable Energy World, July-August 2003.
} 


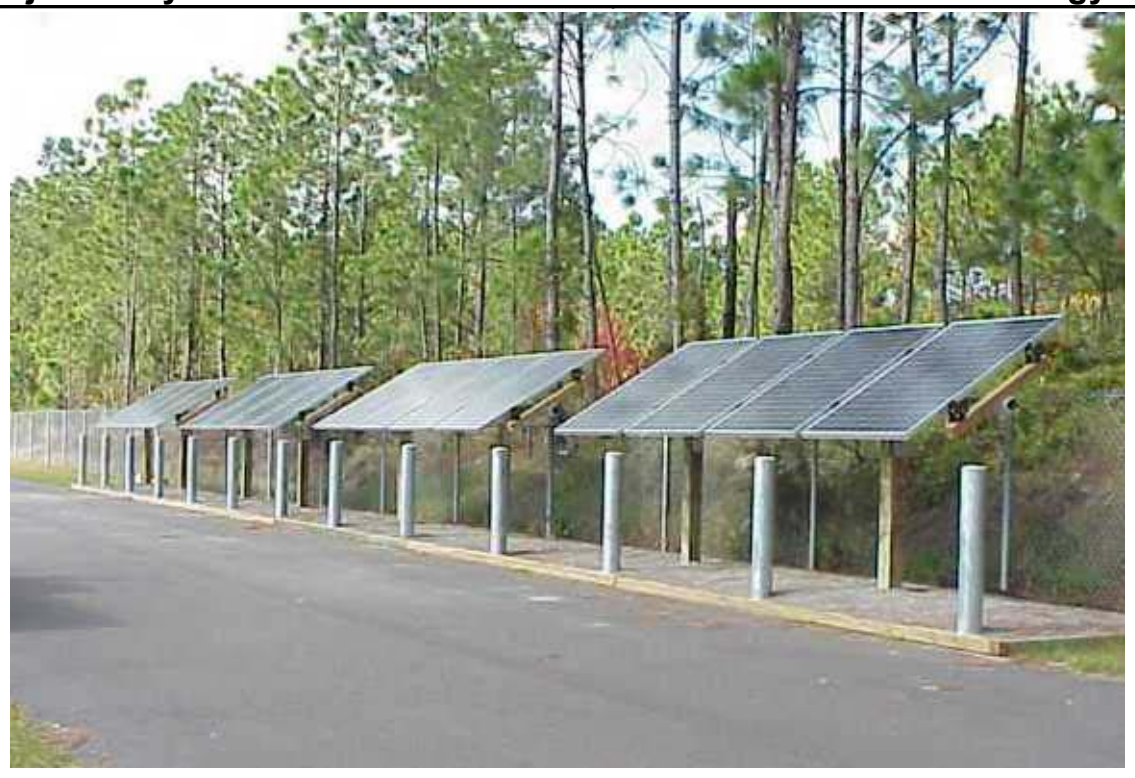

Figure 5-15. Photovoltaic Solar Panel Installation.

The amount of power produced by a PV cell depends on the materials of construction and the intensity of the solar radiation incident on the cell. Single crystal silicon cells are most widely used today. Single crystalline cells are manufactured by growing single crystal ingots, which are sliced into thin cell-size material. The cost of the crystalline material is a significant part of the cell production cost. Other methods of crystalline cell production (casting of polycrystalline material, pulling of cell-thickness ribbons) can cut material costs at some penalty to cell efficiency.

Another approach to reducing cell material cost is the development of thin film PV cells. Commercial thin films are principally made from amorphous silicon. Amorphous silicon cells suffer significant degradation and are not being seriously developed for large power applications. Copper indium diselenide and cadmium telluride thin films show promise as low-cost solar cells and are currently being researched. Thin film solar cells require very little material and can be manufactured on a large scale. Furthermore, the fabricated cells can be flexible and incorporated into building components. However, to date, thin film technology has not proven to compete on a cost effectiveness basis with crystalline silicon.

Gallium arsenide cells are among the most efficient solar cells and have other technical advantages, but they are also more costly. Gallium arsenide cells are typically used where high efficiency is regardless of cost, such as space applications. 


\subsubsection{Applications}

The modularity, simple operation, and low maintenance requirements of solar PV make it well suited for serving distributed, remote, and off-grid applications. Most PV applications are smaller than $1 \mathrm{~kW}$, although, larger utility-scale installations are becoming more prevalent. Current grid-connected PV systems are generally below 100 $\mathrm{kW}$. A 3.4 MW project is currently under construction in Arizona. This is one of the largest PV installations in the world. Most grid-connected PV applications require large subsidies (50 percent or more) and/or a high cost of power to overcome high initial costs.

\subsubsection{Resource Availability}

Solar radiation reaching the earth's surface, often called insolation, has two components: direct normal insolation (DNI) and diffuse insolation. DNI, which comprises about 80 percent of the total insolation, is that part of the radiation which comes directly from the sun. Diffuse insolation is solar radiation that has been scattered by the atmosphere or is reflected off the ground or other surfaces. All of the radiation on a cloudy day is diffuse. The vector sum of DNI and diffuse radiation is termed global insolation. Systems which concentrate solar energy use only DNI, while nonconcentrating systems use global radiation. Most PV systems installed today are flat plate systems that use global insolation. Concentrating PV systems, which use DNI, are being developed, but are not considered commercial at this time.

Generally, stationary (non-tracking) PV arrays will receive the highest average annual insolation if they are mounted at an angle equal to the latitude at which they are located. To optimize performance for winter, the array may be tilted at an angle equal to the latitude plus 15 degrees. Conversely, for maximum output during summer months the array should be tilted at an angle equal to the latitude minus 15 degrees. Single and double axis tracking systems increase the system output, but at a higher capital cost and increased O\&M requirements.

Solar potential analysis on the Viejas Reservation was conducted using PV Design Pro software developed by Maui Solar Energy Software Corporation. Typical solar year data was taken from Bakersfield, California which has a similar inland foothills climate to Viejas. The difference of about two degrees latitude between the sites was compensated for by adjusting tilt angle of the solar panels appropriately. Although data from San Diego was also available which is from a closer location with similar latitude; it is the opinion of Black \& Veatch that the coastal influence (e.g. morning fog) at the San Diego site did not well represent solar conditions at Viejas. The Bakersfield data set of 10 minute average solar insolation ${ }^{3}$ was then used in the computer model along with

\footnotetext{
${ }^{3}$ Insolation: The rate of delivery of solar radiation per unit of horizontal surface.
} 
Viejas Tribal Government

Renewable Energy Development on Tribal

Lands of Viejas Study

5.0 Renewable Energy Alternatives

power curves from actual solar panels, inverters and a hypothetical wiring arrangement to yield total energy output.

Likely locations for solar installations were discussed with Viejas facilities staff to determine the suitability of various sites. Rooftop, parking lot canopy, and ground based installations were considered in three main areas: the outlet mall, the casino, and residential areas

\subsubsection{Cost and Performance Characteristics}

Numerous variations in PV cells are available, such as single crystalline silicon, polycrystalline, and thin film panels. Several support structures are available, such as fixed-tilt, one-axis tracking, and two-axis tracking. For evaluation purposes, five single crystalline PV systems are characterized in Table 5-5: two $2.5 \mathrm{~kW}$ residential systems and three $100 \mathrm{~kW}$ commercial systems

Table 5-5. Solar PV Technology Characteristics.

\begin{tabular}{|c|c|c|c|c|c|}
\hline & $\begin{array}{c}\text { Fixed } \\
\text { Angle } \\
\text { Residential }\end{array}$ & $\begin{array}{l}\text { Two Axis } \\
\text { Tracking } \\
\text { Residential }\end{array}$ & $\begin{array}{c}\text { Commercial } \\
\text { Parking } \\
\text { Structure }\end{array}$ & $\begin{array}{l}\text { Commercial } \\
\text { Fixed Angle }\end{array}$ & $\begin{array}{c}\text { Commercial } \\
\text { One Axis } \\
\text { Tracking }\end{array}$ \\
\hline \multicolumn{6}{|l|}{ Performance } \\
\hline Typical Duty Cycle & $\begin{array}{c}\text { As } \\
\text { Available }\end{array}$ & $\begin{array}{c}\text { As } \\
\text { Available }\end{array}$ & $\begin{array}{c}\text { As } \\
\text { Available }\end{array}$ & $\begin{array}{c}\text { As } \\
\text { Available }\end{array}$ & $\begin{array}{c}\text { As } \\
\text { Available }\end{array}$ \\
\hline Net Plant Capacity, kW & 2.5 & 2.5 & 100 & 100 & 100 \\
\hline Capacity Factor, percent & $23 \%$ & $31 \%$ & $19 \%$ & $21 \%$ & $26 \%$ \\
\hline \multicolumn{6}{|l|}{ Economics } \\
\hline Capital Cost, \$/kW & $6,800^{*}$ & $8,000 *$ & $5,000 * *$ & $4,700 * *$ & $5,400 * *$ \\
\hline Fixed O\&M, \$/kW-yr & 45 & 50 & 20 & 20 & 26 \\
\hline Variable O\&M, \$/MWh & 52 & 60 & 23 & 23 & 30 \\
\hline Levelized Cost, \$/MWh & 360 & 332 & 220 & 193 & 193 \\
\hline \multicolumn{6}{|l|}{ Technology Status } \\
\hline Commercial Status & \multicolumn{5}{|c|}{ Commercial } \\
\hline Installed US Capacity & \multicolumn{5}{|c|}{$212 \mathrm{MW}$} \\
\hline Viejas Potential & \multicolumn{5}{|c|}{ Very Good } \\
\hline
\end{tabular}

* Includes \$2,300/kW California Energy Commission Buy-Down

** Includes $\$ 3,000 / \mathrm{kW}$ California SELFGEN Incentive 


\subsubsection{Household PV Stationary and Tracking}

One way of installing PV Capacity is to install a PV system at a number of the residences on the reservation. The CEC offers an incentive, currently worth $\$ 2.80$ per installed watt, for this type of installation. An advantage of household PV is that the electricity is generated at the site of the load thus reducing transmission losses. Another advantage of a household level installation is that a battery back up system can be installed as well for an incremental cost which would increase electrical reliability at the residences and provide a degree of energy storage for the system as a whole. The inverters employed for a back up system can provide a degree of voltage regulation by storing or releasing power from the batteries as the local grid requires. Household solar electric systems would engage residential members of the tribe in renewable energy development in a tangible way.

Household PV systems can be mounted on roof tops, on special mounting structures, or on the ground. For this study, two scenarios were analyzed: a fixed slope roof mounted array and a pole mounted two axis tracking array. Both were sized for 2.5 kW AC output and employed a small battery back up system.

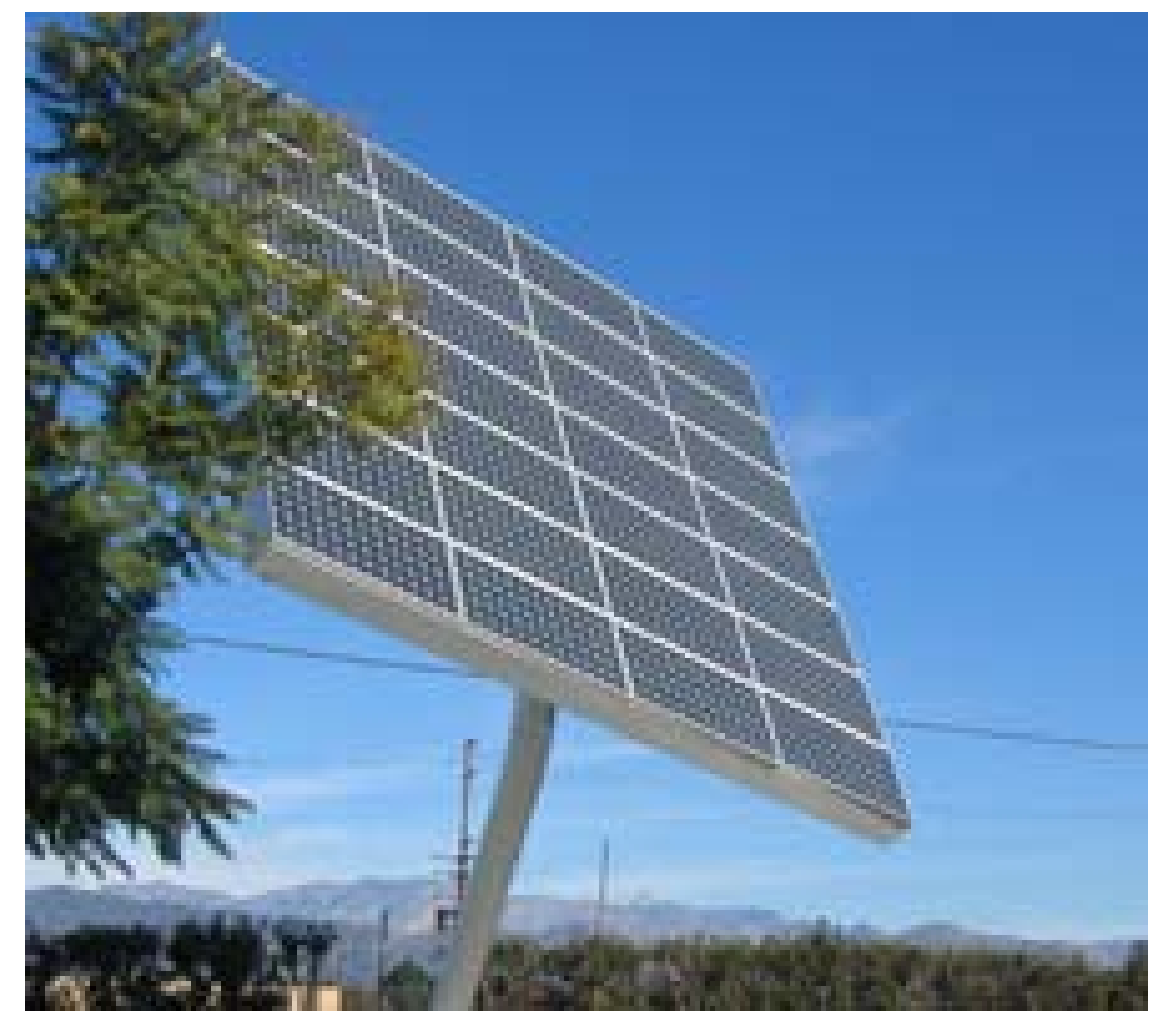

Figure 5-16. Pole Mounted Two Axis Tracking PV Array ${ }^{4}$

\footnotetext{
${ }^{4}$ Source: http://www.solartrax.com/ accessed April 3, 2005
} 
Viejas Tribal Government

Renewable Energy Development on Tribal

Lands of Viejas Study

5.0 Renewable Energy Alternatives

\subsubsection{Commercial PV Stationary and Tracking}

Several scenarios were analyzed for a large scale photovoltaic panel installation. The first is a standard fixed tilt rooftop mounted system. There is no space for solar panels on the casino roof, but the outlet mall has approximately 100,000 square feet of rooftop space available, enough for about $500 \mathrm{~kW}$ of PV.

Another option is ground based mounting which is more suited to large scale photovoltaic deployment. Fixed axis or single axis tracking is possible in this configuration. Land required for either scenario is approximately 1 acre for every 200 $\mathrm{kW}$ of PV.

A third option is a PV system mounted to provide shade for parking areas. Similar the rooftop system, this option would allow the same area of land to be used for multiple purposes. The panels can be either mounted flat or tilted toward the sun according to aesthetic and performance considerations. The outlet mall has enough parking area for approximately $2 \mathrm{MW}$ of PV. The casino parking area is big enough to theoretically accommodate up to $8 \mathrm{MW}$ assuming good solar exposure over the entire area.

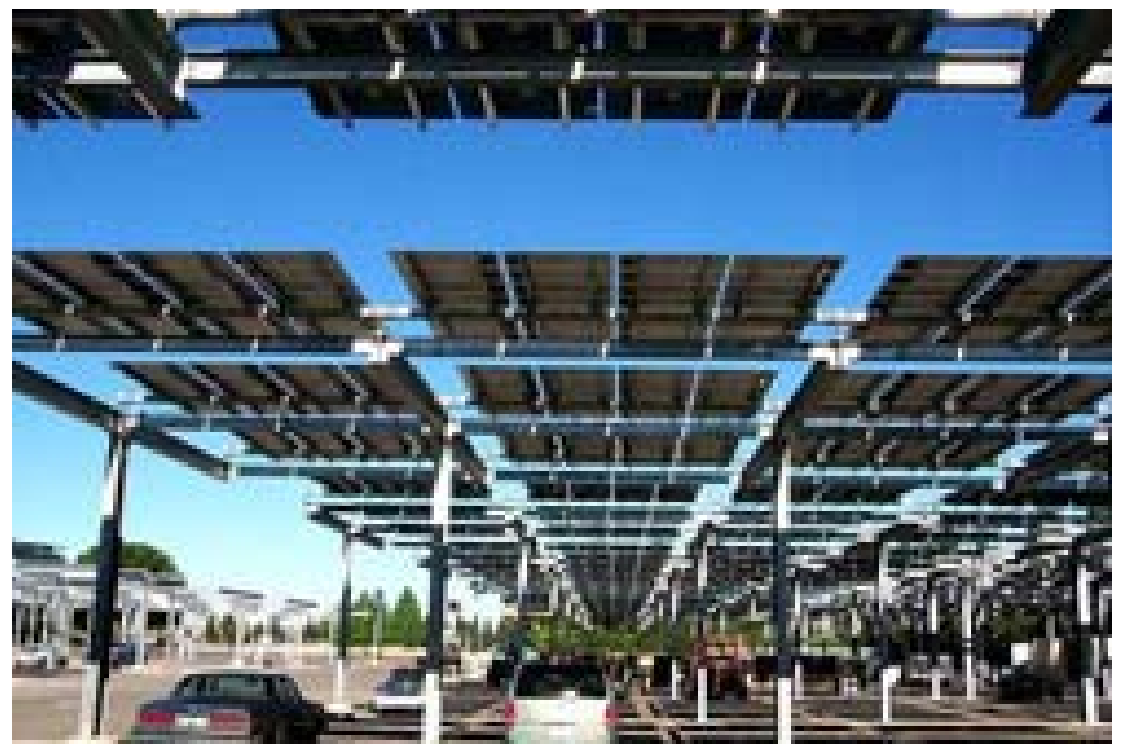

Figure 5-17. Parking Shade PV System. ${ }^{5}$

${ }^{5}$ Source: http://www.nrel.gov/buildings/pv/c_faq.html accessed May 17, 2005 


\subsection{Bio-Fuels}

\subsubsection{Biodiesel}

Biodiesel is a non-toxic, biodegradable, and renewable fuel that can be used in diesel engines with little or no modification. Biodiesel can be produced from oils such as animal fat, vegetable oil, and waste greases. Biodiesel is produced by breaking a triglyceride (fat) into three ester molecules (which are chain molecules chemically similar to diesel fuel) and a glycerin molecule. Sodium methoxide is added to the oil breaking the triglyceride and bonding methanol to the esters. The mixture to settles into two simpler constituents: glycerin and methyl-ester. The methyl-ester is collected, washed and filtered to yield biodiesel. The glycerin has several commercial uses, the most common of which is the manufacture of soap.

The facilities where biodiesel is produced are relatively simple and easily scaled to meet local needs. Two types of biodiesel production facilities are in operation today: batch plants and continuous flow plants. Batch plants tend to be much smaller than continuous flow plants and produce discrete quantities of biodiesel per batch. Continuous flow plants are usually much larger, run continuously, and are capable of implementing more efficient processes than those used in batch operations. Compared to ethanol, production of biodiesel is still in its infancy. There are very few large scale continuous flow biodiesel plants in operation in the United States at this time.

\subsubsection{Applications}

Biodiesel can directly displace diesel fuel in many applications. Biodiesel requires some special handling and storage procedures, and is limited to use during warm or temperate seasons/climates due to its viscous nature at low temperatures. No engine modifications are required for most static internal combustion (IC) engine applications. While there has been little study of biodiesel's performance in gas turbine engines, there has been extensive research and testing of the fuel's performance in traditional fourstroke IC engines. As such, biodiesel is already used in a variety of operations throughout the United States.

Biodiesel's greatest market potential lies within the transportation sector. However, diesel is generally the fuel of choice for most IC engine power production applications. As such, there is substantial potential for biodiesel to replace diesel fuel in the energy sector. A variety of stationary engine products are available for a range of power generation market applications and duty cycles including standby and emergency power, peaking service, intermediate and base load power, and combined heat and power. 
Viejas Tribal Government

Renewable Energy Development on Tribal

Lands of Viejas Study

5.0 Renewable Energy Alternatives

Reciprocating engines are available for power generation applications in sizes ranging from a few kilowatts to over $5 \mathrm{MW}$.

Diesel engines have historically been the most popular type of reciprocating engine for both small and large power generation applications. However, in the United States and other industrialized nations, diesel engines are increasingly restricted to emergency standby or limited duty-cycle service because of air emission concerns. While biodiesel does improve the emissions of a diesel engine, the improvements are not as significant as the emissions reduction provided by natural gas powered engines.

\subsubsection{Resource Availability}

The most basic feedstock for biodiesel is vegetable oil. The oil can be derived from a variety of sources including: soybeans, cotton, palm, rapeseed, sunflower seeds, and restaurant waste greases. These feedstocks are generally categorized as virgin (fats and oils that have not been previously used) and recycled (fats, oils, and greases that have been previously used). While recycled feedstocks tend to have lower costs, they are limited by their availability and a variety of socioeconomic factors that may not be completely controllable.

In the United States, soybean and corn oil are the two leading vegetable feedstock for biodiesel production. These two feedstocks are readily available throughout most of the country and can be grown in the large quantities necessary to meet large scale biodiesel production demands. The supply of recycled fats and oils is largely determined by the demand from the animal feed industry. While biodiesel demand has been known to have moderate impacts on corn and soybean production, it is unlikely that increases in the demand for biofuels will significantly impact the supply of animal fats or recycled greases. ${ }^{6}$

\subsubsection{Cost and Performance Characteristics}

Currently the production cost of biodiesel can range from about $\$ 1.50$ to $\$ 4.00$ per gallon, depending on the feedstock and production method. Biodiesel can be more cost effective when produced from low-cost oils (restaurant waste, frying oils, and animal fats), compared to commodity crops. In January 2005, Imperial Western, a local producer of biodiesel from waste vegetable oil, provided a price of $\$ 2.50$ a gallon by tanker truck delivered to Viejas.

Integration of biodiesel into the transportation sector has been limited due to the fact that nearly every major diesel engine manufacturer has imposed blend limits on

\footnotetext{
${ }^{6}$ Agricultural Marketing Research Center, "Biodiesel as a Value-added Opportunity,” available at http://www.agmrc.org/energy/info/biodieselopportunity.pdf, accessed 3 August 2004.
} 
Viejas Tribal Government

Renewable Energy Development on Tribal

Lands of Viejas Study

5.0 Renewable Energy Alternatives

biodiesel for warranted operations. Typically, the fuel composition may be restricted to a maximum of 5 percent biodiesel (B5) or 20 percent biodiesel (B20). See attached Caterpillar bio-fuel spec sheet for an example of one manufacturer's fueling recommendations. Recently, some manufacturers have raised their limits to 100 percent biodiesel (B100). Some users have elected to run their engines on B100 and other high percentage blends, conceding the manufacturer's warranty coverage; however, this is a risk that few operators are willing to take.

Gasoline and diesel fuel, and their biofuel counterparts ethanol and biodiesel, are quality controlled based on ASTM specifications. The recent establishment of the ASTM biodiesel specification was a major advance for manufacturers who now have an industry-accepted standard for quality. This new standard will likely lend itself to an increase in large-scale biodiesel production, as well as a greater acceptance of the biofuel by diesel engine manufacturers.

While biodiesel can be used in any standard diesel engine with little to no modification to the engine, due to its different properties, such as a higher cetane number, lower volatility, and lower energy content, biodiesel may cause some changes in the engine performance and emissions. These different properties can affect the injection timing and the diesel combustion process causing lower power output. In contrast, biodiesel has a higher concentration of oxygen (by weight) which lends itself to more complete combustion, and biodiesel's higher cetane number provides smoother combustion and less engine noise.

\subsubsection{Waste Vegetable Oil}

Research on vegetable oil fuel has shifted to biodiesel in recent years so there is very little literature on the use of straight vegetable oil (SVO) from the past 20 years (although interest was active before that time). It seems that the major problems were associated with the high viscosity of the fuel resulting in a course spray and un-burnt oil which would polymerize on cylinder walls and clog injectors. There is little in the literature to counter the assertion by modern advocates that pre-heating vegetable oil lowers the viscosity sufficiently for complete combustion.

There are currently many individuals in the United States who run their cars on SVO, but it is not without risk. Much of this risk is associated with a do-it-yourself approach. One of the larger companies performing SVO engine conversions interviewed for this study is optimistic about converting a large generator. The largest engines they have converted to date are semi trucks. The vendor was willing to perform a conversion on a generator but not willing to warrant success. The vendor offered to monitor the 
Viejas Tribal Government

Renewable Energy Development on Tribal

Lands of Viejas Study

5.0 Renewable Energy Alternatives

generator closely to identify early signs of degradation. If using straight vegetable oil is considered desirable, Black \& Veatch recommends converting the most expendable of the several generators at Viejas as a trial and convert others if successful. The conversion to SVO would likely violate the engine warranty. However, if the conversion were performed on an older engine the warranty would likely no longer be in effect.

Wartsila does sell generators rated for use with SVO. These generators are originally designed to run on crude oil or one of the more viscous fuel oils $(4,5,6)$. Two generators have been installed in Italy specifically for use with SVO. Wartsila staff noted that the acidity of the oil was the largest concern; so if waste vegetable oil is used some pre-treatment beyond filtering may be necessary. See the attached Wartsila generator Biofuel spec. in Appendix A. Generators from other manufacturers designed for viscous oils may also be able to run on SVO.

Yellow Grease is a commodity product sold for animal feed, cosmetics, and other uses and is essentially minimally processed waste vegetable oil. In California it typically can be obtained for about $\$ 1$ a gallon, additional processing would be needed to produce fuel quality oil.

\subsubsection{Biogas}

Anaerobic digestion is the naturally occurring process in which bacteria decompose organic materials in the absence of oxygen. The byproduct gas has 50 to 80 percent methane content. The most common applications of anaerobic digestion use industrial wastewater, animal manure, or human sewage. According to the European Network of Energy Agencies' ATLAS Project, the world wide deployment of anaerobic digestion in 1995 was approximately 6,300 MW for agricultural and municipal wastes. This is estimated to increase to $20,130 \mathrm{MW}$ in 2010 with the majority of that growth in municipal wastewater digestion.

\subsubsection{Applications}

Anaerobic digestion is commonly used in municipal wastewater treatment as a first stage treatment process for sewage sludge. Digesters are designed to convert the organic material or sewage sludge into safe and stable biosolids and methane gas. The use of anaerobic digestion technologies in wastewater treatment applications is increasing because it results in a smaller quantity of biosolids residue compared to aerobic technologies.

In agricultural applications, anaerobic digesters can be installed anywhere there is a clean, continuous source of manure. It is highly desirable that the animal manure be concentrated, which is common at dairy and hog farms. (Poultry litter is dryer and more 
Viejas Tribal Government

Renewable Energy Development on Tribal

Lands of Viejas Study

5.0 Renewable Energy Alternatives

suitable for direct combustion.) Dairy farms use different types of digesters depending upon the type of manure handling system in place at the farm and the land area available for the digester. A 600 to 700 head dairy farm generally produces sufficient manure to generate about $85 \mathrm{~kW}$. Hog farms typically use simple lagoon digesters because of the wetter manure and generate approximately $50 \mathrm{~kW}$ for every 500 swine.

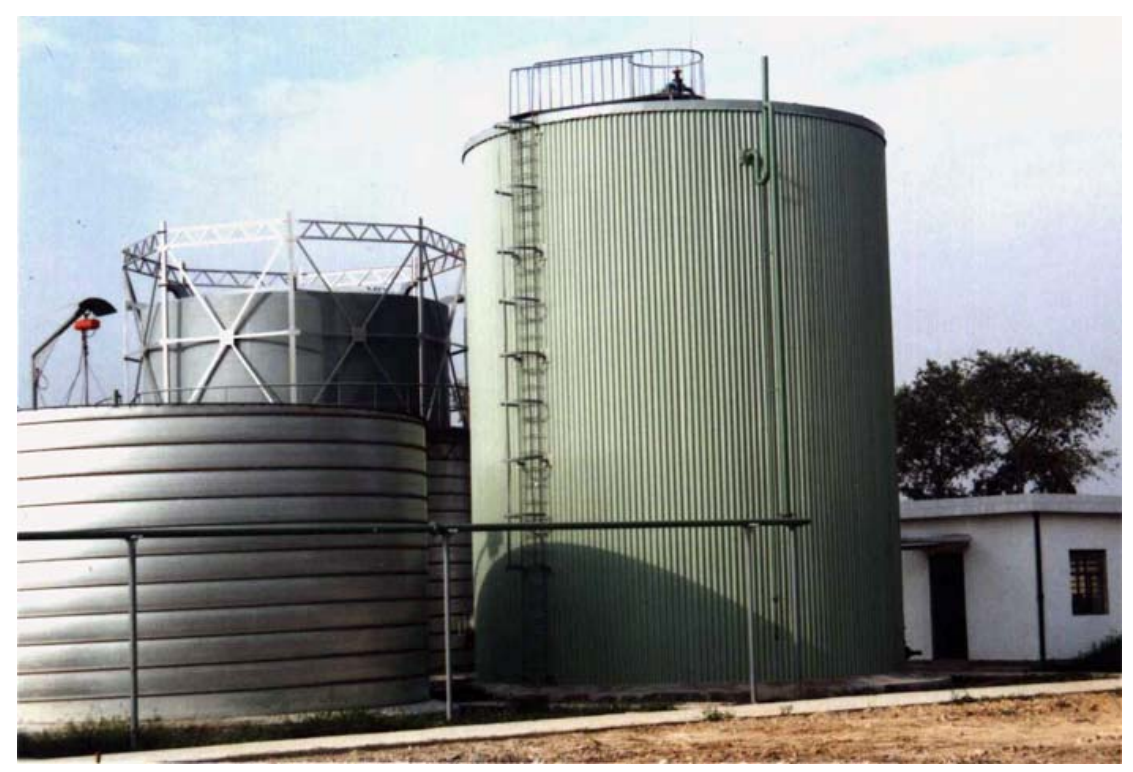

Figure 5-18. $500 \mathrm{~m}^{3}$ Digester Treating Manure from a 10,000 Pig Farm in China.

In addition to wastewater and agricultural residues, Los Angeles Department of Water and Power has announced a new agreement to purchase power from a $40 \mathrm{MW}$ anaerobic digestion facility that will process 3,000 tons per day of municipal green waste (such as landscape trimmings and food waste). The facility is scheduled to be on-line by 2009. This facility would be the largest of its kind in the world. Other high-solids digestion systems are installed world wide. These are primarily in Europe and Japan and use municipal solid waste and green waste as feedstocks.

Biogas produced by anaerobic digestion can be used for power generation, direct heat applications, and/or absorption chilling. Reciprocating engines are by far the most common power conversion device, although trials with micro turbines and fuel cells are underway. Agricultural digesters frequently satisfy the power demands for the farm on which they are installed, but do not provide significant exports to the grid. Municipal sewage sludge digesters generally produce enough gas to satisfy about half the wastewater treatment plant electrical load. Power production is typically a secondary

\footnotetext{
${ }^{7}$ Image source: Purdue University,

http://pasture.ecn.purdue.edu/ jiqin/PhotoDigester/PhotosDigesters.html.
} 
Viejas Tribal Government

Renewable Energy Development on Tribal

Lands of Viejas Study

5.0 Renewable Energy Alternatives

consideration in digestion projects. Increasingly stringent agricultural manure and sewage sludge management regulations are the primary drivers.

\subsubsection{Resource Availability}

The Viejas Wastewater treatment facility does not currently use an anaerobic digestion stage and the volume of waste flow is likely not sufficient to compel the addition of such a stage. It is possible that off site green waste or manure could be used in a biogas facility but due to Viejas' remote location transportation cost is likely to be an issue.

\subsubsection{Cost and Performance Characteristics}

Table 5-6 provides typical characteristics of farm-scale dairy manure anaerobic digestion systems utilizing reciprocating engine technology.

\section{Table 5-6. Anaerobic Digestion Technology Characteristics.}

\begin{tabular}{|l|c|}
\hline \hline Performance & \\
Typical Duty Cycle & Baseload \\
Net Plant Capacity, MW & 0.085 \\
Capacity Factor, percent & $70-90$ \\
Economics & \\
Capital Cost, \$/kW & $2,300-3,800$ \\
Variable O\&M, \$/MWh & 15 \\
Levelized Cost, \$/MWh & $80-120$ \\
Technology Status & \\
Commercial Status & Commercial \\
Installed Worldwide Capacity, MW & 6,300 \\
Viejas Potential & Fair \\
\hline \hline * Fuel cost of \$0/MBtu assumed.
\end{tabular}

\subsection{Cogeneration}

Cogeneration is the combined generation of electricity and heat. A given amount of fuel can provide twice the utility it would otherwise by both generating electricity and using the waste heat from that generation. Though not strictly 'renewable', cogeneration does offer an opportunity to reduce fossil fuel use through more effective use of fossil fuels. Furthermore most cogeneration technologies are suitable for operation with one or 
Viejas Tribal Government

Renewable Energy Development on Tribal

Lands of Viejas Study

5.0 Renewable Energy Alternatives

more renewable fuels, such as biodiesel, SVO, and biogas. Cogeneration requires heat and electric loads that are well matched. Usually one or the other is limiting. For Viejas one of two strategies can be employed. The first is installing cogeneration devices to meet the heat load of the reservation with electricity as a byproduct. In this scenario the value of each MWh generated is $\$ 30$ to $\$ 50$ higher due to the value of the heat provided (natural gas not burned). The second strategy would be to install thermal generation sized to meet electrical needs and finding ways of utilizing the waste heat. Various companies have integrated thermal generation sources and absorption chillers to provide electricity, cooling, and heating from a single package. In this way fuel use efficiency rises from approximately 33 percent for simply generating electricity to 70 or 80 percent by making use of the waste heat. Below are listed four thermal generation technologies and three potential uses for waste heat.

\subsubsection{Reciprocating Engines}

Reciprocating engines are well proven prime movers for electric generation, industrial processes, and many other applications. Reciprocating engines operate according to either an Otto or Diesel thermodynamic cycle, very much like a personal automobile. These cycles use similar mechanics to produce work, but differ in the way that they combust fuel.

\subsubsection{Operating Principles}

Reciprocating engines contain multiple pistons that are individually attached by connecting rods to a single crankshaft. The other ends of the pistons seal combustion chambers where fuel is burned. A mixture of fuel and air is injected into the combustion chamber and an explosion is caused. The explosion provides energy to force the pistons down and this linear motion is translated into angular rotation of the crankshaft by the connecting rods. The combustion chambers are vented and the piston pushes the exhaust gases out completing the full rotation of the crankshaft. The process is repeated and work is performed. 


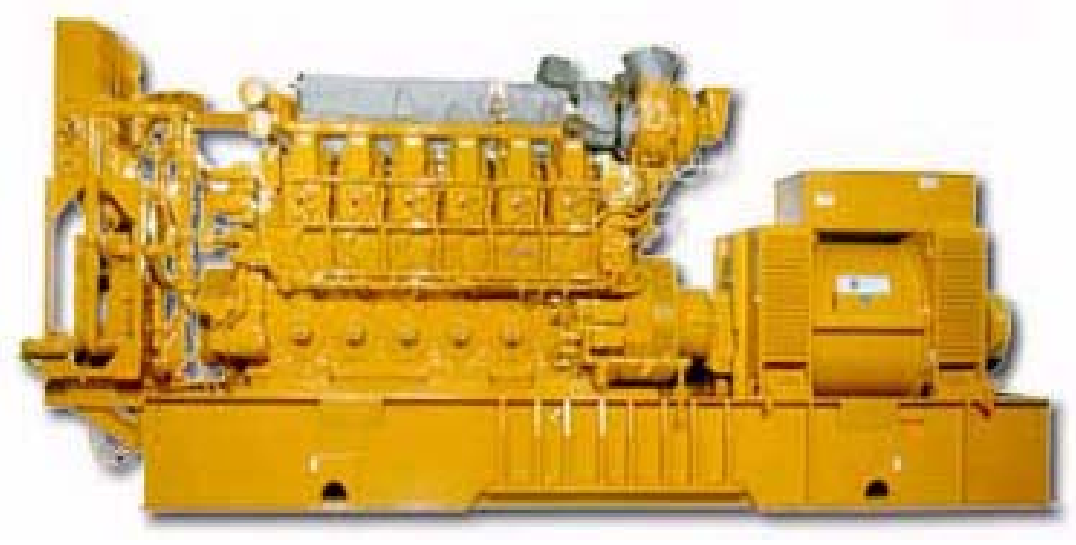

Figure 5-19. Engine Generator (Source: Caterpillar Corporation).

\subsubsection{Applications}

Reciprocating engine generator sets are commonly used for self-generation of power either for emergency backup or peak shaving. However, there is also a well established market for installation of generator sets as the primary power source for small power systems and isolated facilities that are located away from the transmission grid.

When used for power generation, medium speed engines (less than 1,000 rpm), are typically used since they are more efficient and have lower O\&M costs than smaller higher speed machines. Efficiency rates for reciprocating engines are relatively constant from 100 to 50 percent load, they have excellent load following characteristics, and they can maintain guaranteed emission rates down to approximately 25 percent load, thus providing superior part-load performance. Typical startup times for larger reciprocating engines are on the order of 15 minutes. However, some engines can be configured to start up and be completely operational within 10 seconds for use as emergency backup power.

\section{Fuel Flexibility}

Spark ignition and compression ignition engine generator sets can burn a wide variety of fuels. This list includes diesel, natural gas, biogas, landfill gas, ethanol, propane, naphtha, strait vegetable oil, and biodiesel. Because they have such flexibility, engine generators are well-suited for use as conventional or renewable power generation.

\section{Performance and Cost Characteristics}

Table 5-7 provides estimates of performance and costs for a reciprocating engine power station. 
Viejas Tribal Government

Renewable Energy Development on Tribal

Lands of Viejas Study

5.0 Renewable Energy Alternatives

Table 5-7. Reciprocating Engine Technology Characteristics

\begin{tabular}{|l|c|c|}
\hline \hline Engine Type & $\begin{array}{c}\text { Compression } \\
\text { (Biodiesel) }\end{array}$ & $\begin{array}{c}\text { Compression } \\
\text { (Vegetable Oil) }\end{array}$ \\
\hline Commercial Status & Commercial & Commercial \\
Performance & $1-10,000$ & $1-10,000$ \\
$\quad$ Net Plant Capacity, kW & 8,500 & 8,500 \\
Net Plant Heat Rate, Btu/kWh & $30-70$ & $30-70$ \\
Capacity Factor, percent & 600 & 800 \\
Economics & $15-25$ & $15-25$ \\
Capital Cost, \$/kW & 200 & 130 \\
Variable O\&M, \$/MWh & & \\
Levelized Cost, \$/MWh * & * Biodiesel \$15/MBtu, Vegetable Oil \$8/MBtu \\
\hline \multicolumn{2}{|c|}{} \\
\hline
\end{tabular}

\subsubsection{Combustion Turbine}

The first successful combustion turbine was completed in 1903. Over the next forty years, rapid advances were made to improve the technology to make it a viable means of aircraft propulsion. As the technology matured, combustion turbines were adapted to land-based energy generation uses. With the deregulation of the power industry in the 1990s, combustion turbines became the generator of choice for a vast majority of new power projects. Combustion turbines currently have lower capital costs, shorter construction durations and lower operation and maintenance costs than any other large central plant available on the market. The primary constraint to their continued prominence is the current high price of natural gas and diesel fuel.

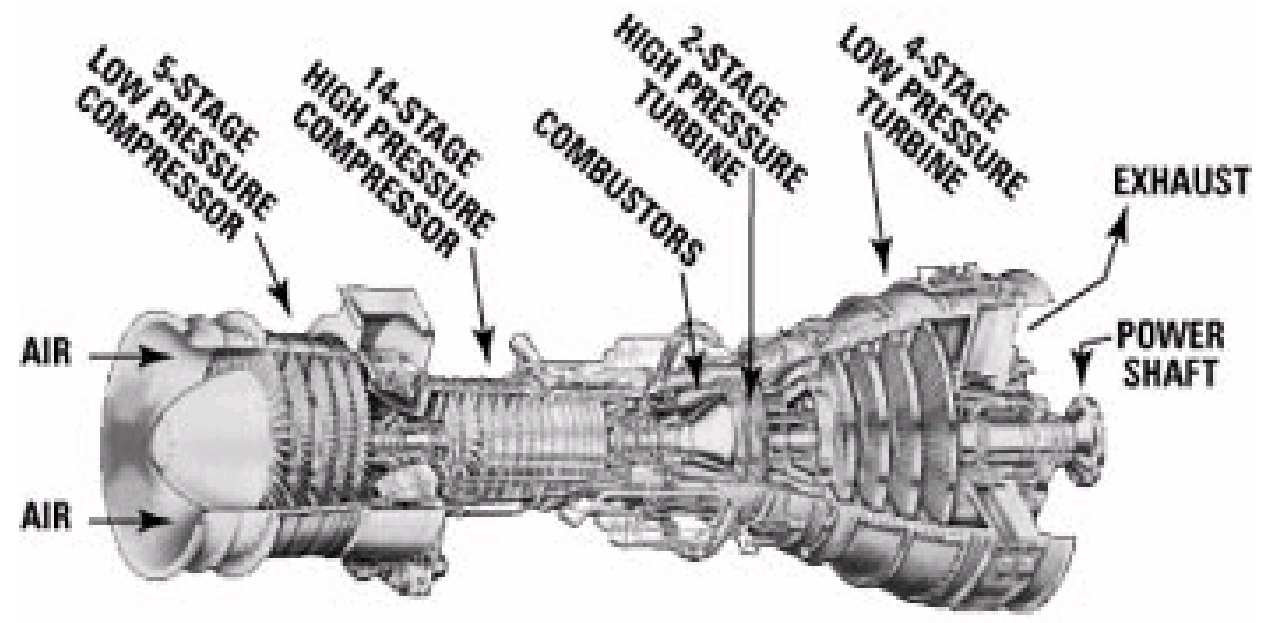

Figure 5-20. Combustion Turbine Section (Source: Langston). 


\subsubsection{Operating Principles}

Power is generated when the combustion turbine compresses ambient air to approximately 12 to 16 atmospheres, heats the pressurized air to $2,000^{\circ} \mathrm{F}$ or more by burning oil, natural gas or renewable fuels, and then expands the hot gas through a turbine. The turbine then drives both the air compressor and an electric generator. A typical combustion turbine would convert 30 to 35 percent of the fuel energy to electric power, with a substantial portion of the fuel energy exhausted in the form of hot $\left(>900^{\circ} \mathrm{F}\right)$ gases exiting the turbine. When the combustion turbine is used to generate power and no energy is captured from the hot exhaust gasses, the power cycle is referred to as a "simple cycle" power plant.

\section{Applications}

Simple cycle combustion turbines are the power generation technology of choice for peaking service in the current domestic power industry. Simple cycle technology provides many of the same positive attributes as reciprocating engines, including rapid startup and modularity for ease of maintenance. In addition, combustion turbines have several advantages over reciprocating engines, including lower emissions and lower capital cost.

\section{Fuel Flexibility}

Like the reciprocating engine, simple cycle turbines are a conventional technology that can be adapted to burn renewable fuels. Simple cycle turbines can burn natural gas, diesel, propane, biogas and some bio-derivative fuels such as biodiesel, ethanol and bio-oil. It should be noted, however, that manufacturers of combustion turbines do not necessarily encourage such fuel flexibility, and burning of alternative fuels may void warranty coverage.

\section{Performance and Cost Characteristics}

Generic performance and cost estimates for small simple cycle combustion turbines are listed in Table 5-8. For reference, the price of fuel is assumed to be $\$ 9 / \mathrm{MBtu}$ equivalent to the current price of natural gas at Viejas. 
Viejas Tribal Government

Renewable Energy Development on Tribal

Lands of Viejas Study

5.0 Renewable Energy Alternatives

Table 5-8. Simple Cycle Combustion Turbine Technology Characteristics.

\section{Commercial Status}

Performance

Net Plant Capacity, kW

Net Plant Heat Rate, Btu/kWh,

Capacity Factor, percent

\section{Economics}

Capital Cost, $\$ / \mathrm{kW}$

Variable O\&M, \$/MWh

Levelized Cost, \$8.8/MBtu Fuel, \$/MWh
Commercial

$300-10,000$

11,000

30-70

1500

$15-25$

150

\subsubsection{Microturbines}

The microturbine is essentially a small version of the combustion turbine. It is typically offered in the size range of 30 to $60 \mathrm{~kW}$. These turbines were initially developed in the 1960's by Allison Engine Co. for ground transportation. The first major field trial of this technology was in 1971 with the installation of turbines in six Greyhound buses. By 1978, the busses had traveled more than a million miles and the turbine engine was viewed by Greyhound management as a technical breakthrough. Since this initial application, microturbines have been used in many applications including small scale electric and heat generation in industry, waste recovery, and continued use in electric vehicles.

\section{Operating Principles}

Microturbines operate on a similar principle to that of larger combustion turbines. Atmospheric air is compressed and heated with the combustion of fuel, then expanded across turbine blades which in turn operate a generator to produce power. The turbine blades operate at very high speed in these units, up to $100,000 \mathrm{rpm}$, versus the slower speeds observed in large combustion turbines. Another key difference between the large combustion turbines and the microturbines is that the compressor, turbine, generator, and electric conditioning equipment are all contained in a single unit about the size of a refrigerator, versus a unit about the size of a rail car. The thermal efficiency of these smaller units is currently in the range of 20 to 30 percent, depending on manufacturer, ambient conditions, and the need for fuel compression; however, efforts are underway to increase the thermal efficiency of these units to around 40 percent. 


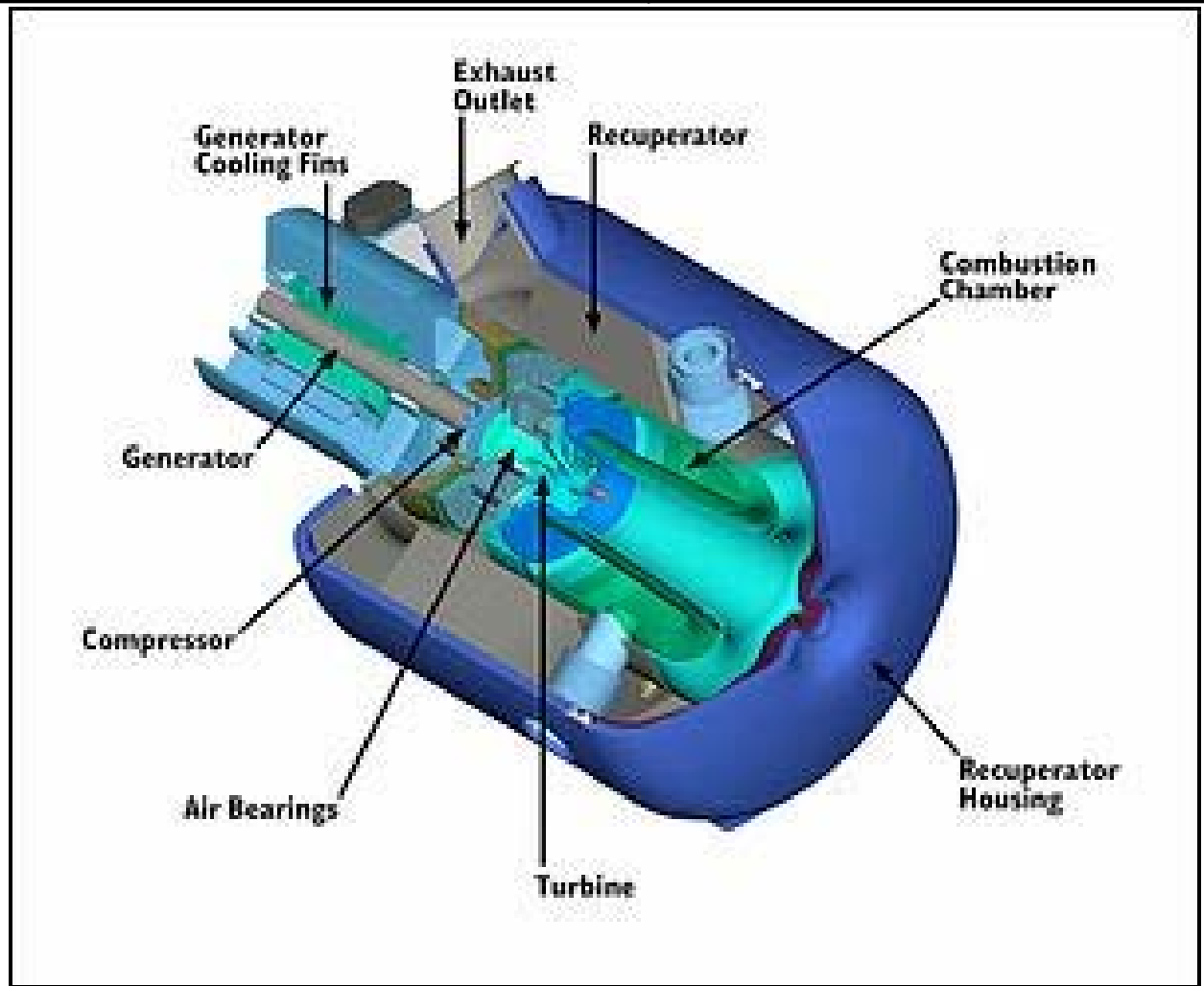

Figure 5-21. Microturbine Cutaway View (Source: Capstone Turbine Corporation.)

\section{Applications}

Potential applications for microturbines are very broad, given the fuel flexibility, size, and reliability of the technology. The units have been used in electric vehicles, distributed generation, and resource recovery applications. These systems have been used in many remote power applications around the world to bring reliable generation outside of the central grid system. In addition, these units are currently being used in several landfill sites to generate electricity with landfill gas fuel to power the facilities on the site. For example, the Los Angeles Department of Water and Power recently installed an array of 50 microturbine generators at the Lopez Canyon landfill. The project has a net output of $1,300 \mathrm{~kW}$.

\section{Fuel Flexibility}

Microturbines offer a wide range of fuel flexibility, with fuels suitable for combustion including: natural gas, ethanol, propane, biogas, and other renewable fuels. The minimum requirement for fuel heat content is around $350 \mathrm{Btu} / \mathrm{standard}$ cubic foot, depending upon microturbine manufacturer. 
Viejas Tribal Government

Renewable Energy Development on Tribal

Lands of Viejas Study

5.0 Renewable Energy Alternatives

Performance and Cost Characteristics

Microturbine costs are often discussed as being about $\$ 1,000$ per kilowatt. However, this is typically just the bare engine cost. Auxiliary equipment, engineering, and construction costs can be significant. Table 5-9 provides performance and cost characteristics for typical microturbine installations. For reference, the price of fuel is assumed to be $\$ 9 / \mathrm{MBtu}$ equivalent to the current price of natural gas at Viejas.

Table 5-9. Microturbine Technology Characteristics.

\begin{tabular}{l|c}
\hline \hline Commercial Status & Early Commercial \\
Performance & \\
$\quad$ Net Capacity per Unit, $\mathrm{kW}$ & $30-250$ \\
Net Plant Heat Rate, Btu/kWh & $12,200-15,000$ \\
Capacity Factor, percent & $30-70$ \\
Economics & \\
Capital Cost, \$/kW* & 2,200 \\
Variable O\&M, \$/MWh & $10-20$ \\
Levelized Cost, \$8.8/MBtu Fuel, \$/MWh & 145 \\
\hline \hline
\end{tabular}

* Average of completed California SELFGEN projects

\subsubsection{Fuel Cell}

Fuel cell technology has been developed by government agencies and private corporations. Fuel cells are an important part of space exploration and are receiving considerable attention as an alternative power source for automobiles. In addition to these two applications, fuel cells continue to be considered for power generation for permanent power and intermittent power demands. Figure 5-22 shows an example of a fuel cell in a distributed generation application. 


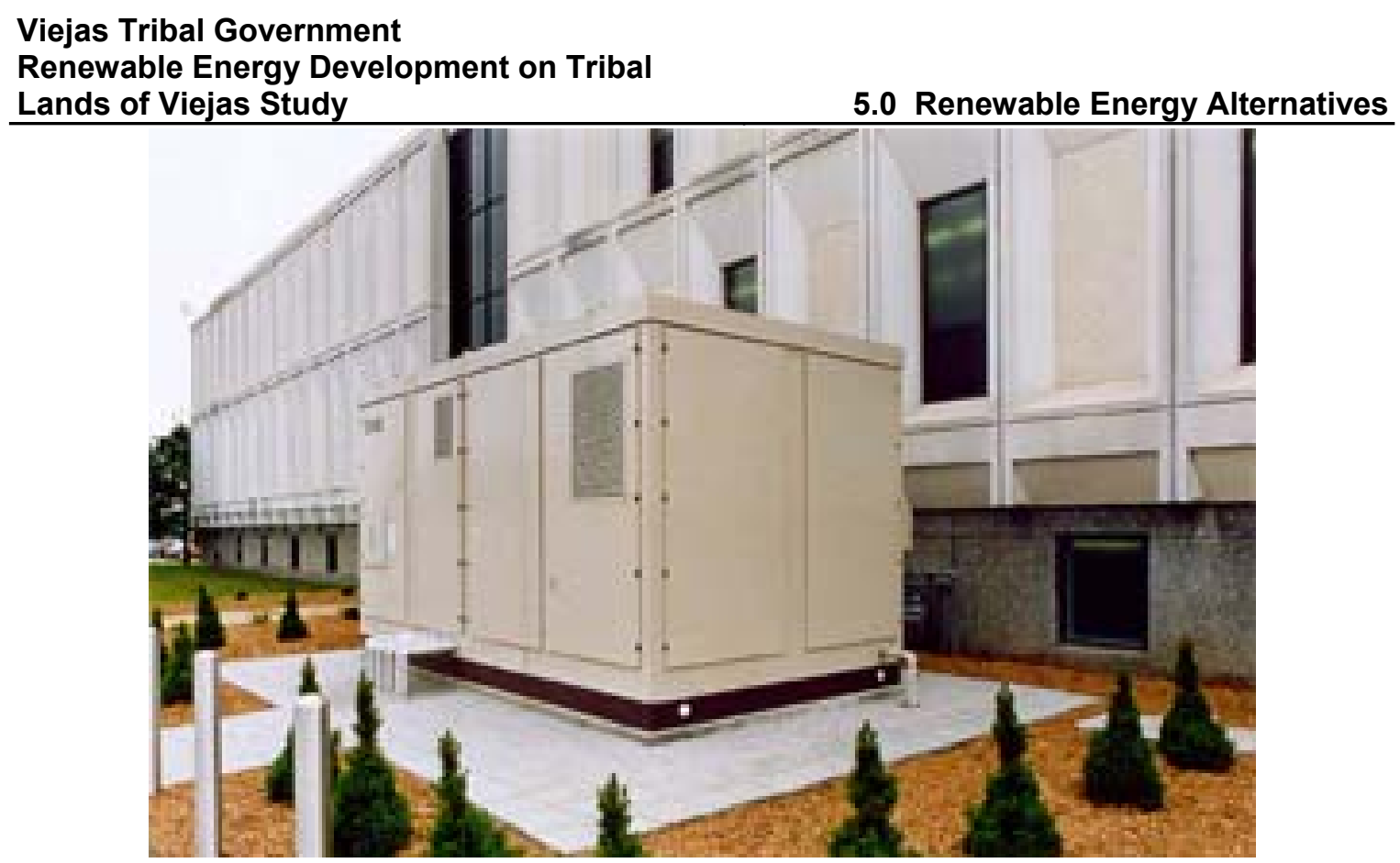

Figure 5-22. 200 kW Fuel Cell (Source: UTC Fuel Cells).

\section{Operating Principles}

Fuel cells convert hydrogen-rich fuel sources directly to electricity through an electrochemical reaction. Fuel cell power systems have the promise of high efficiencies because they are not limited by the Carnot efficiency that limits thermal power systems. Fuel cells can sustain high efficiency operation even under part load. The construction of fuel cells is inherently modular, making it easy to size plants according to power requirements.

There are four major fuel cell types under development: phosphoric acid, molten carbonate, solid oxide, and proton exchange membrane. The most developed fuel cell technology for stationary power is the phosphoric acid fuel cell (PAFC). PAFC plants range from around $200 \mathrm{~kW}$ to $11 \mathrm{MW}$ in size and have efficiencies on the order of 40 percent. PAFC cogeneration facilities can attain efficiencies approaching 88 percent when the thermal energy from the fuel cell is utilized for low grade energy recovery. The potential development of solid oxide fuel cell/gas turbine combined cycles could reach electrical conversion efficiencies of 60 to 70 percent.

\section{Applications}

Most fuel cell installations are less than $1 \mathrm{MW}$. Commercial stationary fuel cell plants are typically fueled by natural gas, which is converted to hydrogen gas in a reformer. However, if available, hydrogen gas can be used directly. Other sources of 
Viejas Tribal Government

Renewable Energy Development on Tribal

Lands of Viejas Study

5.0 Renewable Energy Alternatives

fuel for the reformer under investigation include methanol, biogas, ethanol, and other hydrocarbons.

In addition to the potential for high efficiency, the environmental benefits of fuel cells remain one of the primary reasons for their development. High capital cost, fuel cell stack life, and reliability are the primary disadvantages of fuel cell systems and are the focus of intense research and development. The cost is expected to drop significantly in the future as development efforts continue, partially spurred by interest by the transportation sector.

\section{Performance and Cost Characteristics}

The performance and costs of a typical fuel cell plant are shown in Table 5-10. A significant cost is the need to replace the fuel cell stack every 3 to 5 years due to degradation. The stack alone can represent up to 40 percent of the initial capital cost. Most fuel cell technologies are still developmental and power produced by commercial models is not competitive with other resources. For reference, the price of fuel is assumed to be $\$ 9 / \mathrm{MBtu}$ equivalent to the current price of natural gas at Viejas. In our model we also modeled using wind from a small wind farm to produce hydrogen. The opportunity cost of the fuel came to $\$ 22 / \mathrm{MBtu}$, but the capital cost of the equipment is subsidized by $\$ 4,500 / \mathrm{kW}$ in this scenario. Coincidentally the cost of energy in the two scenarios is approximately equivalent.

Table 5-10. Fuel Cell Technology Characteristics

\section{Commercial Status}

Performance

Net Capacity per Unit, $\mathrm{kW}$

Net Plant Heat Rate, Btu/kWh

Capacity Factor, percent

\section{Economics}

Capital Cost, $\$ / \mathrm{kW}^{*}$

Fixed O\&M, \$/kW-yr**

Variable O\&M, \$/MWh

Levelized Cost, \$8.8/MBtu Fuel, \$/MWh

Levelized Cost, \$22/MBtu Fuel, and \$4.50/W Subsidy, \$/MWh
Development / Early Commercial

100-1000

$7,000-9,500$

30-70

7,700

600

10

300

300

Average of completed California SELFGEN projects

** Includes costs for cell stack replacement every four years. 
Viejas Tribal Government

Renewable Energy Development on Tribal

Lands of Viejas Study

5.0 Renewable Energy Alternatives

5.5.5 Commercial Hot water

Viejas currently has demand for approximately two million BTU/hour of hot water at the Casino's two main boilers. This translates into approximately $400 \mathrm{~kW}$ of generation supplying waste heat to provide the hot water. An engine generator, fuel cell, or micro turbines can be installed to meet this need.

\subsubsection{Commercial Absorption Cooling}

Absorption chillers differ from the more prevalent compression chillers in that the cooling effect is driven by heat energy, rather than mechanical energy. The simplest absorption machines are propane recreational vehicle refrigerators which operate without electricity. An absorption chiller is larger and more complicated, but the basic principle is the same. Lithium bromide-water $(\mathrm{LiBr} / \mathrm{H} 2 \mathrm{O})$ systems are one of the more common systems, with lithium bromide as the absorbent and water as the refrigerant.

In an $\mathrm{LiBr} / \mathrm{H} 2 \mathrm{O}$ absorption chiller an evaporator allows water under vacuum to evaporate absorbing heat. The water is then absorbed into a solution by the hydrophilic absorbent lithium bromide. The combined fluids then go to a generator, which is heated by the heat source (combustion gas, steam, hot oil), boiling the water back out of the absorbent as a gas. The water then goes to a condenser to be cooled back down to a liquid, while the absorbent is pumped back to the absorber. The cooled water is released through an expansion valve into the evaporator, and the cycle repeats.

There is a large capital cost of switching from compressor based chillers to absorption chillers, on the other hand, a 'free' source of heat will likely justify the capital investment. If Viejas decides to operate a megawatt scale thermal generation source switching to absorption chillers at the casino should be investigated more thoroughly. For any new cooling loads looking at absorption chillers with associated thermal generation is recommended.

The current cooling load on the casino is sufficient to utilize the waste heat from a one to three MW combustion turbine or other thermal generation source.

\subsubsection{Sludge Drying}

Sludge being hauled from Viejas is currently estimated to be only one percent dry solids. The other 99 percent is water. Hauling charges are not insignificant. By using waste heat from thermal generation the sludge can be further reduced in an evaporative process. The waste heat from approximately $200 \mathrm{~kW}$ of thermal generation would be sufficient to dry the sludge completely.

A centrifuge drying process will likely bring the dry solids to approximately 20 percent solids and only 150 gallons per day of total sludge. Waste heat from only ten 


\section{Viejas Tribal Government Renewable Energy Development on Tribal Lands of Viejas Study}

5.0 Renewable Energy Alternatives kilowatts of thermal generation would be required to dry this sludge. This small of a system is likely not worth the additional maintenance of a separate small generator but if waste heat from another source is available opportunistic use could be made. Another solution would be to employ an engine driven centrifuge and use the waste heat from the drive engine to dry the sludge. Technical and odor issues may make this use of waste heat to evaporate sludge infeasible. 


\subsection{Energy Storage and Load Management}

\subsection{Energy Storage}

Energy storage technologies convert and store electricity to help alleviate disparities between electricity supply and demand. Energy storage systems increase the value of power by allowing better utilization of off-peak baseload generation and through mitigation of instantaneous power fluctuations. This section presents and discusses the generating descriptions, performance, and cost characteristics of pumped hydro energy storage, battery energy storage, compressed air energy storage, and hydrogen energy storage systems.

\subsubsection{Pumped Hydro}

Pumped hydro energy storage is the oldest and most prevalent of the central station energy storage options. Approximately $22 \mathrm{GW}$ of pumped storage generation is installed in the $\mathrm{US}^{8}$. A pumped storage hydroelectric facility requires a reservoir/dam system similar to a conventional hydroelectric facility. Excess energy from the grid (available at low cost) is used to pump water from a lower reservoir to an upper reservoir above a dam. When energy is required during high cost, peak electrical demand periods, the potential energy of the water in the upper reservoir is converted to electricity as the stored water flows through a turbine to the lower reservoir.

Capital cost and lead time are the primary considerations in implementing this storage technology. Capital costs are typically high on a per $\mathrm{kW}$ basis and a 4 or 5 year construction period for larger pumped storage facility may be expected. Furthermore, it is becoming much more difficult to gain environmental approvals for damming river systems, making the permitting/environmental risk of pumped storage facilities a significant consideration. Geographic and geologic conditions largely preclude many areas from consideration of this technology. Table 6-1 presents typical performance and cost estimates for pumped hydro energy storage.

\footnotetext{
${ }^{8}$ US Department of Energy, EPRI, “Renewable Energy Technology Characterizations,” December 1997.
} 


\begin{tabular}{|l|l|}
\hline \multicolumn{2}{|c|}{ Table 6-1 } \\
\hline \multicolumn{2}{||c||}{ Pumped Hydro Energy Storage - Performance and Costs } \\
\hline Commercial Status & Commercial \\
Construction Period (months) & $12-60$ \\
\hline Performance & $1-1,500+$ \\
\hline Plant Capacity (MW) & $10-40$ \\
Capacity Factor (percent) & $1,550-3,600$ \\
\hline Economics (2004\$) & $5-13$ \\
\hline Total Project Cost $(\$ / \mathrm{kW})$ & $2.5-4.5$ \\
Fixed O\&M (\$/kW-yr) & $140 *$ \\
Variable O\&M $(\$ / \mathrm{MWh})$ & Levelized Cost $(\$ / \mathrm{MWh})$ \\
\hline * Using wind energy valued at $\$ 60 / \mathrm{MWh}$ for pumping \\
\hline
\end{tabular}

\subsubsection{Batteries}

A battery energy storage system consists of the battery, dc switchgear, dc/ac converter/charger, transformer, ac switchgear, and a building to house the components. During peak power demand periods, the battery system can discharge power to the utility system for about 4 to 5 hours. The batteries are then recharged during nonpeak hours. In addition to the high initial cost, a battery system will require replacement every 4 to 10 years, depending on the duty cycle.

Currently, the only commercially available utility size battery systems are lead-acid systems. Research to develop better performing and lower cost batteries such as sodium-sulfur and zinc-bromine batteries is currently underway. The overall efficiency of battery systems averages 72 percent from charge to discharge. The cost and performance of a $5 \mathrm{MW}$ (15 MWh) system is provided in Table 6-2. 


\begin{tabular}{|c|c|}
\hline \multicolumn{2}{|c|}{$\begin{array}{c}\text { Table 6-2 } \\
\text { Lead-Acid Battery Energy Storage - Performance and Costs }\end{array}$} \\
\hline $\begin{array}{l}\text { Commercial Status } \\
\text { Construction Period (months) }\end{array}$ & $\begin{array}{l}\text { Commercial } \\
12-18\end{array}$ \\
\hline \multicolumn{2}{|l|}{ Performance } \\
\hline Plant Capacity (MW) & 5 \\
\hline Energy Capacity (MWh) & 15 \\
\hline Capacity Factor (percent) & $10-15$ \\
\hline \multicolumn{2}{|l|}{ Economics $(2004 \$)$} \\
\hline Total Project Cost $(\$ / \mathrm{kW})$ & $850-1,700$ \\
\hline Fixed O\&M (\$/kW-yr) & 15 \\
\hline Variable O\&M (\$/MWh) & 80 \\
\hline Levelized Cost (\$/MWh) & $250 *$ \\
\hline
\end{tabular}

\subsubsection{Compressed Air Energy Storage}

Compressed air energy storage (CAES) is a technique used to supply electrical power to meet peak loads within an electric utility system. This method uses the power surplus from baseload coal and nuclear plants during off-peak periods or excess wind energy to compress and store air in an underground formation. The compressed air is later heated (with a fuel) and expanded through a gas turbine expander to produce electrical power during peak power demand. A simple compressed air storage plant consists of an air compressor, turbine, motor/generator unit, and a storage vessel (typically underground). Exhaust gas heat recuperation may be added to increase cycle efficiency.

The theoretical basis associated with the thermodynamic cycle for a compressed air storage facility is that of a simple gas turbine system. Typically, gas turbines will consume 50 to 60 percent of their net power output to operate the air compressor. In a compressed air storage generating plant, the air compressor and the turbine are not connected and the total power generated from the gas turbine is supplied to the electrical grid. By using off-peak energy to compress the air, the need for expensive natural gas or imported oil is reduced by as much as two-thirds compared with conventional gas turbines. ${ }^{9}$ This results in a very attractive heat rate for CAES plants, ranging from 4,000 to $5,000 \mathrm{Btu} / \mathrm{kWh}$. Because fuel (typically natural gas) is supplied to the system during

\footnotetext{
${ }^{9}$ Nakhamkin, M., Anderson, L., Swenson, E., “AEC 110 MW CAES Plant: Status of Project,” Journal of Engineering for Gas Turbines and Power, October 1992, Vol. 114.
} 
the energy generation mode, CAES plants actually provide more electrical power to the grid than was used during the cavern charging mode.

The location of a CAES plant must be suitable for cavern construction or for the reuse of an existing cavern. However, suitable geology is widespread throughout the United States with over 75 percent of the land area containing appropriate geological formations. There are three types of formations that can be used to store compressed gases: solution mined reservoirs in salt, conventionally mined reservoirs in salt or hard rock, and naturally occurring porous media reservoirs (aquifers).

The basic components of a CAES plant are proven technologies and CAES units have a reputation for achieving good availability. The first commercial scale CAES plant in the world is a $290 \mathrm{MW}$ plant in Huntorf, Germany. This plant has been operated since 1978, providing 2 hours of generation with 8 hours of charging. In 1991, a $110 \mathrm{MW}$ CAES facility in McIntosh, Alabama, began operation. This plant remains the only US CAES installation, although several new plants have been recently announced. Table 6-3 shows the performance and cost characteristics of a CAES system.

Compressed air energy storage is likely not suitable for smaller gas turbines such as would be suitable for Viejas. Considering the small differential between peak and off peak power, and the large scale of the technology, CAES does not seem to be a good match for Viejas.

\begin{tabular}{|l|l||}
\hline \multicolumn{2}{|c|}{ Table 6-3 } \\
Compressed Air Energy Storage - Performance and Costs \\
\hline Commercial Status & Commercial \\
Construction Period (months) & $26-29$ \\
\hline Performance \\
\hline Plant Capacity (MW) & $100-500$ \\
Net Plant Heat Rate (Btu/kWh) & $4,000-5,000$ \\
Capacity Factor (percent) & $10-40$ \\
\hline Economics $(2004 \$)$ & $480-730$ \\
\hline Total Project Cost $(\$ / \mathrm{kW})$ & $5.30-16.0$ \\
Fixed O\&M $(\$ / \mathrm{kW}-\mathrm{yr})$ & $3.20-6.35$ \\
Variable O\&M $(\$ / \mathrm{MWh})$ & 130 \\
\hline Levelized Cost $\$ / \mathrm{MWh})$ & ${ }^{*}$ Assumed wind energy at $\$ 60 / \mathrm{MWh}$ to compress air \\
\hline
\end{tabular}




\subsubsection{Hydrogen}

A hydrogen-based system is considered as an energy storage system only if the production of hydrogen is part of the overall system. If the hydrogen is supplied as a consumable, then the system is considered as a generator. Typical applications include peak shaving and transmission deferral. A hydrogen-based energy system for distributed generation consists of an electrolyzer, a hydrogen storage pressurized tank, and a fuel cell or a combustion engine. The electrolyzer generates hydrogen using water, as the raw material, through the process of electrolysis. The hydrogen produced is stored in a tank under pressure. Either a fuel cell or a combustion engine can then utilize the hydrogen to generate electricity. The hydrogen energy storage system can generate electricity for a duration of 0.5 to 4 hours and stored energy ranges between 50 and $8,000 \mathrm{kWh} .{ }^{10}$

Electrolyzers are commercially available at various sizes and can generate hydrogen up to a pressure of about $290 \mathrm{psi}^{10}$. An electrolyzer requires water to generate hydrogen via electrolysis. Cooling water is also required in the process. For small remote application, such as for a telecom system, a water storage tank is required on site. For a larger application such as for a residential area, feed water can be extracted from the existing water pipeline. The electorlyzer has a typical efficiency of about 70 percent (lower heating value $)^{11}$. The hydrogen gas produced by the electrolyzer is stored as a pressurized gas at 2,500-3,000 psi using compressors or as a metal hydride. For a small application, compressed gas storage is more cost effective than metal hydride. ${ }^{11} \mathrm{~A}$ suitable fuel cell technology for this type of application is the proton exchange membrane (PEM) fuel cell which operates on hydrogen and air at ambient conditions ${ }^{10}$. The efficiency of PEM fuel cell is about 40-50 percent (lower heating value and based on pure hydrogen fuel) ${ }^{11}$. Alternatively, a combustion engine can be used to burn the hydrogen to generate power with an efficiency of about 44 percent $^{10}$.

A representative performance and cost characteristics of a hydrogen fuel cell are summarized in Table 6-4 based on fuel cell as the power generation technology.

\footnotetext{
${ }^{10}$ Schoenung, S.M. and Hassenzahl, W.V. "Long-vs. Short-Term Energy Storage Technologies Analysis, Life-Cycle Cost Study, A Study for the DOE Energy Storage Systems Program," Sandia Report (SAND2003-2783), printed August 2003.

${ }^{11}$ Cotrell, J. and Pratt, W. "Modeling the Feasibility of Using Fuel Cells and Hydrogen Internal Combustion Engines in Remote Renewable Energy Systems," NREL (NREL/TP-500-34648), September 2003.
} 
Table 6-4

Management

\begin{tabular}{|l|l||}
\hline \multicolumn{2}{|c|}{ Table 6-4 } \\
\multicolumn{2}{|c||}{ Hydrogen Energy Storage - Performance and Costs } \\
\hline \hline Commercial Status & Commercial \\
Construction Period (months) & $3-6$ \\
\hline Performance & $0.1-2$ \\
\hline Plant Capacity (MW) & $7,500-8,000$ \\
Net Plant Heat Rate (Btu/kWh) & $5-70$ \\
Capacity Factor (percent) & $5,000-5,500$ \\
\hline Economics (2004\$) & $350-400$ \\
\hline Total Project Cost (\$/kW) & 340 \\
Fixed O\&M (\$/kW-yr) & Levelized Cost (\$/MWh) \\
\hline$*$ Assumed wind energy at \$60/MWh to electrolyze hydrogen and 40\% efficient fuel cell \\
\hline
\end{tabular}

\subsection{Load Management}

\subsubsection{Dispatchable Loads}

Some electrical loads can provide the same utility to the user independent of when they are dispatched, within a certain time frame. Using this attribute to manage power consumption is called load shifting. Load shifting can be an effective way to match load profile with renewable generation. Loads which may be delayed in time are held off until sufficient generation is present. Three major dispatchable loads have been identified at Viejas, the waste water treatment plant, well pumps, and the central chiller plant.

The waste water treatment plant draws approximately $250 \mathrm{~kW}$ with a load factor of 50 percent and storage for more than a day. Thus the waste water treatment plant can be operated at times of the day when energy is less costly or generated energy is in abundance.

The well pumps have a draw of approximately $150 \mathrm{~kW}$ and have load factors of between 33 and 85 percent. Storage in existing tanks is sufficient for between 12 to 36 hours, depending on the season. Thus the well pumps can be operated to avoid power draw during the most critical hours of the day throughout the year.

The central chiller plant can draw up to $1800 \mathrm{~kW}$ with a load factor of between 15 and 75 percent depending on the season. A certain amount of dispatchability is inherent in the system. On the level of minutes to an hour the deployment of the chillers can be delayed or anticipatively deployed while keeping the building temperature within 
specified bounds. A cold water storage tank could be installed and sized to provide storage in the range of hours. Ice could be employed to store cold for longer periods. Adding storage elements to a system adds cost but these are often less expensive than adding a corresponding dispatchable generation source.

Loads may be dispatched to avoid using power during peak energy cost periods, to use power during periods of peak generation, or to balance overall power demand.

\subsubsection{Energy Efficiency}

One of the best ways to manage load is to simply have the same functions performed with less energy. There is a wide range of opportunity for both business and residential energy users to save energy. Most utilities have programs for educating their rate payers about energy efficient appliances and strategies. San Diego Gas and Electric has several energy efficiency programs and information available on energy efficiency strategies. The SDG\&E website for information on residential programs and strategies is http://www.sdge.com/residential/res energy efficiency.shtml. The website for business programs and strategies is http://www.sdge.com/business/bus_energy_efficiency.shtml.

One effective way to reduce electrical demand is through the use of an electrical services company. Johnson Controls, Inc. (JCI), one such company, is currently is providing Viejas services on the chiller system. A comprehensive look at loads and generation by qualified professionals could identify significant energy savings and load shifting possibilities. These opportunities may be developed within a performance contract where Viejas pays none of the upfront cost but rather a portion of the energy savings goes to paying off the improvements. One possibility would be to have an energy services company and Black \& Veatch work together to identify and implement generation and conservation activities in a complimentary way; with Black \& Veatch providing the renewable energy expertise and the energy services company providing the efficiency know-how and performance contract.

\subsection{Energy Strategy}

If deployed skillfully, load diversion and dispatchable generation can have a greater effect than merely the energy saved, generated, or deferred. By understanding the rules of a billing rate or power purchase agreement, skillful management of energy resources can result in significant savings. 


\subsubsection{Time of Use}

Many billing rates and power purchase agreements use the time of use to determine the value of energy consumed. Typically there will be a peak period and potentially several other periods of the day with different energy charges. This is in contrast to a flat rate in which the same value is placed on electricity around the clock.

Sources of generation, such as solar, have a natural tendency to coincide with afternoon peak periods and thus would be a good match for use with a strong time of use rate. Furthermore Loads may be diverted to off peak times to take advantage of lower rates. Dispatchable generation which may be too expensive to run in a flat rate situation may be cost effective to run during peak periods of the day.

In a net metering arrangement using solar or wind (both are strong producers in the afternoon at Viejas) an extra kilowatt-hour generated during a peak rate time would be more valuable than off peak due to the higher value of energy at peak times.

\subsubsection{Demand Charge Reduction}

Demand charges, or payments based on the maximum electricity demand during a given period, usually monthly or annually, can be a significant cost. If Viejas or one of the Viejas accounts were to draw twice their average demand for even 15 minutes a month the demand charges for that month will be twice what they would have been if demand had been kept level. Such peaks in usage are quite common. Though they do not represent a large percentage of energy consumed they can represent a large portion of a monthly bill. Some billing rates employ time of use demand charges, which vary by time of day, such that capacity payments during off peak periods may be insignificant while avoiding demand charges during peak periods can be quite advantageous. Certain loads that may be able to be diverted for as little as 15 minutes can have a good effect on demand charges.

A generation source that may otherwise be prohibitive to employ may become very valuable if run for only a few hours per month to eliminate peaks in power consumption. Demand charges are calculated based on the maximum power consumed even if it is only for a short period once in the month; this makes effective automatic monitoring and control imperative to implementing a demand charge reduction program. Proper control eliminates the lone mistake which negates the benefit of all efforts put into demand charge reduction for the period.

\subsubsection{Fitting to a Billing Rate}

Different billing rates or power purchase agreements will have widely varying energy charges, demand charges, time of use structure, and other components and 
requirements. Normally it is important to chose the correct billing rate (or negotiate a power purchase agreement) to match load patterns. In the case where one is generating a significant amount of ones own power and has a measure of control of loads it may be advantageous to tailor ones generation to qualify for and take advantage of a given rate. Simulations can be run with Viejas loads and generation sources against different potential billing rates or power purchase agreements to find which Viejas can best take advantage of.

An example of all three of these strategies can be seen at Palmdale Water District's Clear Well pumping station. The pumping station has an average load of approximately $400 \mathrm{~kW}$ and a peak load of near $700 \mathrm{~kW}$. The pumping station qualifies for a very favorable pumping and irrigation rate if its maximum load does not exceed $500 \mathrm{~kW}$. By strategically deploying some load diversion, a small hydro electric generator, and a natural gas reciprocating engine, maximum loads may be kept down below 500kW and significant savings is realized. Furthermore, once the goal of keeping maximum load below $500 \mathrm{~kW}$ has been met, remaining load shifting, hydro, and generator capacity are used to reduce time of use, energy, and capacity charges. 


\subsection{Electrical Interconnection}

As discussed in Section 3.0, Viejas has several energy development options to consider. Each of the three options requires varying levels of electrical interconnection arrangements. A map characterizing each option is located in Appendix B. This section reviews each option and characterizes the interconnection costs of each option. These costs are used to characterize severance scenario costs further evaluated in Section 8.0.

Note that in contrast to the 'Net Metering' planning scenario discussed in Section 3.1 and evaluated in Sections 10 and 13, the following severance scenario evaluates the cost and electrical configuration option Viejas may have available should Viejas choose to form an electric utility. The severance scenarios in Section 7.1 and 7.3 are both sensitivities to the Base Case 'Interconnected Utility' severance scenario evaluated using the financial model in Section 13.2.

\subsection{Net Metering on Individual Accounts}

Net metering is an arrangement with SDG\&E where a renewable generation source on Viejas property feeds forward and backward through the current electrical meter. Viejas is billed only for the net energy consumed over a one year period. California's net metering law allows up to $1 \mathrm{MW}$ of renewable generation per meter to be placed on a net metering rate.

One approach to integrating renewable energy into the Viejas energy mix would be to leave the existing structure and relationship with SDG\&E in place and net meter renewable generation on the reservation. Projects would be scaled to approximately match the annual energy consumption at the meter to which they were interconnected. On a project by project basis it can be decided which are desirable based on economic and other factors.

For accounts where generation will not exceed minimum load, no net metering agreement is necessary, and any generation type may be employed. This assumes that all interconnection, environmental, and safety standards are met.

\subsubsection{Severance Scenario 1 (Net Metering)}

In this severance scenario, Viejas will need to negotiate with SDG\&E and obtain permission to wheel wholesale power through SDG\&E's distribution system. SDG\&E tariffs, CPUC regulations, and other regulations may prohibit the wheeling of wholesale power via distribution lines. In the case that wholesale power is permitted to be wheeled via distribution lines, the distribution system within the Reservation would be purchased 
Viejas Tribal Government

Renewable Energy Development on Tribal

Lands of Viejas Study

7.0 Electrical Interconnection

from SDG\&E, and the energy coming into the system would be primary metered at one location. Another cost consideration incorporated in the model is the distribution cost SDG\&E will charge for Viejas' wheeling of wholesale power via SDG\&E's distribution system. The model assumes a $\$ 0.035 / \mathrm{kwhr}$ charge for wheeling. Table $7-1$ shows the cost components comprising Severance Scenario 1.

Table 7-1. Severance Scenario 1 Cost Breakdown and Estimate

\begin{tabular}{|l|c|}
\hline Net Meter Installation & $\$ 60,000$ \\
\hline Pole Replacement/Additions & $\$ 95,000$ \\
\hline Service cut-overs and change-outs & $\$ 60,000$ \\
\hline Admin, Engineering \& Labor Costs & $\$ 35,000$ \\
\hline Total Estimate & $\$ \mathbf{2 5 0 , 0 0 0}$ \\
\hline
\end{tabular}

Noteworthy items for this scenario are that Viejas will still be under SDG\&E tariffs; and Viejas will be a part of SDG\&E's distribution system.

\subsection{Tribal Utility Interactive with the Grid}

A second option would be formation of a separate utility. The tribal utility would have a wheeling agreement with SDG\&E and power purchase agreements with energy suppliers. The tribal utility would likely operate most of the on-reservation generation. This option is assumed to be the 'Base Case' severance scenario in Section 13.0 Economic Analysis.

\subsubsection{Severance Scenario 2}

Black \& Veatch estimated a $\$ 600,000 /$ mile cost for the construction of a $69 \mathrm{KV}$ transmission line; this amount was used as an input in the model. From a brief site inspection it is assumed that the majority of the Reservation's load would be served by one substation being fed from the $69 \mathrm{KV}$ transmission line. Additional cost considerations will include engineering and distribution work to reconfigure the SDG\&E existing distribution. Table 7-2 shows the components comprising the Interconnected Utility Distribution System Severance Cost. 
Viejas Tribal Government

Renewable Energy Development on Tribal

Lands of Viejas Study

7.0 Electrical Interconnection

Table 7-2. Severance Cost Breakdown and Estimates

\begin{tabular}{|l|c|}
\hline $\begin{array}{l}\text { Building of } 69 \mathrm{KV} \text { Transmission Line to } \\
\text { Reservation }\end{array}$ & $\$ 4,800,000$ \\
\hline New Reservation Sub-station Transformer & $\$ 175,000$ \\
\hline $\begin{array}{l}\text { Feeder Connection from Sub-station to } \\
\text { Viejas Distribution }\end{array}$ & $\$ 60,000$ \\
\hline Pole Replacement/Additions & $\$ 95,000$ \\
\hline Service cut-overs and change-outs & $\$ 60,000$ \\
\hline Admin, Engineering, and other Labor Costs & $\$ 250,000$ \\
\hline Total Estimate & $\mathbf{\$ 5 , 4 4 0 , 0 0 0}$ \\
\hline
\end{tabular}

A detailed study on building a $69 \mathrm{KV}$ transmission line to the reservation will need to be conducted to ascertain firm costs and schedules for this endeavor.

\subsection{Tribal Utility Independent of the Grid}

For the option of forming a utility that is capable of providing all generation needs independent of the outside grid, a connection would likely still be in place. However, an outage or a cost of energy increase on the grid would not necessarily translate into either outage or dramatically increased cost of energy on the reservation.

In this ambitious scenario sufficient generation, storage, and load diverting capability would need to be in place to balance generation and loads on site in absence of the support of the grid. Additional power quality equipment would likely be required. The main advantage of this scenario is self sufficiency, security, and self reliance. Viejas could still interact with the grid, buying and selling power but would not be required to.

\subsubsection{Severance Scenario 3 (Dedicated Distribution Line)}

In this severance scenario Viejas will build a dedicated distribution line leading from the Alpine Substation to the Reservation. The delivery point to the utility will be at the substation; thus, Viejas will not incur any distribution wheeling charge. Table 7-3 shows the cost components comprising Severance Scenario 3. 
Viejas Tribal Government

Renewable Energy Development on Tribal

Lands of Viejas Study

7.0 Electrical Interconnection

Table 7-3. Severance Scenario 3 Cost Breakdown and Estimates

\begin{tabular}{|l|c|}
\hline Building of Dedicated Distribution Circuit & $\$ 196,000$ \\
\hline New Sub-Station Transformer & $\$ 160,000$ \\
\hline Transmission Connection & $\$ 85,000$ \\
\hline Pole Replacement/Additions & $\$ 110,000$ \\
\hline Service cut-overs and change-outs & $\$ 85,000$ \\
\hline Admin, Engineering and other Labor Costs & $\$ 350,000$ \\
\hline Total Estimate & $\mathbf{\$ 9 8 6 , 0 0 0}$ \\
\hline
\end{tabular}




\subsection{Distribution System Audit}

\subsection{Distribution System Overview}

Black \& Veatch performed an audit of the electric distribution system assets located within Viejas Tribal Government land. This audit included visual inspection of all distribution equipment to determine the condition of the assets, and assess their value.

\subsection{Distribution System Condition and Information}

Black \& Veatch's review of the assets determined that the system is in good condition for its age. The majority of the system was installed between the years 1988 and 1995. Underground distribution lines were not inspected as part of the audit.

At the time of the audit, the system included 140 poles of one-phase distribution line, and 102 three-phase line. A review of Viejas Tribal Government land and a mapping of the distribution system were used to estimate how many miles of overhead line are located on the system.

Black \& Veatch estimates eight miles of overhead line on the system. Without access to a detailed map of the system, Black \& Veatch is unable to estimate the length of underground distribution lines. The distribution system valuation methodology is detailed below.

\subsection{Distribution System Valuation}

In general, public utility commissions and courts have recognized four system valuation methodologies. There are:

1. Original Cost Less Depreciation (OCLD) - The OCLD value is based on the actual net book value of the distribution facilities. SDG\&E, when it establishes its rates, recovers the original costs of its facilities through depreciation charges. SDG\&E is then allowed to earn a return on the net book value of the distribution facilities. The OCLD method takes into account the previous customer payments for these distribution facilities. Black \& Veatch requested the original cost of the distribution system in the Viejas Reservation boundary from SDG\&E; SDG\&E did not provide the original cost estimate.

2. Replacement Cost Less Depreciation (RCLD) - The RCLD value is based on the costs of the current facilities as if they were constructed today. RCLD is calculated on the original costs of the distribution facilities escalated to present 


\section{Viejas Tribal Government \\ Renewable Energy Development on Tribal \\ Lands of Viejas Study}

8.0 Distribution System Audit

costs of construction using appropriate cost indices. This replacement cost is then depreciated using SDG\&E's composite distribution system depreciation rate. The RCLD method recognizes, in SDG\&E's favor, that the current distribution facilities would cost more today than when the system was originally built.

3. Reproduction Cost New Less Depreciation (RCNLD) - RCNLD is the cost of reproducing, or constructing, a new distribution system. The primary difference between RCLD and RCNLD is that RCNLD would utilize current technology. The current technology may be more efficient than existing equipment. For the Utility Formation Study performed in 2002, SDG\&E provided a preliminary estimate of the system using this methodology. The estimated price of $\$ 3,000,000$ was based on engineering costs and applied estimates of the average age of the facilities for the determination of depreciation. Further detail is required on SDG\&E's estimated price. This price is ten times higher than Black $\&$ Veatch's estimate. SDG\&E also did not provide any detail on payments contributions Viejas has made on these facilities.

4. Going Concern Value or Discounted Cash Flow Value - RCLD and RCNLD valuations are based on distribution systems' costs. The Going Concern valuation method is based on SDG\&E's earnings from the distribution system. SDG\&E's rates are designed to recover all of SDG\&E's costs in providing distribution service plus a return on the distribution facilities. SDG\&E's cash flow from the system is estimated by determining its annual depreciation expense (which is recovered through rates but does not have a corresponding cash outflow) and its return on equity (profit on the distribution system).

If the Tribal Utility does exercise its right of condemnation, the value of the distribution system most likely would be subject to litigation and would include RCNLD and reasonable reconfiguration costs. SDG\&E has indicated that the distribution system is in good condition and is maintained regularly as a part of the SDG\&E inspection and maintenance program, as required by the CPUC General Order 165. SDG\&E has indicated that the underground system, most of which was built in the last five years, is generally newer than the overhead system. SDG\&E did not provide precise age estimates of the system or components. Therefore, for the purposes of this study, Black \& Veatch used a linear multiplier factor to estimate the value of the distribution assets. Through a cursory visual inspection of SDG\&E's distribution system in the Tribal Utility's territory, the distribution system seems to be relatively new. Therefore, Black \& Veatch also assumed that the valuation RCLD and RCNLD methods would be similar. 
8.3.1 System Cost

\section{OCLD}

The Original Cost Less Depreciation valuation approach takes into consideration the original cost of the system, including poles, lines, transformers, and equipment, and subtracts the accumulated depreciation to obtain a value. SDG\&E did not provide the Reservation's original installed costs of its respective electric distribution system assets nor did it provide an estimated accumulated depreciation of the Viejas System. Therefore, Black \& Veatch employed a linear valuation method using estimated cost per linear mile for the calculation of the OCLD value.

Valuation Assumptions - assumed system to be 10 years old, assumed cost of $\$ 22,000$ per mile of distribution system, assumed 16 miles of distribution circuit within Reservation boundary.

Length of system in Miles

Cost per mile

Cost of System

Less: Accumulated Depreciation (10.0 years/30 years)

Total OCLD Estimate:
16

$\$ 22,000$

$\$ 352,000$

$33.3 \%$

$\$ 234,784$

\section{RCLD}

Building on the estimate calculated above for OCLD, the RCLD can be calculated as follows. Valuation Assumptions - assumed system to be 10 years old, assumed cost of $\$ 22,000$ per mile of distribution system, assumed 16 miles of distribution circuit within Reservation boundary.

OCLD Estimate - From Section 5.5.1

Handy Whitman Index Multiplier

RCLD Estimate
$\$ 234,784$

$\$ 267,889$

The Base Case Distribution System Cost was assumed to be $\$ 270,000$. The sensitivity analysis is as follows:

\section{Going Concern}

The Going Concern, or discounted cash flow, method provides an accurate measure of SDG\&E's ability to earn income from the electric facilities. This method 
estimated the value of the system at approximately $\$ 15.3$ million. Therefore, the Going Concern calculated value is less than the RCLD value and as a result no "added value" for the system.

\subsubsection{Reconfiguration Costs}

Reconfiguration Costs are those costs related to the Tribal Utility reconfiguring its system to operate separately from SDG\&E. From a brief inspection it is assumed that the majority of the Tribal Utility's load will be served by one feeder. Depending on the severance scenario to be determined, SDG\&E will need to confirm. For the Utility Formation Study performed in 2002, Black \& Veatch requested any estimated costs for any severance damages from SDG\&E for the purpose of the study; SDG\&E stated that the information is proprietary and therefore SDG\&E is unable to provide the requested information. Black \& Veatch also requested estimated costs to reconfigure the distribution system for alternative energy deliveries from other sources and the methodology for estimating reconfiguration costs. SDG\&E did not provide any estimates; however SDG\&E did state that any estimate of a reconfiguration cost should include costs of severance from the remaining SDG\&E system and costs associated with interconnection facilities through which power would be delivered to Viejas. Black \& Veatch addresses the issues in three scenario analyses described in Section 7.0. 


\subsection{Legal Analysis}

The Legal Analysis section is included as Appendix D of this report. 


\subsection{Generation Mix Optimization Study}

Black \& Veatch's generation optimization process involves several steps. First, the technologies identified in Section 5.0 of this report are evaluated economically using a Levelized Cost Approach. Then, remaining technologies are further evaluated using Black \& Veatch's software POWROPT, an optimal generation expansion model. Specific scenarios are further evaluated using the production cost model POWRPRO.

The production cost and capital cost results are taken directly from POWRPRO and POWROPT and serve as the cost assumptions for the economic analysis performed in Section 13.0. Figure 10-1 is a flowchart of the Optimization Process.

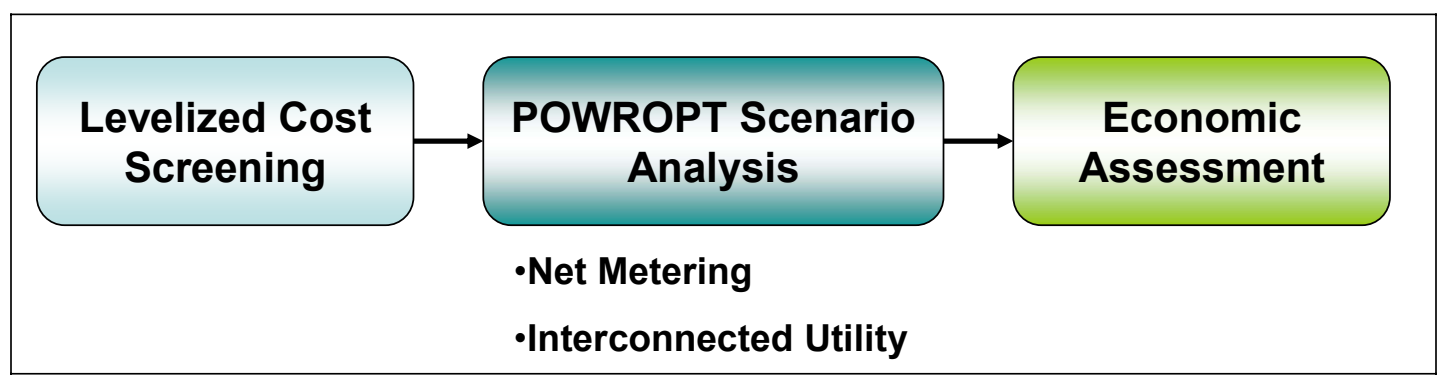

Figure 10-1. Optimization Process

\subsection{Optimization Process}

\subsubsection{Levelized Cost Screening}

The assumptions described in Section 5.0 are used to calculate the Levelized Cost of each Renewable Technology option. The levelized cost is calculated as the average cost in cents/kWh for the life of each technology. Key assumptions used in the calculation include the following:

- Max Output, MW

- Capital Cost

- Debt Term

- Economic Life

- Fixed O\&M, $\$ / \mathrm{kW}-\mathrm{yr}$

- Variable O\&M, \$/MWh

- Capacity Factor
- Production Tax Credit

- Term of Production Tax Credit

- Fuel Cost

- Net Plant Heat Rate

- Discount Rate

- Fixed Charge Rate 
The assumptions are consistent with those used in the economic analysis performed in Section 13.0. Each technology's levelized cost is calculated using the above assumptions, as well as the range of potential capacity factors for each technology.

The results are used to screen out technologies that will not be selected by POWROPT. This screening allows the optimization model to converge to an optimal solution in a manageable timeframe. Black \& Veatch screened out technologies that, based on the assumptions used, would not be competitive with (a) the prices currently being paid for power through SDG\&E and (b) the other technology options under evaluation.

\subsection{Planning and Production Costing Methodology}

The supply-side evaluations of generating unit alternatives were performed using POWROPT, an optimal generation expansion model. POWROPT, developed by Black \& Veatch, has been benchmarked against other optimization programs and has proven to be an effective modeling program. POWROPT, and its production costing module POWRPRO, have both been used in numerous power supply planning and integrated resource plan engagements across the country.

POWROPT, which operates on an hourly chronological basis to determine a set of optimal capacity expansion plans, simulates the operation of each of the expansion plans, and selects the most desirable plan based on cumulative present worth revenue requirements. POWROPT evaluates all combinations of generating unit alternatives and purchase power options while maintaining user-defined reliability criteria. All capacity expansion plans were analyzed over the 20 year period from 2006 through 2025.

After the optimal generation expansion plan was selected using POWROPT, Black \& Veatch's detailed chronological production costing program, POWRPRO was used to obtain the annual production cost for the expansion plan. POWRPRO is a computer based chronological production costing model developed for use in power supply systems planning. POWRPRO simulates the hour-by-hour operation of a power supply system over the specified planning period. Required inputs are carried forward from those used in POWROPT and include the performance characteristics of generating units, fuel costs, and the system hourly load profile for each year.

POWRPRO summarizes each unit's operating characteristics for every year of the planning horizon. These characteristics include, among others, each unit's annual generation, fuel consumption, fuel cost, average net operating heat rate, the number of hours the unit was on-line, the unit's capacity factor, variable O\&M costs, the number of starts and associated fuel costs. Fixed O\&M costs are also included for new unit additions. The operating costs of each unit are aggregated to determine annual operating 
Viejas Tribal Government

Renewable Energy Development on Tribal

Lands of Viejas Study

10.0 Generation Mix Optimization Study

costs for each year of the expansion plan, and capital costs, fixed O\&M, fixed costs for natural gas transportation, and capacity charges associated with new unit additions and new purchase power alternatives are then added. The cumulative present worth cost (CPWC) of each expansion plan is then calculated.

The CPWC calculation accounts for annual system costs (fuel and purchased energy costs, fixed and variable non-fuel O\&M, purchase power capacity charges and other fixed charges, natural gas transportation charges, and levelized capital costs) for each year of the expansion planning period and discounts the costs back to 2006 at the present worth discount rate of 5.5 percent. These annual present worth costs are then summed over the 20 year period to calculate the total CPWC cost of the expansion plan being considered. Such analysis allows for a comparison of CPWC between various capacity expansion plans, and the plan with the lowest CPWC is considered the least-cost capacity expansion plan.

\subsection{Key Assumptions Overview}

The Generation Technology Assumptions developed in Section 5.0 were used to characterize the performance and cost assumptions for each option evaluated in the optimization process.

The Annual Energy Profile developed in Section 3.0 is another key assumption used in the optimization model. Black \& Veatch's Load model was used to take the typical 8,760 hour energy profile for Viejas, and grow it annually. The peak demand and energy for each year is consistent with the assumptions in Section 3.3.

In evaluating wind technologies, the wind data analyzed in Section 5.0 was used to evaluate different wind technologies. Annual 8,760 hour wind energy curves were developed as an input to POWRPRO.

In evaluating solar technologies, the solar data analyzed in Section 5.0 was used to evaluate technologies. Annual 8,760 hour solar energy curves were developed as an input to POWRPRO.

\subsection{Levelized Cost Screening Results}

Figure 10-2 shows the range of likely Levelized Cost for each technology. The ranges are driven by the potential range in annual capacity factor, as well as cost assumptions. Important assumptions used in this analysis include:

- For wind technologies, capacity factors were calculated using the wind data collected as part of this project and detailed in Section 5.1.

- Solar capacity factor assumptions are consistent with the analysis performed in Section 5.2. 
- All financial assumptions are consistent with those used in Section 13.0, Economic Assessment.

- The fuel cost assumptions for the Microturbine Cogeneration option take into account the value of waste heat from the turbine that would be used to offset current heating load.

- The fuel cost assumptions for the conventional gas simple cycle option assume that a portion of the waste heat generated by the turbine is used to offset current heating load.

- The abbreviation SGIP stands for Self Generation Incentive Program, a California program, funded by the PUC, which provides capital cost incentives for investment in self generation.

- The Pumped Hydro levelized costs are dependent on the Small Wind Farm option being implemented in tandem. The Stand Alone Utility Planning Scenario will require redundant generation sources that minimize the probability of loss of load. Therefore, the combination of a small wind farm and pumped hydro would be considered for this planning scenario. These options are not evaluated in either the Net Metering or Interconnected Utility planning scenarios.

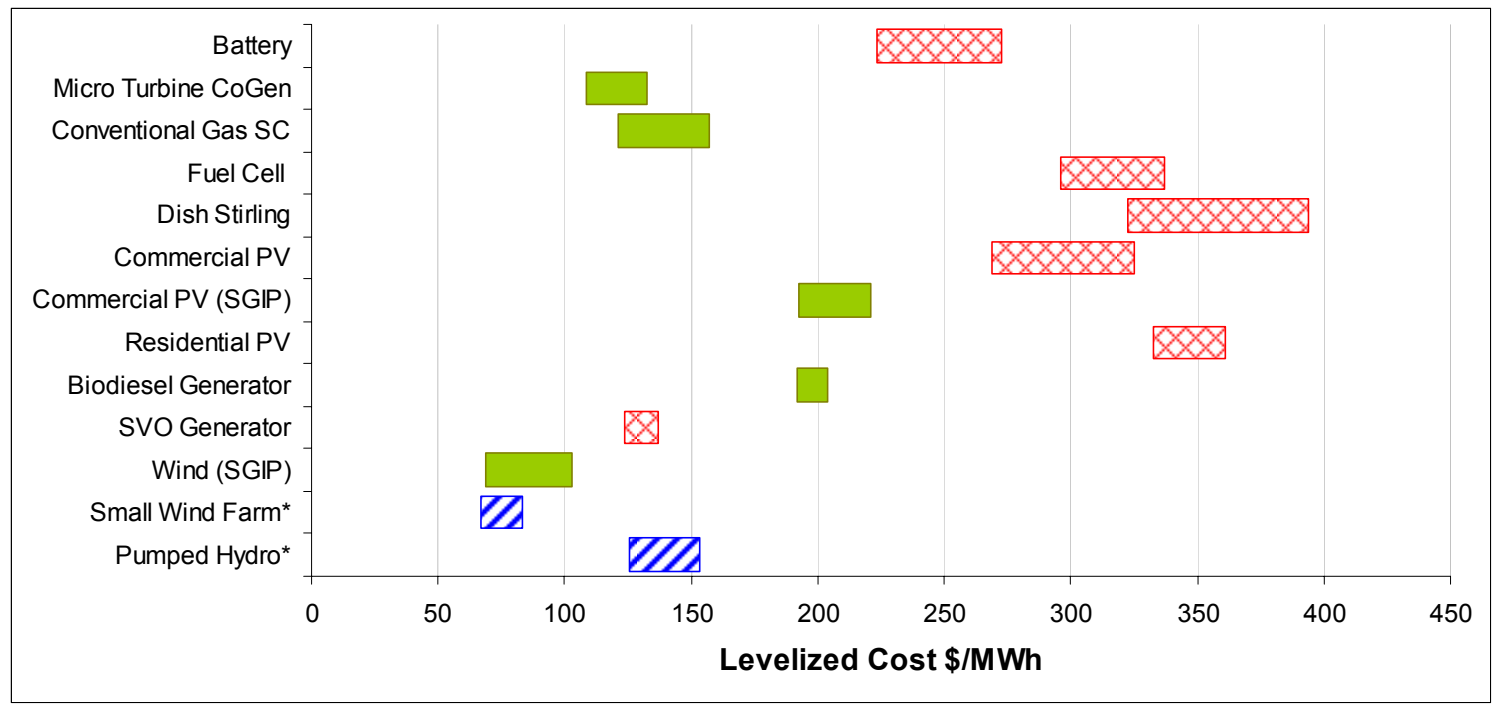

Considered in Optimization Model

Not Evaluated in Optimization Model

Considered for Stand Alone Utility Scenario Only

Figure 10-2. Levelized Cost Results

* The assumptions used for the Small Wind Farm and Pumped Hydro are dependent on both technologies being installed on the El Capitan Reservation. 
Based on the assumptions used, the levelized cost of the technologies highlighted in checkered red are uneconomic in comparison to the other options, as well as in comparison to the rates Viejas is currently paying for electricity. Therefore, these options were not evaluated further in the optimization process.

While the economics of the SVO Biofuel technology are promising, since it is currently an unproven generation technology, it was not considered as a viable option for the optimization process. However, should thermal generation sources be pursued by Viejas in the future, this technology does merit investigation.

\subsection{Evaluation of Planning Scenarios}

Two planning scenarios were evaluated within the optimization model. These included scenarios for the following two strategic options discussed in Section 3.0:

- Net Metering

- Interconnected Utility

In discussions with Viejas Tribal Government, it was decided that there was a low probability of siting renewable generation on the Capitan Grande Reservation. Since the siting of generation on the Capitan Grande Reservation would likely be required to viably develop a Stand Alone Utility, this option was not evaluated using the optimization model.

\subsubsection{Net Metering}

For the net metering planning scenario, in addition to the renewable technology generation options, the optimization model also has the option to purchase electricity from SDG\&E. The rate assumed for these purchases is equivalent to the weighted average aggregate price Viejas currently pays SDG\&E, inclusive of Energy and Demand charges. This aggregate rate was calculated using recent billing information to be 11.4 cents per kWh.

Analysis of Viejas demand data identified three meters with high usage that would lend them to an effective net metering situation. These meters include the following:

\begin{tabular}{|l|c|c|l|}
\hline $\begin{array}{l}\text { Account } \\
\text { Number }\end{array}$ & Meter Number & $\begin{array}{c}\text { Meter } \\
\text { Abbreviation }\end{array}$ & Name \\
\hline 9678664455 & 1818617 & $\mathrm{~A}$ & VIEJAS CASINO \& TRF CLB \\
\hline 655391861 & 1667537 & $\mathrm{~B}$ & VIEJAS CASINO \& TRF CLB \\
\hline 3882914171 & 1751731 & $\mathrm{C}$ & VIEJAS CASINO \& TRF CLB \\
\hline
\end{tabular}


Meter ' $A$ ' has had an annual average demand of over 1 MW historically. Meters ' $\mathrm{B}$ ' and ' $\mathrm{C}$ ' as they will be referred to in this section, both have average annual demand of over $400 \mathrm{~kW}$, with peak levels significantly higher than this average level.

As Figure 10-2 demonstrates, only one renewable generation technology's levelized cost is less than the 11.4 cent/kWh weighted average cost of electricity. Therefore, for the base case net metering planning scenario assumptions, the only generation technology with the potential for a positive cash flow is wind generation. The following three wind turbine net metering scenarios were further analyzed in the Economic Assessment:

- A single $1 \mathrm{MW}$ wind turbine, net metering against Meter A

- Two $1 \mathrm{MW}$ wind turbines, net metering against Meters A \& B

- Three $1 \mathrm{MW}$ wind turbines, net metering against Meters A, B, and C

These scenarios were simulated using the POWRPRO production cost model. The results of these production cost model simulations are used as cost inputs in the economic analysis performed in Section 13.0. The policies governing both net metering and the SGIP program do have limits to what can be done at a single site or by a single owner. How these rules apply to these three meters was not specifically analyzed at this time. The study assumes all three turbines receive the SGIP capital cost credit. The two and three turbine scenarios should be considered contingent on meeting the regulatory requirements governing the program.

\subsubsection{Interconnected Utility}

The optimization model was used to evaluate the option of developing a utility that is interconnected with the grid. The technology options that were economically competitive based on the levelized cost screening analysis were further evaluated using POWROPT.

In contrast to the Net Metering option, for this planning option all of Viejas' demand is aggregated. The options that the optimization model has to choose from to serve the demand include the viable renewable technology options, as well as purchased electricity available from the grid.

The assumed price for purchased power is 6.87 cents per $\mathrm{kWh}$ in 2005 . This price does not include any cost of CDWR premiums. These premiums are described more fully in Section 13.0 as they are one of the risk factors evaluated in the Economic Assessment.

As Figure 10-2 demonstrates, none of the renewable technology option levelized costs are less than the 11.4 cents per kWh currently being paid for electricity to SDG\&E. 


\section{Viejas Tribal Government Renewable Energy Development on Tribal Lands of Viejas Study}

10.0 Generation Mix Optimization Study

Two options with the potential for greater economic viability include the combination of a pumped hydro facility and small wind farm installed near the Capitan Grande Reservoir. Due to jurisdictional and political issues, this site was not evaluated for this feasibility study.

As a result, the optimal base case interconnected utility plan is to purchase electricity at the purchased power rate of 6.87 cents per $\mathrm{kWh}$ for all of Viejas' requirements. This plan was simulated using POWRPRO and the results used as inputs to the economic analysis section. 


\subsection{Environmental Assessment}

\subsection{Wind}

Wind is a clean generation technology from the perspective of emissions. However, there are environmental considerations associated with wind turbines. First, opponents of wind energy frequently cite visual impacts as a drawback. Some turbines are approaching and exceeding 300 feet tall, and for maximum efficiency tend to be located on ridgelines and other elevated topography. Combining turbines of different type, manufacturer, color and rotation can increase the visual impact of turbine developments. Second, turbines can cause avian fatalities if they are located in areas populated by native birds or on migratory flyways. To some degree, these issues can be partially mitigated through proper siting, environmental review, and the involvement of the public during the planning process.

\subsection{Solar}

A key attribute of solar PV cells is that they are virtually non-polluting after installation. Some thin film technologies have potential for discharge of heavy metals in manufacturing; however, this issue is being adequately addressed through proper monitoring and control. Compared to emissions from conventional fossil fuel technologies, these impacts are generally inconsequential. The main impact of large PV installations is occupation of land area. This problem is avoided with rooftop and parking structure installations.

\subsection{Biodiesel}

When compared to petroleum diesel, biodiesel offers a variety of benefits. Testing has shown that biodiesel has lower sulfur emissions and particulate emissions than regular diesel fuel. Not only does biodiesel emit few harmful gases when combusted, but in almost every circumstance, fewer greenhouse gases are emitted in the production and transportation of biodiesel than are released in the production, transportation, and refinement of petroleum diesel. In addition to the aforementioned benefits, biodiesel boasts higher full-fuel cycle efficiency.

Straight vegetable oil (SVO), while still being a carbon neutral fuel and sharing most of the emission reduction characteristics of biodiesel, does have greater particulate and un-burnt carbon emissions than biodiesel. Whether using biodiesel, SVO, or natural 
gas the air quality impacts and regulations will need to be addressed as an early step in their development.

\subsection{Pumped Hydro}

Pumped hydro has the potential to impact fish populations in either the upper or lower reservoir. Proper screening to exclude fish from being drawn into pumps and turbines can eliminate most of this impact. The upper reservoir may have extreme variations in level depending on its volume in comparison to use patterns. The creation of an upper reservoir in Capitan Grande reservation will require flooding of an area of land. This could be seen as an impact or an environmental positive through adding aquatic habitat, though the quality of that habitat will be compromised due to the varying reservoir levels.

\subsection{Cleveland National Forrest}

The renewable energy technology options considered in this feasibility study will have little or no effect on the Cleveland National Forest, with the following exceptions:

- Development of a pumped hydro facility will have minor effects on lake levels in the Capitan Grande Reservoir, and effects on fish in the reservoir will need to be addressed in the design of the pump intake system.

- A pumped hydro or wind farm installation within the Capitan Grande Reservation will require road and transmission access across the Cleveland National Forest. Road and transmission tower installation can have some erosion and visual impact effects on the national forest.

- A wind farm on the Capitan Grande Reservation will impact the view from high points within Cleveland National Forest.

- Any thermal generation will have some level of air quality impact to the surrounding area. 


\subsection{Tribal Benefit Assessment}

The purpose of the Tribal Benefit Assessment is to evaluate the impacts of renewable energy development choices to the tribe for the following issues:

- Employment

- Cultural

- Social

The potential of developing renewable energy on Viejas land was assessed for these issues to ensure it aligns with Viejas Tribal values and to evaluate the influence of development on the tribe.

\subsection{Employment}

One potential tribal benefit to renewable energy installations is employment. A tribal utility requires trained staff and sound management to carry out distribution system operations and maintenance (O\&M). O\&M operations include repairs and replacement of the components, such as lines, cables, poles, transformers, that make up the distribution system. Additional operations are tree trimming, vegetation control, new service/expanded service construction, and emergency restoration services.

The Tribal Government may elect to develop its own crews, contract with private companies, or contract with neighboring utilities for the performance of O\&M responsibilities.

In addition to the care of the distribution system, the Tribal Government will need to provide customer service and billing services. Plans must be made for the provision of basic customer services such billing, collections, meter reading, new account establishment and discontinuance of service. Again, the Tribal Government may elect to provide its own personnel to perform these services and incorporate the systems with those used for water management or contract with other parties. Because of the small size of the utility's client base, the lack of internal mechanisms for O\&M and customer service, and the close proximity of contractible resources, this evaluation assumes that the Tribal Government will contract the entire operation with a third party supplier. 
Viejas Tribal Government

Renewable Energy Development on Tribal

Lands of Viejas Study

\subsection{Cultural Issues}

One of Viejas' cultural values includes the Right of Self Determination. Investment in and operation of energy production facilities, specifically renewable technology, aligns with this value. Many of the technologies evaluated in this study allow the tribe to gain varying degrees of energy independence. Fuel sources for many of the renewable technologies are inherent in nature and decrease the impact that fossil fuel and electric market volatility have on Tribal Energy Usage and Cost. Greater energy independence allows the tribe greater control over its future energy decisions.

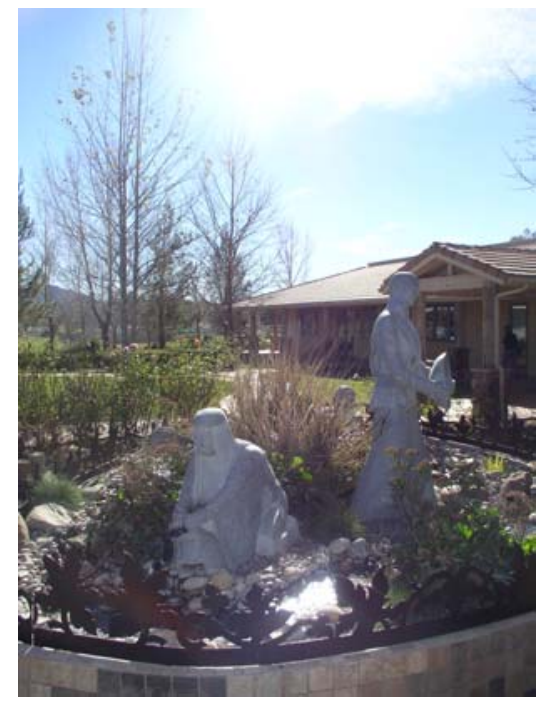

\subsection{Social Issues}

The issue of environmental stewardship is one directly and significantly affected by energy usage. Investment in renewable energy sources decreases the demand for fossil-fuel fired electric generation, which releases greater amounts of emissions into the environment. Tribal reliance on renewable energy sources ensures that tribal energy consumption is contributing to a more healthy and safe environment, one of Viejas' tribal values.

Renewable energy provides tribal educational opportunities for the tribe and its neighbors. One way to promote this education would be the development of a Renewable Energy Education Center.

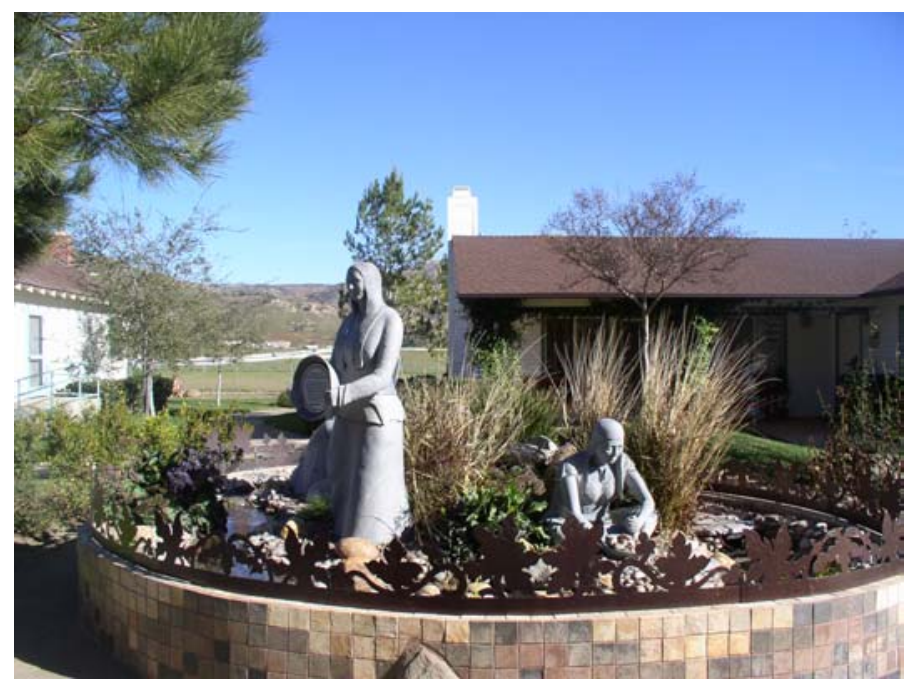




\subsection{Economic Assessment}

Black \& Veatch investigated the feasibility of Viejas acquiring the portion of SDG\&E's electric distribution system within Tribal Government borders, in order to provide power cost savings to the Tribal Utility's customers. This section outlines the feasibility of the two planning scenarios discussed in Section 10.5. The financial models used for the two evaluations are included in Appendix $\mathrm{C}$ of this report.

\subsection{Economic Assessment of Planning Scenarios}

\subsubsection{Net Metering Planning Scenario}

As discussed in Section 10.5, the following three scenarios were evaluated economically using the financial model:

- A single $1 \mathrm{MW}$ wind turbine, net metering against Meter A

- Two $1 \mathrm{MW}$ wind turbines, net metering against Meters A \& B

- Three $1 \mathrm{MW}$ wind turbines, net metering against Meters A, B, and C

The results of the Net Metering Planning Scenario analysis indicate that of the three scenarios, the option to install three $1 \mathrm{MW}$ wind turbines for net metering against Viejas' largest three meters has the highest 10 year Net Present Value (NPV). Under this scenario's Base Case, the 10-year cash flow analysis yields an NPV of $\$ 651,000$. Risk factors to this scenario are evaluated in Section 13.2.1.

While the base case analysis for the three turbine scenario yields the largest NPV, Black \& Veatch notes that the policies governing both net metering and the SGIP program do have limits to what can be done at a single site or by a single owner. How these rules apply to these three meters was not specifically analyzed. The study assumes all three turbines receive the SGIP capital cost credit. The three turbine scenario should be considered contingent on meeting the regulatory requirements governing the program.

The following tables show the 10 year NPV results for one and three turbines, respectively, in addition to the capital costs for each option.

\begin{tabular}{|l|c|c|}
\hline Option & 10 Year NPV & Capital Cost (after SGIP) \\
\hline Net Metering -1 WT & $\$ 223,000$ & $\$ 700,000$ \\
\hline Net Metering -3 WT & $\$ 651,000$ & $\$ 2,100,000$ \\
\hline
\end{tabular}




\subsubsection{Interconnected Utility Planning Scenario}

Black \& Veatch analyzed the Tribal Utility's proposed purchase of the electric distribution system using a cash flow model. Black \& Veatch started its analysis by establishing a Base Case Scenario. This Scenario establishes the most likely case with market and load data provided at the time of this report.

The 10 year net present value cash flow analysis shows that for the base case assumptions used, the formation of an electric utility is not economically viable. The base case scenario for the economic assessment assumes no renewable generation is installed by Viejas. For the interconnected utility planning scenario, the base case yields the most attractive 10 year NPV when compared to the renewable generation alternatives. The 10 year NPV for this base case is negative $\$ 1,929,000$.

While the 10 year NPV is negative, the base case utility formation scenario does have a positive net present value in year twenty-two. Utility formation risk factors for this base case scenario are evaluated in Section 13.2.2.

\subsection{Sensitivity Analysis}

\subsubsection{Net Metering Sensitivity Analysis}

Many of the risk factors of forming a tribal utility do not apply to a net metering plan. Table 13-1 lists each of the risk factors evaluated for the base case net metering option, as well as their low and high sensitivity values.

Table 13-1. Net Metering Base Case Input Assumptions.

\begin{tabular}{|l|c|c|c|}
\hline Parameter & Base Case & Low & High \\
\hline Supply Costs (\$/kWh) & 1.14 & 1.083 & 1.197 \\
\hline Debt Financing (\%) & 8 & 7 & 9 \\
\hline Discount Rate (\%) & 5.5 & 4.5 & 6.5 \\
\hline Rate Increase/(Decrease) (\%) & 0 & $-5 \%$ & $+5 \%$ \\
\hline $\begin{array}{l}\text { Wind Turbine Capacity Factor } \\
\text { (Net Metering Option) }\end{array}$ & $13 \%$ & $8 \%$ & $16 \%$ \\
\hline
\end{tabular}

Base Case Net Metering (3 WT) 10 Year NPV: \$651,000

The sensitivity analysis shows that the major financial impact for the Tribal Utility to the base case net metering scenario is wind turbine capacity factor, as shown in Figure 13-1. Black \& Veatch recommends continued monitoring of wind data using the anemometers, as discussed in Section 5.1. 
Model Parameters

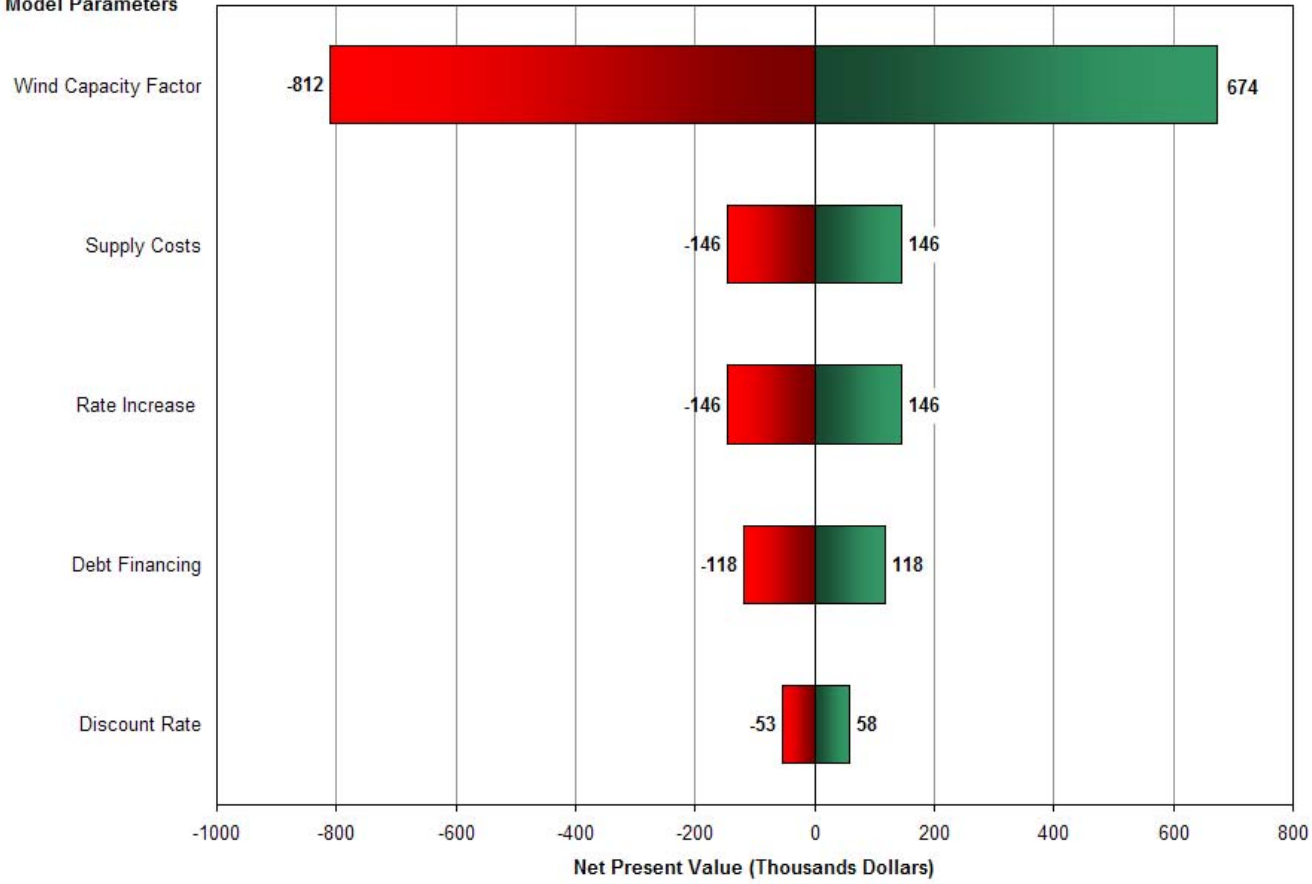

Figure 13-1. 10 Year Net Metering Net Present Value (NPV).

\subsubsection{Interconnected Utility Sensitivity Analysis}

Black \& Veatch analyzed the Tribal Utility's proposed purchase of the electric distribution system using a 10-year cash flow model. Black \& Veatch then established the parameters for which sensitivity analyses would be performed. A high and low case Scenario was developed for each of the parameters. These parameters are discussed in detail in the Utility Formation Study performed for Viejas by Black \& Veatch in 2002.

Each Scenario was compared to the Base Case to determine its specific impact to the Base Case model run. A summary of the list of parameters and the high/low Scenarios is outlined in Table 13-2, Model Input Assumptions. 
Table 13-2. Model Input Assumptions.

\begin{tabular}{|l|c|c|c|}
\hline Parameter & Base Case & Low & High \\
\hline Supply Costs (\$/kW) & 0.0687 & 0.05496 & 0.92135 \\
\hline $\begin{array}{l}\text { Value of System (\$) (excluding } \\
\text { legal fees) }\end{array}$ & $\$ 270,000$ & $\$ 234,000$ & $\$ 355,000$ \\
\hline Growth Rate In MWh (\%) & 1.7 & 1.1 & 2.5 \\
\hline Growth Rate In Customers (\%) & 3.0 & 2.1 & 3.9 \\
\hline Debt Financing (\%) & 8 & 7 & 9 \\
\hline Inflation Capital Replacement (\%) & 1.50 & 1.00 & 2.00 \\
\hline Discount Rate (\%) & 5.5 & 4.5 & 6.5 \\
\hline Reconfiguration Costs (\$) & $5,440,000$ & 250,000 & 986,000 \\
\hline $\begin{array}{l}\text { Operation \& Maintenance (2002 } \\
\text { Contract Year) }\end{array}$ & 300,000 & 150,000 & 450,000 \\
\hline $\begin{array}{l}\text { Operation \& Maintenance Cost } \\
\text { Escalation (\%) }\end{array}$ & 1.0 & 0.5 & 1.5 \\
\hline Rate Increase/(Decrease) (\%) & 0 & $-5 \%$ & $+5 \%$ \\
\hline Legal Expenses (\$) & $2,500,000$ & $1,500,000$ & $3,000,000$ \\
\hline Capital Replacement (\%) & 3.5 & 3.0 & 4.0 \\
\hline Public Goods Charge & $0 \%$ & $0 \%$ & $2 \%$ \\
\hline $\begin{array}{l}\text { Wind Turbine Capacity Factor } \\
\text { (Net Metering Option) }\end{array}$ & $13 \%$ & $8 \%$ & $16 \%$ \\
\hline
\end{tabular}

Base Case 10 Year NPV: $\quad(\$ 1,929,000)$

The following chart summarizes the impact of each parameter to the Base Case NPV. The chart is split into two sections, Model Parameters and Regulatory Risks. Model Parameters shows the impact of varying operating and purchase price parameters to the Base Case. The bottom part of the chart shows the impact of Regulatory Risks associated with the Utility effort. The Base Case NPV of $(\$ 1,929,000)$ is shown on the chart as 0.00 . 


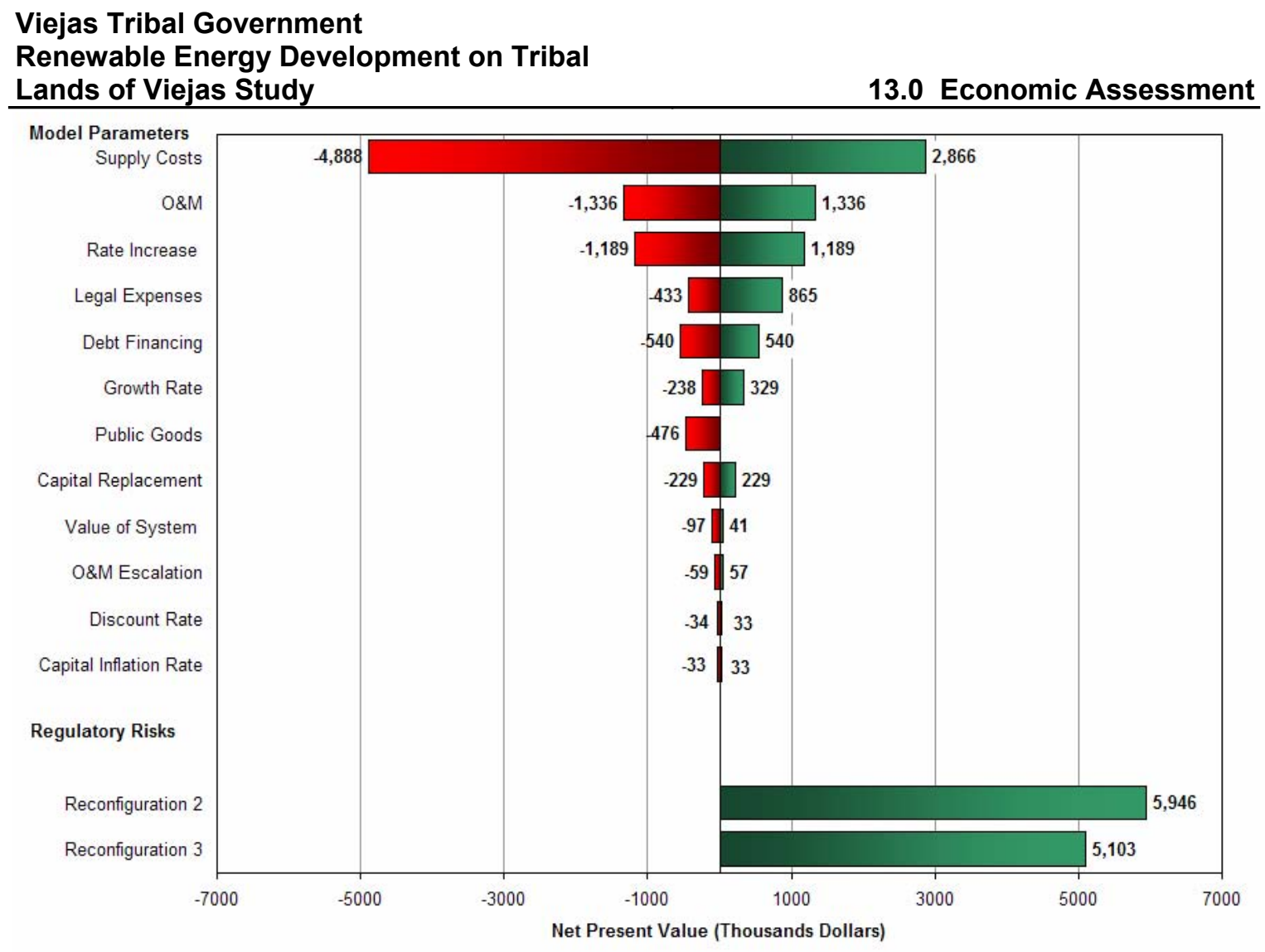

Figure 13-2. 10 Year Utility Net Present Value (NPV).

The major financial impacts for the Tribal Utility to form an electric utility are, in order of maximum NPV impact: Energy Supply Costs (Note that the High Case includes 'Stranded Costs' from DWR contracts), Operations \& Maintenance, Rate Increase, and Reconfiguration Costs 2 and 3. Each parameter is discussed in the Utility Formation Study performed for Viejas Tribal Government by Black \& Veatch in 2002.

The largest NPV driver for the base case scenario is Supply Costs. The base case financial model indicates that supply costs of $\$ 59 / \mathrm{MWh}$ or less would yield a positive 10 year net present value. 


\subsection{Business Plan}

The following section outlines a path toward greater energy self reliance for Viejas. The path has three distinct stages. In the first stage, energy efficiency and load dispatch improvements are made as well as energy generation on an individual meter-bymeter basis. The second stage involves creating an electrical utility, coordinating energy dispatch activities between meters and installing central generation. In the third stage, Viejas would add sufficient generation and storage to meet all of the reservation's electrical needs and even export energy to the grid. These provide a potential implementation plan on the path to self generation. Section 14.4 is an outline of a traditional business plan suitable for this type of endeavor.

\subsection{Self Generation/Net Metering Projects}

A straight forward initial step to energy self sufficiency is to implement some smaller to mid-sized generation projects. These projects should be the most economical and politically feasible projects. Load reduction and load management projects are likely to be the most economical projects. The feasibility analysis indicates wind turbine projects at the site of major loads will likely have a comparable cost of energy to current electric rates. Though not providing the least expensive energy solar PV is very well accepted in the community and the non-economic value of PV installation(s) may merit their inclusion for early development.

Several next steps are identified should Viejas choose to pursue this planning scenario:

- Identify and implement cost effective energy efficiency projects

- Identify and implement economical load management strategies

- Begin pre-development of wind project

- Get quotes for wind turbine installation and select contractor

- Install wind turbine(s)

- Engineering Design

- Power Agreement

○ Permitting and Licensing

- Project Financing

- Hardware Development

- Construction and Training

- Commissioning

- Operations \& Maintenance 
- Identify and evaluate potential solar PV projects.

- $\quad$ Select and implement PV project(s)

\subsection{Utility Formation}

Should Viejas choose to form a tribal electric utility, it will be possible to negotiate a bulk power agreement for the entire reservation. Furthermore load management across the entire reservation is possible as well. In addition, generation at a particular site is no longer limited to the consumption at that particular meter. With the formation of a utility, installation of a small natural gas (or waste vegetable oil) fired combustion turbine may have advantages, especially if use can be made of the waste heat. A SCADA system to enable generation and load dispatch will be helpful for Viejas in managing a utility. The following steps should be taken, should Viejas choose to form an electric utility:

- Issue a Request for Proposals for power supply to the new electric Utility

- Obtain a legal opinion on the optimal electric utility structure and condemnation process

- Investigate opportunities to include additional adjacent electric load

- Issue a Request for Proposals for operation, maintenance, and customer service support for the new electric utility

- Develop a communications plan for the community to explain issues, process and reasons why Viejas is proceeding with forming an electric Utility

- Investigate:

- Absorption Chillers and other waste heat users

○ Load and Generation Integration

- Additional Renewable Technology at Quality Sites

\subsection{Self Sufficiency}

It will be expensive to obtain energy self sufficiency using renewable energy sources on the Viejas reservation. The wind resource is marginal and though the solar resource is very good, the cost to develop solar electricity is high. Unless biomass would be imported from off site, renewable dispatchable generation or energy storage will also be expensive.

It may be that product advancement, or strong incentives will make development of a large scale solar thermal electric plant at Viejas attractive in the future.

It has been indicated that Viejas may at some point in the future gain rights to develop the Capitan Grande Reservation. The Capitan Grande Reservation has two 
Viejas Tribal Government

Renewable Energy Development on Tribal

Lands of Viejas Study

14.0 Business Plan

features which would increase the viability of a self sufficient Viejas Renewable Energy

Tribal Utility. First, the wind resource is much better than on the valley floor, making a commercial wind farm viable. Second, access to the Capitan Grande reservoir would enable construction of a pumped hydro storage facility with a water storage pond constructed on high ground within the Capitan Grande Reservation. In this scenario wind energy would be the primary energy source for the reservation. Pumped water would store energy to be released when the wind is not blowing.

General steps to achieve an energy self-sufficient Viejas through development of a wind farm and pumped hydro storage facility are listed below.

- Create conceptual design

- Build community support

- Identify requirements and begin permitting

- Identify customer(s) for excess energy begin negotiations

- Identify contractors for wind farm and hydro construction, get bids

- Construct wind farm and hydro facility

- Connect output to Viejas grid

- Maintain and operate system

\subsection{Business Plan Outline}

It will be beneficial to the development of renewable energy at Viejas for the Public Works Department, with Black \& Veatch support, to build a business plan including elements from the outline below based on this report, continuing Black \& Veatch support, and tribal member and government input once a direction has been decided on.

- Statement of Purpose

- Tribal Electric Utility

- Description of the Utility

- Legal structure

○ Functions

- Personnel

- Management

- Communications Plan

- Financing

- Financial Forecast

○ Expenses

- Revenue 
Viejas Tribal Government

Renewable Energy Development on Tribal

Lands of Viejas Study

Appendix A. Bio-Fuel Specifications

Appendix A. Bio-Fuel Specifications 


\section{Information Release Memo}

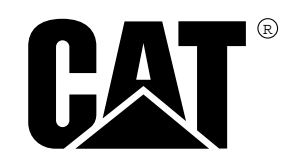

\section{Preventive \\ Maintenance Products}

March 2001

\section{CATERPILLAR POSITION ON THE USE OF BIODIESEL FUEL}

This document applies, within the stated limitations, to Caterpillar engines.

\section{Introduction:}

With increased world interest in emissions and reducing the use of petroleum distillate based fuels, many governments and regulating bodies encourage the use of biofuels. Governmental incentives and/or environmental legislation to use biofuels may have an impact on the sales and use of Caterpillar engines and equipment. This document outlines Caterpillar's criteria and parameters when using biodiesel fuel.

Biodiesel is a fuel that can be made from a variety of sources, primarily from soybean oil or rapeseed oil. Without esterification, these oils gel in the crankcase and fuel tank and may not be compatible with many of the elastomers used in today's engines. In their original form, these oils are not suitable for use as a fuel in compression ignition engines. To use these oils as fuel, they must be esterified. Alternate base stocks for biofuel may include animal tallow, waste cooking oils, or a variety of other feedstocks.

ASTM has recently authored a provisional specification for biodiesel, PS121. Caterpillar recognizes BioFuels meeting the ASTM PS121, DIN 51606 or the Caterpillar biodiesel specification.

Caterpillar certifies its engines using the prescribed EPA and European Certification Fuels. Caterpillar does not certify engines on any other fuel. It is the user's responsibility to use the correct fuel as recommended by the manufacturer and allowed by EPA or other local regulatory agencies. It is the responsibility of the user to obtain the proper local, regional, and/or national exemptions required for the use of biodiesel in any emissions regulated Caterpillar engine. 


\section{Warranty and the Use of Biodiesel Fuel in Caterpillar Engines}

Caterpillar neither approves nor prohibits the use of biodiesel fuels. Caterpillar is not in a position to evaluate the many variations of biodiesel fuels, and the long-term effects on performance, durability or emissions compliance of Caterpillar products. The use of biodiesel fuel does not affect Caterpillar's materials and workmanship warranty. Failures resulting from the use of any fuel are not Caterpillar factory defects and therefore the cost of repair would NOT be covered by Caterpillar's warranty.

\section{$\underline{\text { Recommendation for the use of Biodiesel Fuel in Caterpillar Engines }}$}

For Caterpillar 3046, 3064, 3066, 3114, 3116, 3126, 3176, 3196, 3208, 3306, C-10, C-12, 3406, C-15, C-16, 3456, 3408, 3412, 3500 series, 3600 series, CM20, CM25 and CM32 engines: Biodiesel meeting the requirements listed in Caterpillar's biodiesel specification or, meeting either ASTM PS121 or DIN 51606, are acceptable. They may also be blended in any percentage with an acceptable diesel fuel, provided the biodiesel constituent meets the requirements outlined in the Table prior to blending.

For Caterpillar 3003 through 3034, 3054 and 3056 engines: Biodiesel meeting the requirements listed in Caterpillar's biodiesel specification, or meeting either ASTM PS121 or DIN 51606, may be blended with an acceptable diesel fuel at a maximum of 5\% biodiesel fuel blended with $95 \%$ diesel fuel. The biodiesel must meet the requirements outlined in the Table prior to blending. Use of more than a 5\% biodiesel fuel can cause premature failures whose repair would not be covered under Caterpillar warranty.

When burning biodiesel, or any blend of biodiesel, it is the responsibility of the user to obtain the proper local, regional, and/or national exemptions required for the use of biodiesel in any emissions regulated Caterpillar engine. When using a fuel that meets the Caterpillar's Biodiesel specification, ASTM PS121, or DIN 51606 specifications, and when adhering to the following recommendations, the use of biodiesel should pose no problems. 


\section{$\underline{\text { Recommendations: }}$}

$>$ The oil change interval can be affected by the use of biodiesel fuel. Use Scheduled Oil Sampling (SOS) to monitor the engine oil condition and to determine the optimum oil change interval.

$>$ Biodiesel provides approximately 5-7\% less energy per gallon of fuel when compared to distillate fuels. To avoid engine problems when the engine is converted back to $100 \%$ distillate diesel fuel, do not change the engine rating to compensate for the power loss.

$>$ Elastomer compatibility with biodiesel is still being monitored. The condition of seals and hoses should be monitored regularly.

$>$ Biodiesel fuels may pose low ambient temperature problems for both storage and operation. At low ambient temperatures, fuel may need to be stored in a heated building or a heated storage tank. The fuel system may require heated fuel lines, filters, and tanks. Filters may plug and fuel in the tank may solidify at low ambient temperatures if precautions are not taken. Consult your biodiesel supplier for assistance in the blending and attainment of the proper cloud point fuel.

$>$ Biodiesel has poor oxidation stability, which can result in long term storage problems. The poor oxidation stability qualities may accelerate fuel oxidation in the fuel system. This is especially true in engines with electronic fuel systems because they operate at higher temperatures. Consult the fuel supplier for oxidation stability additives.

$>$ Biodiesel fuel is an excellent medium for microbial growth. Microbes cause fuel system corrosion and premature filter plugging. The effectiveness of conventional anti-microbial additives, when used in biodiesel is not known. Consult your fuel and additive supplier for assistance.

$>$ Care must be taken to remove water from fuel tanks. Water accelerates microbial growth. Water is naturally more prevalent in biodiesel fuels than in distillate fuels. 


\section{Caterpillar Biofuel Specification}

\begin{tabular}{|c|c|c|c|c|}
\hline Property & Test Method & Test Method & Units & Limits \\
\hline & United States & International & Fuel Specific Properties & \\
\hline Density @ $15^{\circ} \mathrm{C}$ & ASTM D1298 & DIN/ISO 3675 & $\mathrm{~g} / \mathrm{cm}^{3}$ & $0.86-0.90$ \\
\hline Viscosity @ 40 $\mathrm{C}$ & ASTM D445 & DIN/ISO 3104 & $\mathrm{~mm}^{2} / \mathrm{s}$ & $4.0-6.0$ \\
\hline Flash Point & ASTM D93 & DIN/ISO 22719 & ${ }^{\circ} \mathrm{C}$ & $100 \mathrm{~min}$ \\
\hline $\begin{array}{cl}\text { Cold Filter Plugging } \\
- & \text { Summer } \\
- & \text { Winter }\end{array}$ & ASTM D4539 & DIN EN 116 & ${ }^{\circ} \mathrm{C}$ & $\begin{array}{l}0 \\
6 \text { below ambient }\end{array}$ \\
\hline $\begin{aligned} & \text { Pour Point } \\
&- \text { Summer } \\
&- \text { Winter }\end{aligned}$ & ASTM D97 & ISO 3016 & ${ }^{\circ} \mathrm{C}$ & $\begin{array}{l}-9 \max \\
-20 \max \end{array}$ \\
\hline Sulfur Content & ASTM D2622 & ISO 8754 & $\%$ weight & $0.01 \max$ \\
\hline $\begin{array}{l}\text { Distillation } \\
-\quad 10 \% \text { Evaporation } \\
-\quad 90 \% \text { Evaporation }\end{array}$ & ASTM D1160 & ISO 340 & ${ }^{\circ} \mathrm{C}$ & $\begin{array}{l}\text { To Be } \\
\text { Determined } \\
345\end{array}$ \\
\hline Carbon Residue, Conradson (CCR) & ASTM D189 & DIN/ISO 10370 & $\%$ weight & $0.5 \max$ \\
\hline Cetane Number & ASTM D613 & ISO 5165 & & $45 \mathrm{~min}$ \\
\hline Ash Content & ASTM D482 & $\begin{array}{l}\text { DIN } 51575 \\
\text { ISO } 6245\end{array}$ & $\mathrm{mg} / \mathrm{kg}$ & $0.02 \max$ \\
\hline Water Content & ASTM D1796 & $\begin{array}{c}\text { DIN51777-1 } \\
\text { ISO3733 }\end{array}$ & $\mathrm{g} / \mathrm{m}^{3}$ & $500 \max$ \\
\hline Particulate Matter & DIN 51419 & DIN 51419 & & 15 \\
\hline Copper Corrosion & ASTM D130 & DIN/ISO 2160 & & No.1 \\
\hline Oxidation Stability & ASTM D2274 & IP 306 mod. & $\mathrm{mg} / 100 \mathrm{~mL}$ & $15 \max$ \\
\hline Esterification & & & $\%$ volume & $98.0 \mathrm{~min}$ \\
\hline Acid Value & ASTM D664 & DIN 51558 & $\mathrm{mg} \mathrm{NaOH} / \mathrm{g}$ & $0.5 \max$ \\
\hline Methanol Content & GC Method & DIN 51608 & $\%$ weight & $0.2 \max$ \\
\hline Monoglycerides & GC Method & DIN 51609 & $\%$ weight & $0.8 \max$ \\
\hline Diglycerides & GC Method & DIN 51609 & $\%$ weight & $0.2 \max$ \\
\hline Triglycerides & GC Method & DIN 51609 & $\%$ weight & $0.2 \max$ \\
\hline Free Glycerin & GC Method & DIN 51609 & $\%$ weight & $0.02 \max$ \\
\hline Total Glycerin & GC Method & DIN 51609 & $\%$ weight & $1.2 \max$ \\
\hline Iodine Number & $\begin{array}{l}\text { DIN } 53241 \text { or } \\
\text { IP } 84 / 81\end{array}$ & $\begin{array}{c}\text { DIN } 53241 \text { or IP } \\
84 / 81\end{array}$ & $\mathrm{cg} \mathrm{I}_{2} / \mathrm{g}$ & $110 \max$ \\
\hline Phosphorus Content & DGF C-VI4 & DIN 51440-1 & $\mathrm{mg} / \mathrm{kg}$ & 0.2 \\
\hline
\end{tabular}

Maintenance Products and Services Group

Product Support Division

LC2172 - 309-636-5136

This IRM can be viewed and downloaded electronically from the Internet. Please refer to your marketing organization specific site for access to the Electronic Sales Library which contains all of the active IRMs

and product support communication materials.

Electronic Sales Library

NACD Dealers - https://nacd.cat.com/infocast/frames/machine/doc/

CSARL Dealers - https://cosa.cat.com/infocast/frames/literatur/external-link/

CACO Dealers - https://caco.cat.com/infocast/frames/PSE/media/esl/

CofA Dealers - https://cofa.cat.com/infocast/frames/SalesTools/SalesLib/

Cat Asia Dealers - https://catasia.cat.com/infocast/frames/mktgcom/elecsale/

Internal Caterpillar Employees - http://cat-mcsd-02.cis.cat.com/multimedia/PSMprev.nsf/\$\$ModelSearch 


\section{Bio oll speciffcation for Wärtsilä four-stroke engines}

\begin{tabular}{|c|c|c|c|}
\hline Property & Unit & Limit & $\begin{array}{l}\text { Test method } \\
\text { reference }\end{array}$ \\
\hline Viscosity, max. & cSt @ $40^{\circ} \mathrm{C}$ & 100 & ISO 3104 \\
\hline Viscosity, min. & cSt & $1.8-2.8^{1)}$ & ISO 3104 \\
\hline Injection viscosity, max. & cSt & 24 & ISO 3104 \\
\hline Density, max. & $\mathrm{kg} / \mathrm{m}^{3} @ 15^{\circ} \mathrm{C}$ & 991 & ISO 3675 or 12185 \\
\hline Ignition properties & & 2) & FIA test \\
\hline Water, max. before engine & $\%$ volume & 0.20 & ISO 3733 \\
\hline Carbon residue (micro method), max. & $\%$ mass & 0.30 & ISO 10370 \\
\hline Flash point (PMCC), min. & ${ }^{\circ} \mathrm{C}$ & 60 & ISO 2719 \\
\hline Pour point, max. & ${ }^{\circ} \mathrm{C}$ & 3) & ISO 3016 \\
\hline Cloud point, max. & ${ }^{\circ} \mathrm{C}$ & 3) & ISO 3015 \\
\hline Cold filter plugging point, max. & ${ }^{\circ} \mathrm{C}$ & 3) & IP 309 \\
\hline Total sediment existent, max. & $\%$ mass & 0.05 & ISO 10307-1 \\
\hline Sulphur, max. & $\%$ mass & 0.05 & ISO 8754 \\
\hline Ash, max. & $\%$ mass & 0.05 & ISO 6245 \\
\hline Phosphorus, max. & ppm & 100 & ISO 10478 \\
\hline Silicon, max. & ppm & 10 & ISO 10478 \\
\hline Alkali content $(\mathrm{Na}+\mathrm{K})$, max. & ppm & 30 & ISO 10478 \\
\hline Copper strip corrosion, max. & $3 \mathrm{hrs} @ 50^{\circ} \mathrm{C}$ & $1 b$ & ASTM D130 \\
\hline Steel corrosion, max. & $\begin{array}{l}\text { 24/72 hrs @ } \\
20,60 \text { and } 120^{\circ} \mathrm{C} \\
\end{array}$ & $\begin{array}{l}\text { No signs } \\
\text { corrosion }\end{array}$ & LP 2902 \\
\hline Acid number, max. & $\mathrm{mg} \mathrm{KOH} / \mathrm{g}$ & 5.0 & ASTM D664 \\
\hline Strong acid number, max. & $\mathrm{mg} \mathrm{KOH} / \mathrm{g}$ & 0.0 & ASTM D664 \\
\hline Iodine number, max. & & 120 & ISO 3961 \\
\hline
\end{tabular}

\section{4-stroke Technology}




\section{Appendix B. Electrical Interconnections}

\section{Net Metering}

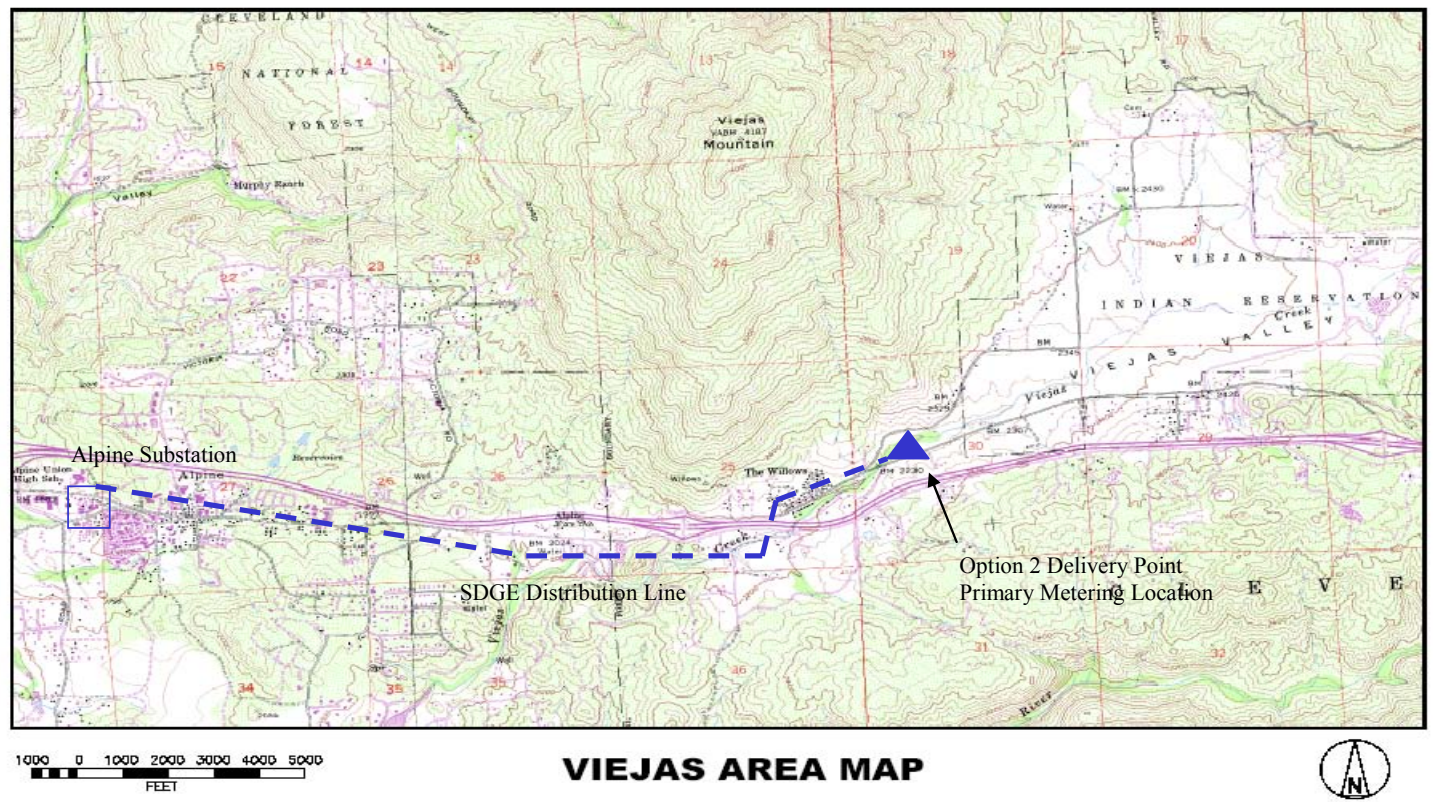




\section{Interconnected Utility}

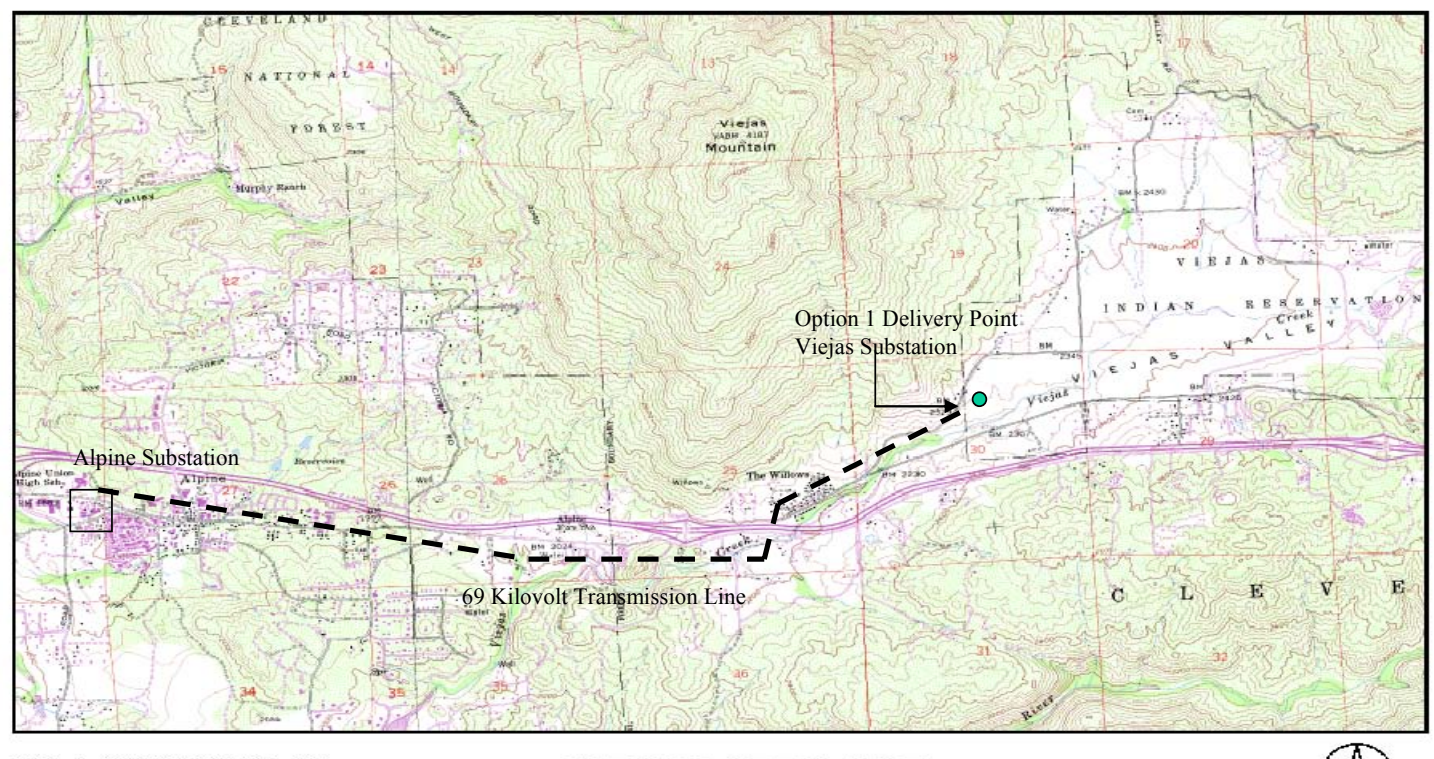

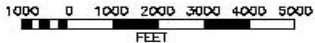

VIEJAS AREA MAP

\section{Stand Alone Utility - Dedicated Distribution Line}

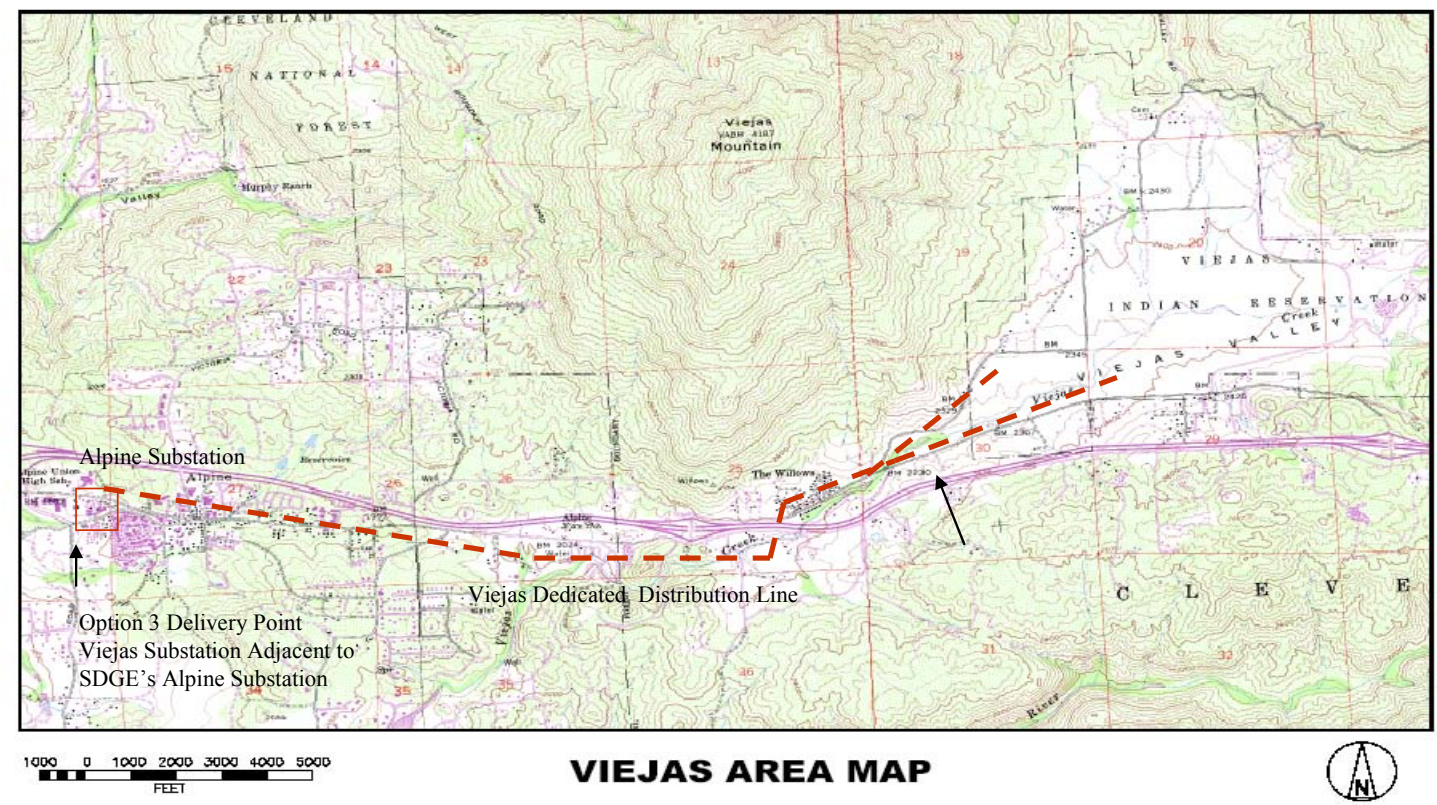




\section{Appendix C. Base Case Cash Flow Analyses}

\begin{tabular}{|c|c|c|c|c|c|c|c|c|c|c|}
\hline Operating Year & 1 & 2 & 3 & 4 & 5 & 6 & 7 & 8 & 9 & 10 \\
\hline \multicolumn{11}{|l|}{ Revenues $(\$ 000)$} \\
\hline Operating Revenues & 2,738 & 2,832 & 2,929 & 3,030 & 3,133 & 3,241 & 3,352 & 3,467 & 3,586 & 3,709 \\
\hline Other Income & 97 & 97 & 97 & 97 & 97 & 97 & 97 & 97 & 97 & 97 \\
\hline Total Revenues & 2,835 & 2,929 & 3,026 & 3,126 & 3,230 & 3,338 & 3,449 & 3,564 & 3,683 & 3,806 \\
\hline \multicolumn{11}{|l|}{ Expenses $(\$ 000)$} \\
\hline Power Supply & 2,467 & 2,556 & 2,649 & 2,745 & 2,844 & 2,946 & 3,052 & 3,162 & 3,276 & 3,394 \\
\hline $\mathrm{O} \& \mathrm{M}$ & 54 & 55 & 57 & 58 & 60 & 61 & 63 & 64 & 66 & 67 \\
\hline Property Taxes & 0 & 0 & 0 & 0 & 0 & 0 & 0 & 0 & 0 & 0 \\
\hline Franchise Fee & 0 & 0 & 0 & 0 & 0 & 0 & 0 & 0 & 0 & 0 \\
\hline Total Expenses & 2,521 & 2,612 & 2,706 & 2,803 & 2,903 & 3,007 & 3,115 & 3,226 & 3,342 & 3,461 \\
\hline Net Operating Income (\$000) & 314 & 317 & 320 & 324 & 327 & 330 & 334 & 337 & 341 & 345 \\
\hline \multicolumn{11}{|l|}{ Debt Service (\$000) } \\
\hline Principle & 72 & 72 & 72 & 72 & 72 & 72 & 72 & 72 & 72 & 72 \\
\hline Interest & 170 & 164 & 158 & 153 & 147 & 141 & 135 & 130 & 124 & 118 \\
\hline Total Debt Service & 242 & 236 & 230 & 225 & 219 & 213 & 207 & 202 & 196 & 190 \\
\hline Debt Service Reserve Fund & 216 & 220 & 225 & 229 & 234 & 239 & 243 & 248 & 253 & 258 \\
\hline Debt Reserve Interest & 4 & 4 & 4 & 5 & 5 & 5 & 5 & 5 & 5 & 5 \\
\hline Capital Outlays (\$000) & 0 & 0 & 0 & 0 & 0 & 0 & 0 & 0 & 0 & 0 \\
\hline Funds Net DS & $(140)$ & 85 & 94 & 104 & 113 & 122 & 131 & 141 & 150 & 160 \\
\hline \multicolumn{11}{|l|}{ Income Taxes } \\
\hline Utility Tax (City Ordinance) & 0 & 0 & 0 & 0 & 0 & 0 & 0 & 0 & 0 & 0 \\
\hline St. Tax/Other & 0 & 0 & 0 & 0 & 0 & 0 & 0 & 0 & 0 & 0 \\
\hline Total Income Taxes & 0 & 0 & 0 & 0 & 0 & 0 & 0 & 0 & 0 & 0 \\
\hline Net Available Funds & $(140)$ & 85 & 94 & 104 & 113 & 122 & 131 & 141 & 150 & 160 \\
\hline Net Present Value - $10 \mathrm{Yr}$ & 651 & & & & & & & & & \\
\hline Debt Service Coverage Ratio & 1.30 & 1.34 & 1.39 & 1.44 & 1.49 & 1.55 & 1.61 & 1.67 & 1.74 & 1.81 \\
\hline
\end{tabular}

Fig. C-1. Base Case Net Metering Scenario Cash Flow 


\begin{tabular}{|c|c|c|c|c|c|c|c|c|c|c|}
\hline Operating Year & 1 & 2 & 3 & 4 & 5 & 6 & 7 & 8 & 9 & 10 \\
\hline \multicolumn{11}{|l|}{ Revenues $(\$ 000)$} \\
\hline Operating Revenues & 2,738 & 2,832 & 2,929 & 3,030 & 3,133 & 3,241 & 3,352 & 3,467 & 3,586 & 3,709 \\
\hline Other Income & 0 & 0 & 0 & 0 & 0 & 0 & 0 & 0 & 0 & 0 \\
\hline Total Revenues & 2,738 & 2,832 & 2,929 & 3,030 & 3,133 & 3,241 & 3,352 & 3,467 & 3,586 & 3,709 \\
\hline \multicolumn{11}{|l|}{ Expenses $(\$ 000)$} \\
\hline Power Supply & 1,650 & 1,707 & 1,765 & 1,826 & 1,888 & 1,953 & 2,020 & 2,089 & 2,161 & 2,235 \\
\hline O\&M & 300 & 312 & 325 & 338 & 351 & 366 & 380 & 396 & 412 & 428 \\
\hline Property Taxes & 0 & 0 & 0 & 0 & 0 & 0 & 0 & 0 & 0 & 0 \\
\hline Franchise Fee & 0 & 0 & 0 & 0 & 0 & 0 & 0 & 0 & 0 & 0 \\
\hline Total Expenses & 1,950 & 2,019 & 2,090 & 2,163 & 2,240 & 2,319 & 2,400 & 2,485 & 2,572 & 2,663 \\
\hline Net Operating Income (\$000) & 788 & 813 & 839 & 866 & 894 & 922 & 952 & 982 & 1,013 & 1,046 \\
\hline \multicolumn{11}{|l|}{ Debt Service $(\$ 000)$} \\
\hline Principle & 282 & 282 & 282 & 282 & 282 & 282 & 282 & 282 & 282 & 282 \\
\hline Interest & 664 & 642 & 619 & 597 & 574 & 552 & 529 & 507 & 484 & 462 \\
\hline Total Debt Service & 946 & 923 & 901 & 878 & 856 & 833 & 811 & 788 & 766 & 743 \\
\hline Debt Service Reserve Fund & 845 & 861 & 879 & 896 & 914 & 933 & 951 & 970 & 990 & 1,009 \\
\hline Debt Reserve Interest & 17 & 17 & 18 & 18 & 18 & 19 & 19 & 19 & 20 & 20 \\
\hline Capital Outlays (\$000) & 200 & 203 & 206 & 209 & 212 & 215 & 219 & 222 & 225 & 229 \\
\hline Funds Net DS & $(1,185)$ & $(296)$ & $(250)$ & $(203)$ & $(156)$ & $(108)$ & $(59)$ & $(9)$ & 42 & 94 \\
\hline \multicolumn{11}{|l|}{ Income Taxes } \\
\hline Utility Tax (City Ordinance) & 0 & 0 & 0 & 0 & 0 & 0 & 0 & 0 & 0 & 0 \\
\hline St. Tax/Other & 0 & 0 & 0 & 0 & 0 & 0 & 0 & 0 & 0 & 0 \\
\hline Total Income Taxes & 0 & 0 & 0 & 0 & 0 & 0 & 0 & 0 & 0 & 0 \\
\hline Net Available Funds & $(1,185)$ & $(296)$ & $(250)$ & $(203)$ & $(156)$ & $(108)$ & (59) & (9) & 42 & 94 \\
\hline Net Present Value - $10 \mathrm{Yr}$ & $(1,929)$ & & & & & & & & & \\
\hline Debt Service Coverage Ratio & 0.83 & 0.88 & 0.93 & 0.99 & 1.04 & 1.11 & 1.17 & 1.25 & 1.32 & 1.41 \\
\hline
\end{tabular}

Fig. C-2. Base Case Utility Scenario Cash Flow (No Generation) 
Viejas Tribal Government

Renewable Energy Development on Tribal

Lands of Viejas Study

Appendix D. Legal Analysis

Appendix D. Legal Analysis 


\section{Fredericks, Pelcygen \& Hestex, $\mathscr{L} L \mathscr{C}$}

THOMAS W. FREDERICKS ROBERT S. PELCYGER •

DANIEL W. HESTER

JOHN FREDERICKS III

ATTORNEYS AT LAW

CHRISTOPHER PLAZA 1075 SOUTH BOULDER ROAD SUITE 305

CHRISTOPHER B. LEAHY

CARLA J. HOKE

TARA L. ALLGOOD

NICCOLE L. SACCO

- ADMITTED ONLY IN CALIFORNIA

TOM W. ECHOHAWK (1952 - 1982)
(303) 673-9600

TELEFAX (303) 673-9155

TELEFAX (303) 673-9839

E-mail info@fphw.com

\section{MEMORANDUM}

TO: $\quad$ Tribal Council, Viejas Band of Kumeyaay Indians

FROM: $\quad$ Fredericks, Pelcyger \& Hester, LLC

DATE: June 23, 2005

RE:

LEGAL ISSUES IN THE FORMATION OF A TRIBAL UTILITY

\section{$\underline{\text { Introduction }}$}

The Viejas Band of Kumeyaay Indians conducted a study regarding the feasibility of constructing a renewable energy project (the "Project") on tribal lands. See Renewable Energy Development on Tribal Lands of Viejas Black \& Veatch (herein after "B\&V") Project Number 135650, May 2005. This memorandum will address various tribal, federal and state regulatory issues in forming a tribal utility.

\section{$\underline{\text { Statement of the Facts }}$}

The Viejas Band of Kumeyaay Indians ("Tribe") is a federally recognized tribe in San Diego County, California. The Viejas Reservation is comprised of approximately 1,600 acres of tribal trust lands, with another 15,000 acres that is shared in a joint-trust patent with the Barona Band of 
Mission Indians. ${ }^{1}$ The proposed project will be located within the 1,600 acre part of the Reservation. The Reservation's electrical needs are currently served by San Diego Gas \& Electric (SDG\&E). The Project is to be constructed on tribal land using one or more renewable energy options. Those options are wind, solar, bio-fuel, co-generation, and fuel cell technology. B\&V at TC-1, TC-2.

The feasibility study identified three different options for the Tribe:

1. Option \#1- Net Metering: Under this scenario, the Tribe would remain connected to SDG\&E. The energy generated by the renewable resource would be essentially credited towards the Tribe's energy bill.

2. Option \#2 - Tribal Utility Interactive with the Grid: Under this scenario, the Tribe would remain connected to SDG\&E but form its own separate tribal utility ("Viejas Utility"). Energy would be generated on the Reservation but the Viejas Utility would have an agreement with SDG\&E and/or other providers to wheel wholesale energy on or off the Reservation.

3. Option \#3 - Tribal Utility Independent of the Grid: Under this scenario, the Tribe would form its own separate utility, maintain its current connection with SDG\&E, but in essence become independent of the grid by the constructing its own complete energy management facilities on the Reservation, and/or purchasing the existing

${ }^{1}$ See Viejas Band of Kumeyaay Indians website, "Viejas Past and Present: History"

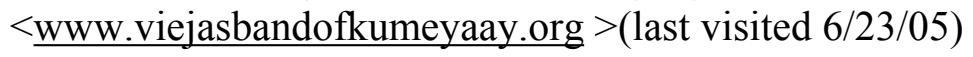


distribution system, which is presumably owned by SDG\&E. The Tribe may or may not choose to buy or sell power from or to SDG\&E or other utilities.

\section{$\underline{\text { Legal Analysis }}$}

\section{Questions Presented}

- Does the Tribe have the authority to charter and operate a tribally owned utility on the Reservation? If so, what steps does the Tribe need to take to create a tribal utility?

- Will the Viejas Utility be subject to Federal regulation under the Federal Power Act, 16 U.S.C. $\S 824$ et seq.?

- Will the Viejas Utility be subject to the Federal Public Utility Regulatory Act (PURPA) 16 U.S.C. $\S 2601$ et seq.?

- What other federal laws could apply to the Project?

- Will the Viejas Utility be subject to California State Utility Regulation?

As set forth below, it is our legal opinion that the Tribe has sovereign authority to charter and operate a tribal utility on Reservation trust land. Moreover, the Viejas Tribal Utility would be subject to Federal PURPA Regulation but no other Federal or State regulation under the above statutes, if they follow the steps outlined in this memo.

\section{Tribal Authority to Own and Operate an Electric Utility.}

It is our opinion that the Tribe has inherent sovereign authority to charter, operate and regulate an electric utility for purposes of providing service to on-Reservation customers located on tribal lands. After examining the principles of federal Indian law on which we base our opinion, this section will then discuss the steps which may be taken by the Tribe to exercise and implement its authority to establish an on-Reservation electric utility. 


\section{A. The Tribe's Inherent Sovereign Authority.}

Indian tribes have long been recognized as distinct, independent political communities with the power of self-government over both their members and their territory. Worcester v. Georgia, 31 U.S. (6 Pet.) 515 (1831); California v. Cabazon Band of Indians, 480 U.S. 244 (1987). Tribal sovereignty does not stem from any delegation of power by federal or state governments, but from an early acknowledgement by foreign nations coming to the New World that the various native Indian tribes were separate distinct political entities. Johnson v. McIntosh, 21 U.S. (8 Wheat) 543 (1823). The sovereignty of Indian tribes is therefore inherent, and predates this Tribe's existence. Santa Clara Pueblo v. Martinez, 436 U.S. 49, 55-56 (1978). Congress has long recognized the sovereignty of Indian tribes and federal Indian policy has been dominated by a firm congressional commitment to the promotion of "Indian self-government including [the] overriding goal of encouraging tribal self-sufficiency and economic development." New Mexico v. Mescalero Apache Tribe, 462 U.S. 324, 334-35 n. 17 (1983). Tribes today continue to possess all aspects of their sovereignty except that which has been expressly withdrawn by treaty or statute, or by implication as a necessary result of their so-called dependent status. United States v. Wheeler, 435 U.S. 313, 323 (1978).

The Tribe's governmental authority over its own members is well-established. McClanahan v. Arizona State Tax Comm'n, 411 U.S. 164, 167-71 (1973). However, tribal governmental authority over non-members within the Reservation has been severely diminished by the United States Supreme Court. The civil jurisdiction to regulate non-Indians in modern times was addressed in Montana v. United States, 450 U.S. 544 (1981). In Montana, the Supreme Court resolved two disputes between the state of Montana and the Crow Tribe. The first dispute involved the ownership of the bed and banks of the Bighorn River within the Crow Indian Reservation. The second dispute 
addressed by the Supreme Court was the Crow Tribe's right to regulate hunting and fishing by nonmembers within the Reservation on non-member owned land that was held in fee. The Crow Tribe had proposed to regulate hunting and fishing by non-members on their fee lands within the Crow Reservation relying on the Crow Tribe's treaty rights and the Tribe's inherent sovereignty. The Supreme Court held that tribal regulatory power over non-member hunting and fishing on fee land within the Reservation was inconsistent with the Crow Tribe's dependent status. Montana v. U.S., 450 U.S. at 551 (citation omitted). The Supreme Court in so holding fashioned a general rule that the "exercise of tribal power beyond what is necessary to protect tribal government or to control internal relations is inconsistent with the dependent status of the tribes, and so cannot survive without express congressional delegation." Id. at 566-67. Although Montana involved a Tribe's attempt to regulate non-members on land owned in fee by non-members, the Court recently expanded Montana to limit tribal authority over non-members on tribal trust land as well. Nevada v.

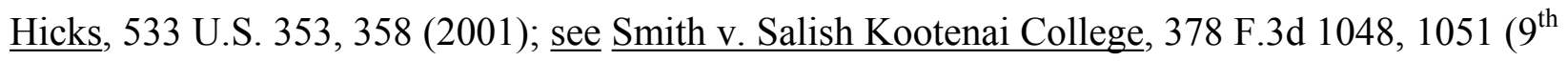
Cir. 2004) (explaining Montana and $\underline{\text { Hicks) }}$. The effect of the Supreme Court rulings reversed the longstanding traditional presumption that Indian tribes retain power until Congress takes it away. Instead, after Montana, the presumption is that tribes do not retain power over non-members within the Reservation boundaries.

The Supreme Court in articulating the new presumption of no civil jurisdiction over nonmembers granted two exceptions to the Court's rule. First, "a tribe may regulate, through taxation, licensing, or other means, the activities of non-members who enter consensual relationships with the tribe or its members, through commercial dealings, contracts, leases or other arrangements." Montana, 450 U.S. at 465. Second, tribes "retain inherent power to exercise civil authority over the conduct of non-Indians on fee lands within [the tribe's] Reservation when that conduct threatens or 
has some direct effect on the political integrity, the economic security, or the health and welfare of the tribe. $I d$. at 566. As a result of the Montana decision, absent a recognition of power from Congress, the Tribe's authority to regulate non-Indians within the Reservation depends on whether one of the aforementioned exceptions is applicable.

Tribal authority over non-members within the Reservation was addressed in three other Supreme Court cases, Brendale v. Confederated Tribes and Bands of Yakima Indian Reservation, 492 U.S. 408 (1989), South Dakota v. Bourland, 508 U.S. 679 (1993), and Strate v. A-1 Contractors, et al., 520 U.S. 438 (1997). Brendale involved tribal authority to regulate zoning on non-Indian fee land within the Yakama Indian Reservation. The Supreme Court in Brendale rendered a 4 to 3 to 2 plurality decision with the deciding opinion holding that the Tribe had no authority to zone in the open area of the Reservation (an area where a significant portion of land was owned by nonmembers in fee status), but could zone in the closed area (an area containing mostly Indian trust land) since it had retained its authority to determine the closed area's character. The distinction between open and closed areas was based on a theory of exclusion: the Tribe had lost its inherent authority to zone non-member land in the open area because it had not excluded non-Indians from the area. Because the Tribe had not excluded non-Indians, it lost the right to determine the essential character of the land (i.e., to zone). Congressional delegation or divestment of power was not an issue, according to the opinion, because Congress had not spoken on zoning. Brendale, 492 U.S. at 433 (Stevens, J., concurring).

The next case that addressed tribal authority to regulate non-Indians within the Reservation was South Dakota v. Bourland, 508 U.S. 679 (1993). In Bourland, the Supreme Court held that the Cheyenne River Sioux Tribe did not have authority to regulate non-Indian hunting and fishing on land and overlying waters located within the Tribe's Reservation but acquired by the United States 
for the operation of the Oahe Dam and Reservoir. The Court relied on the Montana analysis and determined that when the United States acquired the land from the Cheyenne River Sioux Tribe for flood control purposes, the Tribe lost its right to exclude non-members from the acquired land. Consequently, the Supreme Court determined that the land taken by the United States for the operation of the Oahe Dam and Reservoir was treated as non-Indian fee land and therefore the Tribe could not regulate non-Indian hunting and fishing on said lands. As stated above, after Nevada v. $\underline{\text { Hicks, }}$ land status is no longer relevant. The limitation on tribal authority over non-members applies to activity on trust land as well as fee land.

The other Supreme Court case that addressed a tribe's authority to regulate non-Indians involved Strate v. A-1 Contractors, et al., 520 U.S. 438 (1997). The Supreme Court in $\underline{\text { Strate again }}$ relied on the Montana analysis to find that the tribal court of the Fort Berthold Indian Reservation was without authority to adjudicate a civil dispute between two non-Indians who had an accident within a state highway right-of-way within the Fort Berthold Indian Reservation.

Collectively, the foregoing Supreme Court decisions have severely eroded the Tribe's ability to regulate non-members on fee lands. Today, it seems that Indian tribes have little or no authority over non-Indians on the Reservation "if the nonmember has a right to be where he is." County of Lewis v. Allen, 141 F.3d 1385, 1394 (9th Cir. 1998) (Boochever, J., concurring).

Although it is arguable whether the Tribe would be able to assert civil jurisdiction over nontribal members under the second Montana exception discussed above, the Tribe may be able to meet the first Montana exception by entering into consensual contracts to serve any non-tribal members on the Reservation. The tribal utility will need to draft its agreements with the non-members in such a way as to come within the first exception of the Supreme Court's decision in Montana. Moreover, Indian tribes arguably retain the authority to regulate electric utility services occurring on trust land 
regardless of whether the provider or user of such service is a tribal member or a non-tribal member. Regulation of utilities involves an important exercise of police powers. See Ark. Elec. Coop. v. Ark. Public Serv. Comm'n., 461 U.S. 375, 377 (1983). As independent sovereigns, Indian tribes possess police power over their territories similar to those possessed by states. Wauneka v. Campbell, 22 Ariz. App. 287, 290, 526 P.2d 1085 (1974). It may be asserted that the Tribe's power to regulate utilities is an essential attribute of tribal sovereignty as it is a necessary instrument of self-government and territorial management. Tribal authority to regulate electric power distribution is no different from its unquestionable authority to impose building, health and safety regulations on members and non-members alike within the boundaries of the Reservation. Cardin v. De La Cruz, 671 F.2d 363 (9th Cir. 1982).

We conclude that pursuant to its inherent sovereignty, the Tribe is empowered to charter, operate and regulate an electric utility authority to be wholly owned by the Tribe, and to provide service to customers within the Reservation, as provided in the discussions supra. We recommend that the Tribe implement a comprehensive utility regulatory scheme on the Reservation which will tip the scales sharply in favor of tribal jurisdiction and minimize any interest in on-Reservation jurisdiction the state may attempt to assert. The Tribe will have regulatory jurisdiction over nonmembers if the tribal utility enters into consensual agreements with the non-members to provide electric utility service.

\section{B. Organization of the Tribe's Electric Utility.}

Initially, the Tribe's governing body should adopt a Reservation Public Utilities Ordinance. The ordinance should, among other things, establish a Tribal Public Utilities Commission as the regulatory body charged with administering and enforcing the ordinance within the jurisdiction of the Tribe. It could also establish, or prescribe procedures for establishing, rates and charges by on- 
Reservation utilities including, but not limited to, the tribal electric utility. Standards covering the construction, location and specification of utility facilities should also be prescribed. The ordinance could also set forth the conditions pursuant to which exclusive certificates of convenience and necessity would be issued to tribal utilities to serve on-Reservation. ${ }^{2}$

In addition to promulgating the ordinance, the tribal governing body could issue a charter to create and empower the electric utility. The charter would be roughly analogous to articles of incorporation for a state-organized corporation and would be issued pursuant to the powers vested in the Tribe's governing body. The charter would establish the electric utility as an authority or agency of the Tribe, thereby affording it the Tribe's sovereign immunity and other benefits deriving from tribal government status. The charter could also empower the electric utility to promulgate bylaws establishing internal operational procedures.

After the electric utility is chartered by the Tribe, it may then proceed with organizational and operational matters. It is recommended that the electric utility hire a general manager that is experienced in the electric utility industry to act as manager and perform the necessary tasks of developing, constructing and negotiating the purchase of existing utility lines, poles, substation meters and other equipment to get the utility operational. The manager would be responsible for staffing the utility, proposing a rate structure consistent with the Tribe's ordinance, establishing a billing system, arranging for funding, entering into facility construction contracts, obtaining necessary government approvals, securing a source of power and other matters necessary for startup.

\footnotetext{
${ }^{2}$ In Segundo v. City of Rancho Mirage, 813 F.2d 1387, 1393 ( $9^{\text {th }}$ Cir. 1987), the Ninth Circuit, in holding the cities' rent control ordinances unlawful on the Reservation, found significant the fact that application of the cities' ordinances would preclude enforcement of a conflicting ordinance enacted by the Tribe and effectively nullify the Tribe's authority to regulate the use of its lands.
} 
Taking over SDG\&E's customer base on the Reservation will be difficult logistically, but not impossible. The easiest way to assume SDG\&E's functions would be to purchase its on-Reservation distribution system at a negotiated price. In many cases, utility providers on trust land fail to obtain proper easements for the construction of an operation of their distribution lines, as required by federal law.

In such cases, the Tribe has a cause of action for trespass damages, which the Tribe can then use to negotiate a mutually acceptable takeover of the existing facilities, with any damages that the Tribe can claim to be credited against the agreed value of purchase price of the facilities. Obviously, if the Tribe and the tribal utility authority can put themselves in a position to acquire the existing facilities, that will greatly reduce their start-up costs and do away with having to build a new transmission and distribution system.

A more expensive option is to build an entirely new system, which may be cost prohibitive depending on existing and potential future customer load on the Reservation. We recommend that the Tribe enter into negotiations to purchase SDG\&E's existing system.

\section{Federal Regulatory Interests}

\section{A. The Tribe is Not Subject to FERC Regulatory Control Under 16 U.S.C. ' 824 et seq.}

The federal government regulates the generation and transmission of electric power under the Federal Power Act, 16 U.S.C. $\S \S 824-824 m$, through the Federal Energy Regulatory Commission (FERC). We opine that a wholly owned tribal utility would be exempt from FERC regulatory control pursuant to 16 U.S.C. $\S 824$ (f) which provides, in regards to certain government owned utilities:

(f)United States, State, political subdivision of a State, or agency or instrumentality thereof exempt. No provision in this Part [16 U.S.C. ' ' 824 et seq.] shall apply to, or be deemed to include, the 
United States, a State or any political subdivision of a State, or any agency, authority, or instrumentality of any one or more of the foregoing, or any corporation which is wholly owned, directly or indirectly, by any one or more of the foregoing, or any officer, agent, or employee of any of the foregoing acting as such in the course of his official duty, unless such provision makes specific reference thereto.

FERC has ruled that a wholly owned tribal utility qualifies as an exempt government-owned utility under the above statute. Sovereign Power Inc. v. FERC, FERC Dkt. No. ER 98-2995-000 (July 13, 1998). In Sovereign Power, a tribal corporation, wholly owned by the Spokane Tribe of Indians, wished to sell wholesale power and asked that FERC disclaim jurisdiction over it, which the Commission did. The Commission applied a test based on the instrumentality definition in $\underline{\text { City of }}$ Paris, KY v. FPC, 399 F.2d 983 (D.C. Cir. 1968) that looks to whether the utility "performs an inherent government function” Id. at 986. The Commission in Sovereign Power ruled that:

The Spokane tribe performs inherent government functions and the funds generated by Sovereign will be used by the tribe on the behalf of the government and in performance of government functions. This money collected by Sovereign will also mean that the tribe will need less funding from the federal government and this generally promotes the goal of encouraging tribal self-determination and economic independence.

Id. at 2-3.

The Commission stated that the Spokane Tribe is "subject to extensive federal oversight," including the protection of trust land and various laws requiring federal approval of proposed tribal transactions. Id. at 3. FERC further relied on the "long-standing principle of statutory construction that $>$ Statutes are to be liberally construed in favor of the Indians, with ambiguous provisions

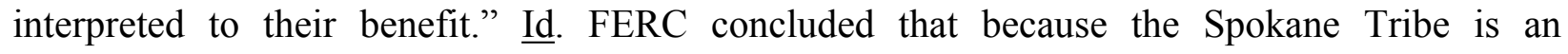
instrumentality of the federal government, the Tribe's wholly owned Power Corporation was not a "public utility" for the purposes of FERC's jurisdiction under the FPA. In determining that the City 
of Paris test applied, FERC considered and rejected opposing cases which held that tribes are not instrumentalities of the federal government. Id. at 3 (citing United States v. Wheeler, 435 U.S. 313 (1978) and Smart v. State Farm Insurance Co., 868 F.2d 929 ( $7^{\text {th }}$ Cir. 1989). In footnote 1 of Sovereign Power, FERC stated that it was issuing a separate notice informing Chickasaw Nation Industries (a tribal utility) that FERC disclaimed jurisdiction over its application. FERC thus signaled its intent that the Sovereign Power ruling was to be uniformly applied in Indian Country. To conclude, the Viejas Utility would be performing an inherent government function by generating power and funds on behalf of the Viejas government. Thus they would not be a "public utility".

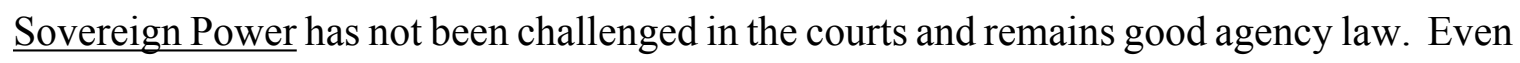
if a FERC determination on the Viejas utility were challenged, the federal courts "give great deference" to FERC decisions on review. Northeast Utilities Co v. FERC, 993 F.2d 937, 943 (1993). AQuestions involving an interpretation of the FPA involve a de novo determination by the court of Congressional intent; if that intent is ambiguous, FERC's conclusion will only be rejected if it is unreasonable." Id. at 944 . Because Congress did not clearly state its intent as to whether or not tribes are exempt under 16 U.S.C. ' 824(f), it is our legal opinion that courts would affirm FERC's determination of the issue.

The conclusion that a Viejas utility is exempt under16 U.S.C. § 824(f) is consistent with an opinion by the Solicitor of the Department of the Interior, which found that Indian tribes are qualified, "like States and political subdivisions," to participate under the Small Business Reclamation Act of 1956, 25 U.S.C. ' 422a-422k. ${ }^{3}$

\footnotetext{
${ }^{3}$ See Solicitor's Opinion, No. G-65-1097.3 (Dept. of the Interior August 13, 1965) (cited in Indian Tribes as Preference Customers Under the Reclamation Project Act of 1939, Solicitor's Opinion, No. m-366771 (Dept. of the Interior July 25 1967)).
} 
Based upon the above legal precedent established by the above-cited authorities, we conclude that FERC would not have jurisdiction over the Viejas Utility as long as the Utility uses the net revenues generated by the Utility on behalf of the government and to fund governmental functions or services.

\section{B. The Tribe Would be Subject to Federal Regulation under the Public Utility Regulatory Act (PURPA), 16 U.S.C. $§ § 2601$ et seq.}

PURPA was enacted by Congress in 1978. Its purpose is "to promote the development of new generating facilities and to conserve the use of fossil fuels." New York v. FERC, 535 U.S. 1, 9 (2002). Through this Act Congress encourages renewable energy projects such as the Viejas Utility by securing a market for their power and establishing fair prices for said power. To qualify under the act is a two step process, the first being as a "small power production facility" and the second as a "qualifying small power production facility". The Viejas Utility would qualify as a "small power production facility" under 16 U.S.C. § 796(17)(A), which provides that:

[a small power production facility] is an eligible solar, wind, waste, or geothermal facility, or a facility which-

(i) produces electric energy solely by the use, as a primary energy source, of biomass, waste, renewable resources, geothermal resources or any combination thereof; and

(ii) has a power production capacity which, together with any other facilities located at the same site (as determined by the Commission), is no greater than 80 megawatts.

The Viejas Utility would then be eligible as a "qualifying small power production facility" under 16 U.S.C. $\S 796(17)(e)$. This is because it would meet the requirements of a "small power production facility" and though it would be engaged in selling the energy it produces the energy sold would be generated solely from the same "small power production facility" The statute provides:

.... a small power production facility-

(i) which the Commission determines, by rule, meets such requirements (including requirements respecting fuel use, fuel 
efficiency, and reliability) as the Commission may, by rule, prescribe; and

(ii) which is owned by a person not primarily engaged in the generation or sale of electric power (other than electric power solely from cogeneration or small power production facilities);

16 U.S.C. $\S 796(17)(\mathrm{e})$.

Regulation under PURPA could have beneficial effects for the Tribe. If the Tribe chooses to wheel or sell power outside of the Reservation as suggested in the feasibility study, see B\&V, at 7-2, then under FERC's jurisdiction, SDG\&E and other utilities would be required to purchase the energy generated by the Viejas Utility under 16 U.S.C. $\$ 824 a-3(a)(2)$. See also FERC v. Mississippi, 456 U.S. 742 (1982) "In order to overcome...these perceived problems, $§ 210(a)[\S$ 824a-3(a)(2)] directs FERC...to promulgate...rules requiring utilities to offer to sell electricity to, and purchase electricity from, qualifying cogeneration and small power production facilities.” $\underline{\text { Id. }}$ at 751 (all emphases added). In addition, the utilities must purchase at a price that is "just and reasonable" and must Anot discriminate against alternate energy producers (AEPs).” 16 U.S.C. $§ ~ 824 a-3(b)$. In conclusion the Viejas Utility would be subject to PURPA jurisdiction and thus would be privy to its benefits.

\section{Other Federal Laws and Regulations}

Depending on what type of project Viejas chooses, the following laws, regulations, and regulatory authorities may apply.

1. Leasing Lands: If the lands on which a project is situated are leased, the lease needs to comply with 25 U.S.C. ' 415(a) and 25 C.F.R. Part 162. 25 C.F.R. Part 162 requires compliance with NEPA, 42 U.S.C. ' ' 4321 to 4370d. NEPA requires submission of an environmental impact statement (EIS) for every major federal action significantly affecting the quality of the human environment. Leasing lands constitute a major federal 
action. Davis v. Morton, 469 F.2d 593 (10 ${ }^{\text {th }}$ Cir. 1972). An EIS includes an analysis of environmental impact, proposed adverse effects, alternatives, maintenance and enhancement of long-term productivity, irreversible commitments of resources, and other information. 40 C.F.R. ' 1507(a)(1). However, depending on what renewable plan is adopted, an environmental assessment (EA) may be used to determine whether an EIS is necessary based on the proposed action. 40 C.F.R. ' 1508.9. If an EIS is not necessary, then a finding of no significant impact (FONSI) will be issued. 40 C.F.R. ' 1508.9.

2. Clean Air Act (CAA), 42 U.S.C.S. ' 7410(a): The EPA has primary regulatory authority over the on-Reservation air space under the CAA. 42 U.S.C. ' 7410(c). A tribe may assume authority under Section 7601(d)(1)(A). EPA has primary regulatory jurisdiction for compliance with the CAA.

The Tribe will need to get a PSD (prevention from significant deterioration) permit from EPA Region IX for compliance with 42 U.S.C. $\S 7477$ of the CAA and pursuant to 40 C.F.R. Part 52. A PSD permit usually takes 6-10 months, so in certain instances there may be a need for the Tribe to request an expedited review. Under expedited review, a tribe would enter into an agreement with EPA through an Administrative Order on Consent and would consent to mitigate other air impacts in future projects as well as comply with PSD permitting requirements in exchange for the EPA allowing a project to operate in the interim. It is not clear whether Region IX (EPA California) has experience with the expedited process. Within 12 months of operation, a Title $\mathrm{V}$ permit application will need to be completed and submitted to EPA Region IX. 
The State of California or a regional entity does not have air quality jurisdiction over Reservations in California. Many California tribes have obtained air grants and tribes are managing their own air quality programs. ${ }^{4}$

While there may be some technical assistance provided by South Coast Regional Air Quality Management Authority, the technical assistance is minimal (if any) and the Regional Authority should be well aware that tribes have jurisdiction over the Reservation.

3. Clean Water Act (CWA) 33 U.S.C. ' ' 1251-1387: Tribes may assume authority of a project under the CWA. 33 U.S.C. ' 1377 . For purposes of a proposed project, the relevant provision of the CWA is 33 U.S.C. $§ 1342$, National Pollutant Discharge Elimination System (NPDES). If there is any discharge, it may be enough to warrant an NPDES permit. This will need to be verified by EPA.

4. Safe Drinking Water Act (SDWA) 42 U.S.C. ' ' 300f et seq.: Tribes may assume authority of a project under the SDWA. 42 U.S.C. ' $300 j-11$. The SDWA may be applicable if a project requires drilling for a well, injecting fluids or other materials into the ground, or creates underground storage for materials. See 40 C.F.R. Part 144.

\section{Resource Conservation and Recovery Act (RCRA) 42 U.S.C. ' ' 6901 et}

seq.: The RCRA regulates the disposal of solid waste, including but not limited to management of hazardous solid wastes, non-hazardous solid wastes and regulation of underground storage tanks. See 40 C.F.R. Part 260. However, the EPA may not have the ability to review and/or approve solid waste management plans of tribes and/or tribal entities. See Backcountry Against Dumps v. EPA, 100 F.3d 147 (D.C. Ct. App. 1996). RCRA allows for assistance agreements with Indian tribes for hazardous waste management

\footnotetext{
${ }^{4}$ See the EPA website, "Tribal Air: Region 9 Information" $<$ http://www.epa.gov/air/tribal/region/r9prgmhi.html $>$
} 
programs and underground storage tank programs. 42 U.S.C. ' 6908a. More information about solid waste produced by the Project is needed to determine whether RCRA compliance and/or an assistance agreement will be required.

6. Superfund (CERCLA) 42 U.S.C. ' ' 9601-9675: CERCLA applies to hazardous substance releases, liability and compensation for such releases. CERCLA should not be an issue to Viejas unless there is or has been an unlawful release at the site.

7. Endangered Species Act (ESA) 16 U.S.C. ' ' 1531-43: Specifically, Section 9 (16 U.S.C. $§ 1538(a)$ ) of the ESA requires that "any person" is prohibited from taking any action that will impact listed species or result in the destruction or adverse modification of designated critical habitat. This has been interpreted to include Indian tribes. The Tribe's natural resources department should make a preliminary determination about whether any species (listed or proposed) may be present on the site or impacted by a project. Once the preliminary determination has been made, a request needs to be made to the Secretary for her determination. 16 U.S.C. '1536(c). If there is a species at risk, a biological assessment needs to be conducted. $\underline{\text { Id. }}$

8. National Historic Preservation Act (NHPA) 16 U.S.C. ' ' 470-470w-6: If the Project site or a building on the site has been designated as protected under the NHPA, the Project must comply with NHPA requirements. 16 U.S.C.S. ' 470 f.

9. Occupational Safety and Health Act (OSHA) 29 U.S.C. ' 667 et seq.: The Occupational Safety and Health Administration of the Department of Labor administers OSHA. However, state or tribal OSHA programs may assume responsibility for developing their own occupational safety and health standards by submitting and obtaining Federal approval of a plan. Id. and 29 C.F.R. Part 1952. However Federal OSHA retains 
enforcement authority over tribal workplaces. 29 C.F.R. ' 1952.122 . Federal OSHA does not have a construction certification process. However, construction undertaken by the Tribe or other entity may need to comply with federal construction regulations as promulgated under 29 C.F.R. Part 1926. Part 1926 also incorporates some requirements outlined in Part 1910, including requirements to be met during the generation, transmission and distribution

of electrical power. Also, the construction project will need to have a safety and health program, a hazard communications program (29 C.F.R. ' 1910.1200) and other programs as required by OSHA.

\section{Native American Graves Protection and Repatriation Act (NAGPRA), 25}

U.S.C. ' 3001 et seq.: NAGPRA applies to objects excavated or discovered on Federal or tribal lands. Should any "cultural item", 25 U.S.C. $§ 3001(3)$ be found on the site, the handling of such item must be consistent with NAGPRA and the item must be turned over to the appropriate tribe.

\section{Archaeological Resources Protection Act (ARPA), 16 U.S.C. ' 470aa et} seq.: If a project is located on "Indian lands," and requires excavation or removal, it must comply with ARPA. 16 U.S.C. ' 470ii(c). If excavation of, or removal within, the site is required, a permit must be obtained. 16 U.S.C. ' $470 \mathrm{cc}$.

12. Acquisition of Rights of Way: Under the General Right-of-Way Act of 1948, tribal grants of rights of way are subject to Secretarial and tribal official approval. 25 U.S.C. ' 323-328. Applicable regulations are found at 25 C.F.R. Part 169. If future rightsof-way are needed from the Tribe, the granting of a right-of-way to an entity other than the Tribe will require compliance with the Right-of-Way Act. 


\section{Federal Tax Implications.}

The analysis thus far has, per the feasibility study, relied on the fact that the Tribe wishes to form a non-profit tribal utility. The Tribe may also wish to form a "for profit" corporation. There are tax implications for the latter.

The Tribe may choose to incorporate a tribal utility under tribal law if authorized by the Tribal Constitution. The Tribe may also choose to incorporate a tribal utility under Section 17 of the Indian Reorganization Act (IRA) of 1934, 25 U.S.C. $§ 477$. Incorporation under Section 17 exempts the enterprise from federal income tax, regardless of where the business is located. Finally, the Tribe could also choose to incorporate a utility under California state law. However, incorporation under state law will most likely subject the utility to federal income tax.

\section{State Regulatory Authority.}

Traditionally, Indian Tribes are recognized as distinct, independent political communities, with inherent sovereign powers of self-government over both their members and territory. Worcester v. Georgia, 31 U.S. (6 Pet.) 515 (1821). Because of their sovereign status, tribes, as well as their Reservation lands, have enjoyed "a historic immunity from state and local control." Mescalero Apache Tribe v. Jones, 411 U.S. 145, 152 (1973). Generally, state laws are not applicable to the activities of the Tribe or its members on the Reservation unless Congress has expressly provided that state law applies. Worcester, 31 U.S. at 560-61; see, also Williams v. Lee, 358 U.S. 217, 221 (1959); McClanahan v. Arizona State Tax Comm’n, 411 U.S. 164, 170-71 (1973).

California is a Public Law 83-280 (P.L. 280) state. P.L. 280 granted California jurisdiction over criminal and certain civil matters involving Indians as a party on Indian lands. The grant of civil jurisdiction is codified in 28 U.S.C. $\S 1360$ (a). 
P.L. 280 makes a distinction between criminal laws that prohibit conduct and civil laws which regulate conduct. See California v. Cabazon Band of Mission Indians, 480 U.S. 202 (1987). In Cabazon, the Court held that California could not enforce the state's gaming laws in Indian country. The Court held that a state could prohibit conduct under criminal law but could not regulate conduct under civil law against an Indian in Indian country.

This decision was in line with and further strengthened Supreme Court precedent. The Supreme Court had previously held that P.L. 280 did not grant a state county the authority to tax an Indian living on Indian trust land in Bryan v. Itasca County, 426 U.S. 373 (1976). In analyzing the legislative history of P.L. 280, the Bryan court explained:

This construction finds support in the consistent and uncontradicted references in the legislative history to $>$ permitting $=>$ State courts to adjudicate civil controversies $=$ arising on Indian Reservations, H.R.Rep. No. 848, pp. 5, 6 (emphasis added), and the absence of anything remotely resembling an intention to confer general state civil regulatory control over Indian Reservations.

Id.at 384 .

Federal statutes which provide for and operate in conjunction with tribal treaties and regulatory schemes may also preempt state authority. The test for preemption in the context of Indian law is a balancing test. Generally, state jurisdiction is preempted by federal law if it interferes with or is incompatible with federal and tribal interests as reflected in federal law, "unless the state interests at stake are sufficient to justify the assertion of state authority." New Mexico v. Mescalero Apache Tribe, 462 U.S. 324, 334 (1983), citing White Mountain Apache Tribe v. Bracker, 448 U.S. 136, 145 (1980). Courts assess the relative interests in light of the tribe's treaty rights, the tribe's inherent sovereignty, and Congress' overriding goal of encouraging "tribal selfsufficiency and economic development.” Mescalero Apache, 462 U.S. at 335, citing Bracker, 462 U.S. at 143 . 
Our current understanding is that the Viejas Utility will only serve tribal members on the Reservation. This scenario comports favorably with this balancing test first articulated in Bracker:

When on-Reservation conduct involving only Indians is at issue, state law is generally inapplicable, for the state's regulatory interest is likely to be minimal and the federal interest in encouraging tribal self-government is at its strongest.

Bracker, 448 U.S. at 144-45.

The ability of a state to regulate a tribal entity is further limited when a tribal government, with the support of the federal government, has adopted a comprehensive regulatory policy. See Mescalero Apache Tribe, 462 U.S. at 341. The Viejas Utility will require drafting of a tribal utility code, as well as rules and regulations necessary for the operation and maintenance of the utility. A sample code has been included with this memo.

Based on the above authorities, we opine that the Viejas Utility will not be subject to state regulation provided that the Tribe adopts a comprehensive regulatory plan and that the energy is distributed solely on the Reservation.

\section{$\underline{\text { Conclusion }}$}

Based on the above analysis, our opinion is as follows:

1. That the Viejas Tribe has the authority to charter and operate a tribal utility pursuant to its inherent sovereignty;

2. That FERC will not have jurisdiction over the Viejas Tribal Utility if the utility is wholly owned by the Tribe;

3. That PURPA will have jurisdiction over the Viejas Tribal Utility. If the Viejas Utility chooses to sell power back across the Reservation border PURPA would serve a beneficial effect in assisting the Utility in selling their power and receiving an equitable price for it; and 
4. That the State of California will not have jurisdiction to regulate the activities of the Utility if it comports with the requirements set forth in Conclusion 2, above.

H:IVIEJAS \Utility Memo2(No FERC) FINAL.doc 


\section{CHARTER OF THE AHA MACAV POWER SERVICES}

\section{ARTICLE I}

Name

The Fort Mojave Indian Tribe, acting through the Council of the Fort Mojave Tribe and the Fort Mojave Constitution and Bylaws, hereby authorizes this Charter under Article IV of the Constitution of the Fort Mojave Tribe as amended. The name of this tribally chartered authority is the Aha Macav Power Services (AMPS). The Fort Mojave Tribe confers on AMPS all of the Tribe's rights, privileges and immunities as if it engaged in the activities undertaken by AMPS, including, but not limited to, the Tribe's rights of eminent domain, taxation and sovereign immunity.

\section{ARTICLE II}

Duration

The period of existence of AMPS shall be perpetual, except that AMPS may have this charter amended or restated or AMPS may be dissolved in accordance with the Fort Mojave Tribal Constitution, as amended.

\section{ARTICLE III}

Purposes and Powers

A. General. The purposes for which AMPS is organized are to provide electric power to all users of such power within the Fort Mojave Indian Reservation and any other utility projects which would benefit the Tribe and that are approved by the Fort Mojave Tribal Council. The Fort Mojave Tribal Council hereby finds and declares that the creation of AMPS is necessary and desirable in order to promote the development of the Tribe's resources, to promote the prudent economic vitality of the Reservation and surrounding communities, to protect the health and welfare of tribal members and to provide employment and training opportunities for tribal members.

B. Enumerated Purposes. The purposes for which AMPS is organized are as follows:

1. To develop, operate and manage the provision of electric powers to all users of electricity within and/or on the Fort Mojave Indian Reservation or owned by AMPS unless the Fort Mojave Tribal Council specifically excludes a specific electricity user from AMPS control.

2. To develop, manage and control all other utilities operated within the Fort Mojave Indian Reservation when so requested by resolution or ordinance of the Fort Mojave Tribal Council.

3. To provide training and employment opportunities for members of the Tribe in the construction, management and operation of providing electric power to the users of electricity within the Fort Mojave Indian Reservation.

4. To facilitate economic development on the Reservation and in surrounding communities. Case Study: xxv NEOS Corporation Tohono O'odham Utility Authority

5. To enhance and protect the health and welfare of tribal members and the electric utility customers of AMPS.

6. To manage all electric utility enterprises owned or operated by AMPS in a prudent, efficient and economic manner in accordance with Tribal law.

C. Ancillary. To do everything necessary, proper, advisable or convenient for the accomplishment of the purposes hereinabove set forth, and do all things incidental thereto or connected therewith, which are not forbidden by law.

D. Enumerated Powers. AMPS shall have the following enumerated powers:

1. To sue and be sued in courts of competent jurisdiction.

2. To enter into contracts and agreements affecting the affairs of AMPS's service area and to accept all funds resulting therefrom.

3. To contract with private persons, associations, or corporations for the provision of any service within or without its boundaries and to accept all funds and obligations resulting therefrom. 
4. To borrow money and incur indebtedness and other obligations and evidence the same by certificates, notes or debentures and issue general obligation or revenue bonds, or any combinations thereof.

5. To refund any bonded or other indebtedness or special obligations of AMPS without an election.

6. To acquire, dispose of and encumber real or personal property, including, without limitation, rights and interests in property, including leases and easements necessary to accomplish the purposes of AMPS.

7. To acquire, construct, equip, operate and maintain facilities to accomplish the purposes of AMPS.

8. To manage, control and supervise all the business affairs and properties of AMPS.

9. To adopt, by resolution, rules and regulations consistent with federal, state and tribal law which are necessary, appropriate or incidental to any authorized services provided by AMPS.

10. To delegate the management of the day-to-day operation of AMPS to others, and in exercising its authority hereunder, may rely on its officers and other experts. AMPS shall establish policies and retain responsibility for the ultimate direction and affairs of AMPS but may give usual and essential latitude to AMPS Manager and his delegated employees.

11. To fix and collect taxes, rates, fees, tolls and other service charges pertaining to the services of AMPS, including, without limitation, minimum charges and charges for availability of the facilities or services relating thereto.

Case Study: xxvi NEOS Corporation Tohono O'odham Utility Authority

12. To construct, establish, and maintain works and facilities; (a) in, across, or along any

easement dedicated to a public use, or any public street, road or highway; (b) in, upon, or over

any vacant public lands; and (c) in, across, or along any stream or water course.

13. To plan for the development within the service area served by AMPS including, but not limited to, review of all comprehensive plans of tribal government located within AMPS's service area, and review of all capital construction of other federally funded projects proposed by any governmental entity within the boundaries of AMPS's service area for which review is required by federal, state or tribal law.

14. To require all commercial and residential units within the Reservation to connect to the electric service provided that said unit is within AMPS's designated service area.

15. To have and exercise all powers necessary, convenient or incidental to the express powers identified above.

E. Exercise of AMPS's Powers. AMPS shall exercise its authorized powers in good faith and in a manner which is believes to be in the best interests of the Fort Mojave Indian Tribe and the interests of those within AMPS's service area.

F. Interpretation. The purpose specified herein shall be construed as both purposes and powers.

\section{ARTICLE IV}

Ownership

To enable AMPS to carry out its purposes, the Fort Mojave Tribal Council may, from time to time at the request of the Board of Directors of AMPS, vest AMPS with the power to exercise all of the Fort Mojave Tribe's powers with respect to designated tribal properties, both, real and personal, in accordance with the purposes and powers under Article III of this Charter. Such properties transferred to AMPS shall not be revocable by the Fort Mojave Tribal Council during the period AMPS is authorized to exercise control and possession of the transferred properties.

\section{ARTICLE VI}

Assets

Subject to such contractual rights of others, including the Fort Mojave Tribe, AMPS shall have as its assets, and the authority to acquire, manage, own, use, pledge, encumber, or otherwise dispose of the following: 
A. Tribal Property. Tribal properties of a real or personal nature subject to any conditions set out in the Tribal Council's resolution authorizing the transfer of such properties to AMPS.

B. Funds. All funds which AMPS may acquire by grant, gift, loan or other means.

C. Other Real and Personal Property. All interests in real and personal property whether of a tangible or intangible nature, AMPS may acquire by grant, gift, loan, purchase, lease or other means.

Case Study: xxvii NEOS Corporation Tohono O'odham Utility Authority

D. Other assets. All earnings, interest, dividends, accumulations, contract rights, claims and other proceeds arising from the above listed assets.

\section{ARTICLE VII}

Control of Assets

All cash assets shall be deposited, invested, re-invested or paid out pursuant to the contractual obligations of AMPS and in accordance with the standards of prudent business practices so as to ensure the continued existence, integrity and viability of AMPS. Such decisions are reserved exclusively to the Board of Directors of AMPS.

ARTICLE VIII

Asset Distribution/Dissolution

AMPS shall determine in its sole discretion as to when a payment is to be issued and the amount of any such payment. Upon dissolution of AMPS, the remaining assets, after payment of all debts and liabilities, shall be returned to the Tribe. In no event shall the Fort Mojave Tribe be liable for any debts or liabilities of AMPS.

\section{ARTICLE IX \\ Board of Directors}

The Board of Directors of AMPS shall consist of seven (7) members and is hereby vested with all powers necessary to carry out the purposes of AMPS. The initial members shall be selected by the Fort Mojave Tribal Council. There are no prohibitions against the Fort Mojave Tribal Council serving as the Board of Directors. Members of the Board need not be enrolled members of the Fort Mojave Tribe. However, no more than three (3) Board members of AMPS may be nonmembers of the Fort Mojave Indian Tribe. The Board members' term of office and their qualifications shall be specified in the Bylaws.

ARTICLE X

Registered Office and Registered Agent

The address of AMPS's registered office is Office of the Chairperson of AMPS, Fort Mojave Indian Reservation, 500 Merriman Avenue, Needles, California 92363, and the registered agent at this address is the Chairperson of AMPS.

\section{ARTICLE XI}

Advisory Board

The Tribal Council of the Fort Mojave Tribe shall act as the Advisory Board to the Board of Directors of AMPS for the purpose of providing information and advice to the Board regarding political, cultural and social issues that concern the Tribe and its members.

Case Study: xxviii NEOS Corporation Tohono O'odham Utility Authority ARTICLE XII

\section{Trustee}

AMPS is the trustee of all assets owned or controlled by AMPS on behalf of the Fort Mojave Indian Tribe.

\section{ARTICLE XIII}

Litigation

The Fort Mojave Tribe reserves the right to challenge in whatever forum all matters involving AMPS which, in the opinion of the Fort Mojave Tribe, affect its rights, privileges and immunities as a sovereign government. Before initiating or entering an appearance in any such litigation or 
administrative proceeding, AMPS shall give at least thirty (30) days, or such time as the court rules allow, prior written notice to the Chairperson of the Fort Mojave Tribe.

\section{ARTICLE XIV}

Waiver of Immunity

The acts or omissions of AMPS, whether pursuant to the powers enumerated in Article III or otherwise, shall not create any liability, obligation or indebtedness either of the Fort Mojave Indian Tribe or payable out of assets, revenues or income of the Tribe, and only the assets, revenues and income held by or in the name of AMPS shall be subject to, to the extent otherwise permitted herein and by law, to the debts, obligations or other liabilities created or incurred by AMPS. Any waiver of immunity of or by AMPS shall not be construed to waive any immunity of the Fort Mojave Indian Tribe or any other covered persons and entities or extend any liability to any assets, revenues or income of the Fort Mojave Indian Tribe.

\section{RESOLUTION}

BE IT RESOLVED, that the foregoing Charter of the Aha Macav Power Service, be and the same is hereby adopted, as amended. Upon adoption of the amended Bylaws of the Aha Macav Power Service by the Board of Directors, two signed duplicate originals shall be delivered to the office of the Tribal Secretary of the Fort Mojave Tribal Council.

BE IT FURTHER RESOLVED, that the Chairperson and the Secretary of the Fort Mojave Tribe are authorized and instructed to sign this resolution for and on behalf of the Fort Mojave Tribal Council.

\section{Certification}

We, the undersigned, Chairperson and Secretary of the Fort Mojave Tribal Council, hereby certify that the Fort Mojave Tribal Council met on this day and by a vote of 6 in favor and 0 opposed in a duly called and convened meeting of the Council, adopted the foregoing resolution. Dated this 13th day of July, 1991.

Case Study: xxix NEOS Corporation Tohono O'odham Utility Authority

(signature)

Chairperson

Fort Mojave Tribal Council

ATTEST:

(signature)

Secretary

Fort Mojave Tribal Council 


\section{Mni Sose Intertribal Water Rights Coalition, Inc.}

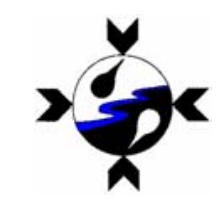

\section{MODEL ENERGY AND UTILITY SERVICE CODE DRAFT}

\section{CHAPTER I: GENERAL PROVISIONS}

\section{SECTION 1.01 SHORT TITLE:}

This code shall be entitled the "Energy and Utility Service Code" and shall be a title within the Tribal Ordinances.

\section{SECTION 1.02 AUTHORIZATION AND REPEAL OF INCONSISTENT LEGISLATION:}

1. Authority for this Title is found in the Indian Reorganization Act of June 18, 1934 (48 Stat. 984) as amended, and under Article of the Tribe's Constitution and Bylaws. The Tribe is a federally chartered tribal corporation that possesses sovereign powers of government within the geographical boundaries of the Reservation. The Chairman of the Tribal

Council and the Tribe are authorized to make and enforce this law pursuant to the authorities described above and their status as a sovereign Federally Recognized Indian Tribe.

2. Pursuant to the Tribe's retention of the full spectrum of sovereign powers, the Tribal Council has the authority, desires to and does hereby establish this Title in order to further the best interests of the Tribe, its members and their communities and for the purposes of managing the natural gas, electrical, telecommunications, railroad, sewer, water and other utility functions of the Tribe, and to regulate all such matters of Third Parties on the Reservation, and for the purposes of facilitating economic development of the Reservation, and providing and saving tribal revenues by effectively managing tribal utility resources.

3. Any prior Tribal regulations, resolutions, orders, motions, legislation, codes or other Tribal laws which are inconsistent with the purposes and procedures established by this Title are hereby repealed to the extent of any such inconsistency. 


\section{SECTION 1.03 JURISDICTION}

1. This Title shall be applicable to all natural gas, electric, water, sewer, telecommunication and railroad services provided on the Reservation.

2. Chapter VII, regarding Negotiation of Rights of Ways Across the Reservation, shall be applicable to all crossings of Reservation lands by wires, pipelines, fiber, rail, or other conduits and related facilities for transmitting or transporting energy, telecommunications, water/sewer or utility related products or information, when such crossings require the use of Tribal land rights ${ }^{1}$.

3. Enforcement of this Title shall be as described herein, or pursuant to the Tribal Court System.

4. To the extent any agreement exists with any Third Party which conflicts with the provisions in this Title, the agreement shall control.

\section{SECTION 1.04 DEFINITIONS}

1. Tribal Council: "Tribal Council" means the governing body of the Tribe, established pursuant to Article ___ of the Constitution of the Tribe.

2. Franchise: A "Franchise" is the right to provide energy, telecommunication, or other public utility services under the jurisdiction of this Title within the Reservation. A Franchise may be "Exclusive" which means that only one entity has the right to provide services within the franchised area, or "Nonexclusive" which means that more than one entity may provide similar services within that franchised area.

3. Order: An "Order" is a decision of the Public Utilities Committee regarding a franchise, which sets or adjusts rates and tariffs, prescribes or enforces rules and regulations, or is otherwise necessary and convenient to carry into effect the provisions of this Title. ${ }^{2}$

4. Public Utility: The term "public utility" means every corporation, company, individual, or association that owns, controls, operates or manages, except for private use, any equipment, plant or generating machinery, transmission lines or pipelines or produces, transmits, delivers, or furnishes heat, light, water, sewer, telephone or rail service, or power. ${ }^{3}$

5. Public Utilities Committee ${ }^{4}$ : The "Public Utilities Committee" refers to the Tribal committee established hereunder with the authority and jurisdiction to supervise and control the public utilities described herein. ${ }^{5}$

\footnotetext{
${ }^{1}$ Possible include a another section for crossing of allotted lands.

${ }^{2}$ Kan. Stat. Ann. Sections 66-101 and 66-101(g).

${ }^{3}$ See, e.g. Kan. Stat. Ann. Section 66-104 (a), et seq. and 79-5a01

${ }^{4}$ Kansas' Public Utilities Code establishes a State Corporation Commission, generally referred to as the Public

Utilities Commission, to govern public utility providers and services. To distinguish the State Commission from the
} 
6. Reservation: "Reservation" means the territory within the present confines of the exterior boundaries of the Reservation, and all lands outside the exterior boundaries of the Reservation which are under the jurisdiction of the Tribe(s), and such other lands without such boundaries as may be added thereto under any laws of the United States.

7. Third Party: A Third Party is any party not already referenced. ${ }^{6}$

8. Tribe or Tribal: "Tribe or Tribal" shall refer to the Kickapoo Tribe in Kansas, the Prairie Band Potawatomi Nation, the Sac \& Fox Nation of Missouri in Kansas, or the Iowa Tribe of Kansas and Nebraska, individually or collectively.

\section{SECTION 1.05 PERIOD OF DURATION}

This Title _ shall be perpetual, or until revoked or surrendered by action of the Tribal Council.

\section{CHAPTER II: PROHIBITION OF STATE TAXES}

\section{SECTION 2.01 STATE TAXES PROHIBITED}

All entities providing services under this Title are hereby prohibited from assessing, or including within invoices or bills sent to any entity within the Reservation, for service provided within the Reservation, any tax, tariff, or collection established or imposed by the State of Kansas and not explicitly approved or ratified by the Tribal Council, or its designee.

\section{CHAPTER III: PUBLIC UTILITY COMMITTEE}

\section{SECTION 3.01 CREATION OF PUBLIC UTILITY COMMITTEE}

A Public Utility Committee is hereby established which shall have the purposes, powers, and authorities described herein. The Public Utility Committee may herein be referred to as the "Committee".

Tribal entity this Article creates, is called a "Committee" for the purposes of this document. See generally, Chapter 66 of Kan. Stat. Ann.

${ }^{5}$ This body can be called by another name at your discretion.

${ }^{6}$ If a tribal utility is formed in the future, this code may be amended to exclude the tribal utility from these requirements if needed. 


\section{SECTION 3.02 GENERAL PURPOSES, POWERS \& AUTHORITY OF PUBLIC UTILITY COMMITTEE}

1. The purpose for which the Committee is organized is to provide an entity through which the Tribe may regulate the actions of Third Parties providing services related to all natural gas utility, electrical utility, other energy utility, water, sewer and telecommunications services. The Committee may also regulate certain railroad functions as described herein ${ }^{7}$.

2. The Committee shall have the power and authority to consider and adopt rules, terms and conditions relating to the quality and character of each kind of product or service to be furnished or rendered by any public utility furnishing such product or service within the Reservation; to require and permit any public utility to make such additions or extensions to its physical plant as may be reasonable and necessary for the benefit of the public, and may designate the location and nature of such additions and extensions and the time within which such shall be completed; and to provide a reasonable and lawful penalty for noncompliance with any of the provisions adopted hereunder. ${ }^{8}$

\section{SECTION 3.03 SPECIFIC POWERS AND AUTHORITY OF PUBLIC UTILITY COMMITTEE}

The Public Utility Committee is authorized to do the following:

1. To adopt reasonable and proper rules and regulations to govern its proceedings, including the assessment of costs on any complaint brought hereunder, and to regulate the mode an manner of all investigations, tests, audits, inspections and hearings not specifically provided for herein, ${ }^{9}$ to request, receive and analyze information, to hold meetings or informal hearings, and to deliberate as necessary to fulfill its function as described in this Title.

2. To issue Orders binding on Third Parties acting on the Reservation pursuant to this Title.

3. To prescribe rules and regulations for the performance of any service or the furnishings of any commodity under its jurisdiction by including such rules in Franchise documents.

4. To employ or appoint employees, agents, or contractors and to define their duties and fix their compensation.

5. To order improvements to the service or facilities of Franchisees.

6. To ascertain the value of the property of every Franchisee and every fact which, in its judgment, may or does have any bearing on such value.

\footnotetext{
${ }^{7}$ These railroad functions are not enumerated, but are generally described in Kan. Stat. Ann. Chapter 66.

${ }^{8}$ Kan. Stat. Ann. Sec. 66-133 (1-3)

${ }^{9}$ Kan. Stat. Ann. Sec. 66-106(a)
} 
7. To order a surcharge on rates under their jurisdiction sufficient to cover the reasonable costs of the Committee's operation.

8. To apply for and administer grants consistent with the purposes of this Title , e.g. prepare and submit a residential energy conservation plan to the federal secretary of energy and receive and disburse and federal funds appurtenant thereto. ${ }^{10}$

9. To investigate any written complaint made against any public utility governed by the title that any of the rates, rules, regulations, acts or practices of such utility are in any respect unreasonable, unfair, unjust, unjustly discriminatory or unduly preferential, or both, or that any service performed for the public is unreasonably inadequate, inefficient, unduly insufficient or cannot be obtained. ${ }^{11}$

10. To make joint investigations, hold joint hearings within or without the Reservation, or issue joint or concurrent orders in conjunction or concurrence with any official, agency, instrumentality or commission of any Tribe or State of the United States. ${ }^{12}$

11. To participate on regional boards or bodies and to participate on national tribal boards or bodies, as is approved by the Tribal Council.

12. Other authorities necessary and convenient to accomplish the duties described in this Title

13. To declare it necessary and in the public interest to acquire and control any franchise supplying water, natural or artificial gas, electric light or power or heat, in the event the franchise of a public utility has expired. ${ }^{13}$

14. To make recommendations to the Tribal Council on various matters relating to this Title.

\section{SECTION 3.04 LIMITATIONS ON POWERS OF PUBLIC UTILITY COMMITTEE}

The Public Utility Committee shall have no power:

1. To expressly or by implication enter into any agreement of any kind on behalf of the Tribe.

2. To pledge the credit or assets of the Tribe.

3. To dispose of, pledge, or otherwise encumber real or personal property of the Tribe.

4. To waive any right, privilege, or immunity of the Tribe or to release any obligation owed to or by the Tribe.

\footnotetext{
${ }^{10}$ Kan. Stat. Ann. Sec. 66-1,186

${ }^{11}$ Kan. Stat. Ann. Sec. 66-101e

${ }^{12}$ Kan. Stat. Ann. Sec. 66-106(2)(c).

${ }^{13}$ Kan. Stat. Ann. Sec. 12-811
} 


\section{SECTION 3.05 PUBLIC UTILITY COMMITTEE OPERATIONS}

1. The Committee members shall in all cases act as a board, regularly convened, by a majority vote, and they may adopt such rules and regulations for the conduct of their proceedings as they may deem proper, not inconsistent with this Title, and applicable tribal or federal law.

2. A majority of the Committee shall be members of the Tribe. A Committee member's duties shall be performed in good faith, in a manner the member believes to be in or not opposed to the best interests of the Tribe, and with such care as an ordinarily prudent person would use under similar circumstances in a like position.

3. The initial Committee may consist of a subcommittee of the Tribal Council and other members as are appointed by the Tribal Council. The number of Committee members shall be five, but may thereafter be increased or decreased at any time by a duly adopted resolution of the Tribal Council.

4. The Committee shall elect from its own number a Chairperson and a Vice Chairperson and shall appoint a secretary to keep a record of its proceedings. ${ }^{14}$ The Chairperson shall be responsible for presiding over meetings of the Committee. The Vice Chairperson shall assume the duties of the Chairperson in the absence of the Chairperson. In the event of a tied vote, the vote of the Chairperson shall break the tie. A quorum of Committee members shall consist of a majority of Committee members. In the event of a quorum not being present, a lesser number may adjourn the meeting from time to time without further notice.

5. Regular or special meetings of the Committee may be called upon the request of the Chairperson or of any two Committee Members. Notice of meetings, other than the regular meeting shall be given by service upon each Committee Member in person orally at a preceding meeting; or by telephone or mailing to the last known post office address of the member, at least three days before the date therein designated for such meeting, including the day of mailing. Such notice shall specify the time and place of such meeting, and the business to be brought before the meeting. No business other than that specified in such notice shall be transacted at any special meeting.

6. Each Committee Member shall have one vote.

7. The Committee shall hold an annual meeting with the Tribal Council beginning with the year 2002. The meeting shall be for the purpose of reporting on the annual activities and business that may come before the Committee. Notice of the meeting shall be posted at customary and appropriate public notice locations at least 30 days in advance of the meeting.

8. The meetings of the Committee shall be publicly noticed and open to the public ${ }^{15}$, unless deliberation of the Committee over issues before it requires that the Committee declare an executive session. To the extent practical, executive sessions shall be declared as such in the public notices. On important matters affecting the residents of the Reservation, the

\footnotetext{
${ }^{14}$ Kan. Stat. Ann. Sec. 13-1221(a)

${ }^{15}$ Kan. Stat. Ann. Sec. 13-1222
} 
Committee shall publish in the Tribal newspaper the nature of the matter and Committee meeting times. The Committee may, in its discretion, hold formal public meetings to better understand the views of Reservation customers and service providers and Franchisees, and to better determine the best interests of the Tribe.

\section{SECTION 3.06 ORDERS OF THE PUBLIC UTILITY COMMITTEE}

1. The Committee may regulate Third Parties under its jurisdiction by issuing one of the following types of Orders:

a. Orders Approving Franchises or Disapproving a Franchise under Chapter IV of this Title. An Order Disapproving a Franchise may contain a listing of requirements to be met for reconsideration.

b. Orders Approving Rates or Tariffs or Disapproving Rates or Tariffs under Chapter V of this Title. An Order Disapproving a Rate or Tariff may contain a listing of requirements to be met for reconsideration.

c. Orders Enforcing conditions of Franchises or Rates or Tariffs under Chapter VI of this Title.

2. The Committee shall create a process consistent with the provisions of this Title leading up to the issuance of each of the above types of Orders. When the process is initiated by the Committee by the issuance of a Notice of Franchise pursuant to Chapter IV of this Title, or by issuance of a Notice of Ratemaking pursuant to Chapter V of this Title, or by issuance of a Notice of Enforcement pursuant to Chapter VI of this Title, such Notice shall be accompanied by a tentative schedule for completion of the process and ultimate issuance of the Order.

3. All Orders must be approved by and signed by at least a majority of the members of the Committee.

4. All orders, regulations, services, rates, classifications, etc. fixed by the Committee shall be in force and effect 30 days after approved and shall be prima facia reasonable unless changed or modified by the Committee, Tribal Council or Tribal Court. ${ }^{16}$

\section{SECTION 3.07 COMPENSATION FOR PUBLIC UTILITY COMMITTEE}

1. The Committee members shall receive such compensation for their services as may be determined by the Tribal Council.

2. Committee members shall be entitled to compensation for their actual and necessary expenses, including travel expenses, incurred in the performance of their duties as members

\footnotetext{
${ }^{16}$ Kan. Stat. Ann. Sec. 66-115
} 
of the Committee. All requests for reimbursement must be approved by the Committee Chairperson and verified by receipts. ${ }^{17}$

\section{SECTION 3.08 TERMS OF SERVICE FOR MEMBERS OF PUBLIC UTILITY} COMMITTEE

1. Committee members shall be appointed for staggered terms: one position for an initial period of 1 year, two positions for an initial period of 2 years, and two positions for an initial period 3 years. Thereafter, all terms shall be for 3 years.

2. Committee members may resign by submitting written notice of their resignation, and the Tribal Council at the next Tribal Council meeting shall accept such resignation.

3. Any Committee member may be removed for cause by a majority vote of the Tribal Council at a duly called meeting after the Tribal Council has had the opportunity to fully review the matters constituting cause for removal and after allowing any affected Committee member to appear before the Tribal Council and respond to the allegations which constitute cause for removal. Cause for removal shall be limited to the following:

a. Such Committee member has failed to attend any four meetings of the Committee out of any eight consecutive meetings, unless any of such absences is excused; or

b. Such Committee member has, during his or her term on the Board, been convicted of any crime reflecting upon such member's honesty or ability to fulfill the fiduciary obligations imposed by law upon such member; or

c. The Committee has found, in a meeting where the topic was scheduled for discussion, that the Committee member has committed malfeasance or breached his fiduciary duty to the Tribe.

4. A vacancy shall exist from the date of any Committee meeting after which a member is removed or whose resignation is accepted as provided herein.

5. The Tribal Council will name new appointments to fill any vacancies in the Committee within thirty days after such vacancy occurs. Any vacancy created by the expiration of a Committee member's term may be filled with the exiting Committee member.

\section{SECTION 3.09 ELIGIBILITY TO SERVE ON PUBLIC UTILITY COMMITTEE}

1. To be eligible for election to the Committee an individual must be at least 25 years of age, and have experience in one or more of the following fields:
a. Financial management,
b. Human or natural resources,

\footnotetext{
${ }^{17}$ Kan. Stat. Ann. Sec. 13-1222
} 

c. Utility management,
d. Law,
e. Engineering, or
f. Economic development.

2. A Committee member shall vacate his office if during the term of the office he or she shall be a party to a contract for profit with an entity doing business under the jurisdiction of the Committee, and/or that presents a conflict of interest with the duties of the Committee Member.

\section{SECTION 3.10 GENERAL PROVISIONS APPLICABLE TO PUBLIC UTILITY COMMITTEE}

1. If any section, or any part thereof, of this Title or the application thereof to any party, person, or entity in any circumstances shall be held invalid for any reason whatsoever by a court of competent jurisdiction or by federal legislative enactment, the remainder of the relevant section or part of this Title shall not be affected thereby and shall remain in full force and effect as though no section or part thereof has been declared to be invalid.

2. Nothing in this Title _ shall provide of be interpreted to provide a waiver of the sovereign immunity of the Tribe or any of its governmental officers, employees and/or agents.

\section{CHAPTER IV： FRANCHISES}

\section{SECTION 4.01 FRANCHISE REQUIREMENT}

1. All providers of artificial or natural gas, electric light, water, power or heat, street railways, telegraph and telephone line operators, and other entities providing energy or utility services to customers on the Reservation must obtain a franchise to provide service within the Reservation. ${ }^{18}$

2. All Franchises shall be Nonexclusive. ${ }^{19}$

\footnotetext{
${ }^{18}$ Kan. Stat. Ann. Sec. 12-2001 (a)

${ }^{19}$ Kan. Stat. Ann. Sec. 12-2001(b)(3); Chapters 12 and 13 of the Kansas statutes address the ability of large cities to own water works and electric light plants, issue bonds, establish rates, and generally produce and supply water and power within city limits. No other electricity suppliers are allowed to furnish, distribute and sell electricity to customers within the city unless the municipality has first refused to do so and the city subsequently authorizes it. KSA 13-1235. Presumably, KSA 66-1,175 discussing the EXCLUSIVE right of retail electric suppliers to provide service within certified boundaries, is referring to these city-owed water and power works.
} 


\section{SECTION 4.02 EXISTING AGREEMENTS}

In no way does this title impair existing agreements between the Tribe and Third Parties relating to the provision of services within the Reservation.

\section{SECTION 4.03 PROCEDURES FOR FRANCHISING}

1. Franchises shall be Issued by Order of the Public Utility Committee after consideration of all relevant facts submitted to the Committee, and after consideration of the best interests of the Tribe.

2. Entities with Existing Agreements:

a. Within 60 days after formation of the Public Utility Committee, the Committee shall issue an Order granting non-exclusive franchises to holders of existing agreements.

b. Such franchise shall be for the term of their existing agreement.

c. All such Orders shall be forwarded to the holder of the agreement with a cover letter and copy of this Title.

3. Entities without Existing Agreements:

a. Within 120 days after formation of the Public Utility Committee, the Committee may issue a Notice of Franchise to entities who have not executed an existing service agreement but who are under their jurisdiction and are currently providing service to customers under the jurisdiction of this Title.

b. The Committee shall issue similar Notices of Franchise to all similarly situated entities of which the Committee is aware. The Committee shall also publish a notice that Franchises of the character being noticed are being considered.

c. Each Notice of Franchise shall include the following:

i. A copy of this Title

ii. A requirement that the entity providing service submit an Application for Franchise letter by a date certain requesting a Franchise if they wish to continue providing services within the Reservation. Such Application for Franchise shall contain, in the manner proscribed by the Committee:

1. Information showing how the entity meets or will meet the Obligations of a Franchisee as set forth herein.

2. Information regarding the rates charged for services and each type of services provided.

3. Information regarding the methods by which services are provided.

4. Other information as needed.

iii. Any filing fee requirement, which is to be submitted with the letter requesting a Franchise. 
d. The Committee shall consider all requests for Franchises and shall grant those that are determined to be in the best interests of the Tribe. The Committee may require new Franchisees to negotiate a tribal tax or license agreement for the term of the Franchise as a condition of the Franchise.

e. No person, firm or corporation shall be granted an exclusive franchise, right or privilege whatsoever. ${ }^{20}$

f. Any entity wishing to provide services under the jurisdiction of the Committee on the Reservation shall submit an Application for Franchise and subject itself to the franchising process prior to beginning services.

g. No grant, right privilege or franchise shall be made to any person, firm, corporation or association unless it provides for adequate compensation or consideration therefore to be paid to the Tribe, such fixed charge to consist of a percentage of the gross receipts derived from customers within the Reservation. ${ }^{21}$

\section{SECTION 4.04 OBLIGATIONS OF FRANCHISEE}

1. As a condition for carrying on the commercial transactions on tribal lands and as a condition for the operation and maintenance of facilities on tribal lands to conduct those commercial transactions, all Franchisees shall be bound by the obligations set forth herein.

2. A particular Franchise may contain exemptions from one of more of these obligations. No exemption will be effective unless it explicitly references this Section 4.04 and the exempted subsection number in the Committee's Order granting the Franchise. A particular Franchise may contain additional obligations specific to the service provided.

3. The following obligations attach to Franchises:

a. Obligation to Serve: All Franchisees within the Reservation are obligated to continue providing such services at rates consistent with other customers within the State of Kansas and under service conditions consistent with service to other customers within the State of Kansas until notice has been provided to the Franchisee by the Committee that the provision of service is no longer an obligation, or until the Committee approves rates and/or regulations governing such service which are different from those customarily provided to other customers within the State of Kansas.

b. Public Benefit Funds Collected: All funds collected from customers within the Reservation which are collected for the benefit of the public under a State of Kansas or Committee-approved rate shall be utilized for those purposes to benefit residents of the Reservation. Funds collected from customers within the Reservation may not be used to benefit other customers not within the Reservation.

\footnotetext{
${ }^{20}$ Kan. Stat. Ann. Sec. 12-2001(b)(3)

${ }^{21}$ Kan. State. Ann. Sec. 12-2001(b)(5)
} 
c. Competition: All Franchisees serving customers within the Reservation shall be in competition with others providing similar services, as follows:

i. All infrastructures designed for the delivery of the service shall be open to use by any other service providers. Use of the infrastructure owned by one service provider by another service provider may be subject to charges by the owning entity, however, such charges shall be provided under the same terms and conditions that the service provider owning the infrastructure provides to itself.

ii. Such charges shall be public information, to be shared with interested parties at their request.

iii. Use of the infrastructure shall be provided on a first come-first served basis. All capacity of the infrastructure not in use during the month of a request shall be available for use by the next requesting service provider who has customers ready and willing to use the system.

iv. Capacity for use of the system may be sold in reasonable minimum quantities.

v. Any customer switching to a new service provider using the same infrastructure must do so in writing.

d. Publication and Filing of Rates, Rules and Regulations and Contracts:

i. All public utilities shall publish and file with the Committee, in such form and at such time as the Committee may prescribe, copies of all schedules of rates or tariffs, rules and regulations and contracts between public utilities pertaining to any and all jurisdictional services to be rendered by such public utilities. ${ }^{22}$

ii. Maps of their service territory and the infrastructure therein. The Committee may require that such maps may be in an electronic format sufficient for input into a GIS database.

iii. The annual measured usage of each service provided on the Reservation.

iv. The annual measured usage of each service provided to the Tribe and/or its subsidiaries, if such Tribal customer makes use of the service provided within the Reservation.

v. The annual amount of any Public Benefits Funds collected, and the manner of use of those funds.

vi. An annual corporate report verified by the oath of an officer thereof.

vii. Other information as is requested by the Committee after reasonable notice.

e. Quality and Reliability of Service:

i. All Franchisees shall establish and maintain reasonably sufficient and efficient service $^{23}$ consistent with service provided to similarly situated customers within the State of Kansas. The Committee may Order higher standards of reliability where such standards are in the best interest of the Tribe, however, the Committee shall also approve rate increases as necessary and just to fund needed infrastructure or technical improvements for meeting such higher standards.

ii. A Franchisee's revenues will also be reduced where electricity providers sell to others or retire facilities which cause a decrease in electrical generating capacity

${ }^{22}$ Kan. Stat. Ann. Sec. 66-101c

${ }^{23}$ Kan. Stat. Ann. Sec. 66-101b 
and decrease the power available to the reservation or tribal customers, upon a finding that such actions were inefficient or imprudent. ${ }^{24}$

iii. A lack of prudence shall be presumed, and revenues reduced accordingly, if any tribal, state or federal entity assesses a fine or penalty for safety or quality assurance violations against a public utility. ${ }^{25}$

f. Tribal Employment: tribal employment laws and quotas for hiring of tribal members shall bind all Franchisees.

g. Metering and Billing:

i. Meters shall at all times be properly calibrated so that accurate measurement of services used is maintained. Evidence of such calibration shall be provided to the Committee upon request. The Committee shall have authority to audit the measurement of all services provided under terms described by the Committee

ii. Bills shall be in a format which provides information to customers in a manner that is easy to understand and which promotes conservation of resources.

h. Disconnection or Discontinuation of Service Policies: Franchisees shall maintain reasonable public policies for disconnection of customers and for discontinuation of service to customers. Such policies shall provide for reasonable notice prior to disconnection, except in the case of emergencies.

i. Provision of Data: Franchisees shall furnish to the Committee, in such form and such detail as the Committee shall prescribe, all tabulations, computations, and all other information required by it to carry into effect any of the provisions of this Title

and shall make answers to the best of their knowledge, to all questions submitted by the Committee. Whenever required by the Committee, every Franchisee shall deliver to the Committee copies of any and all maps, profiles, contracts, agreements, franchises, reports, books, accounts, papers and records in its possession or in any way relating to its property or affecting its business containing evidence relating to the merits of or pertinent to the hearing of any issue pending before the Committee.

j. Inventory of Physical Properties: Franchisees shall file with the Committee an inventory of all its physical properties on the Reservation, designating the exact location of its property. Such inventory shall show in detail the cost of construction together with the depreciation charges incident thereto since construction, or may show the replacement cost of such properties, if in the opinion of the Committee the original cost and depreciation charges cannot be obtained. In the event any Franchisee refuses or neglects to file such inventory, or the inventory so filed is inaccurate, the Committee may send its agents upon the ground and make an inventory as desired by the Committee. The entire cost of making such inventory by the agents of the Committee shall be paid by the Franchisee from its profit and loss account and shall not be charged to operating expenses, and such payment shall be made to the Tribe.

\footnotetext{
${ }^{24}$ Kan. Stat. Ann. Sec. 66-128(j)
}

${ }^{25}$ Kan. Stat. Ann. Sec. 66-128(i) 
k. Improvements: Franchisees shall make improvements to their existing plant, scales, equipment, apparatus, facilities or other physical property, or erect new structures in a manner and within the time specified by the Committee upon a finding of the Committee, after the opportunity to be heard by the Franchisee, that such improvement, addition, extension, repair or change promotes the security or convenience of its employees or the public.

1. Interconnection Standards and Obligations: Franchisees shall maintain reasonable public policies for interconnection to their facilities. No Franchisees shall disapprove an interconnection that meets national standards of safety and reliability. The Tribe and its subsidiaries shall have the right to interconnect wholesale or retail facilities to the facilities of any Franchisee under the same terms and conditions as the Franchisee interconnects to its own facilities.

m. Joint Use of Equipment: Franchisees shall permit the use of their conduits, subways, tracks, wires, poles, pipes or other equipment or any part thereof on, over, or under any street or highway, by any other Franchisee, after an opportunity to be heard, upon Order of the Committee. The Order shall include findings that:

i. Public convenience and necessity require the joint use of poles or facilities,

ii. Such use will not result in irreparable injury to the owner or other users of the equipment,

iii. That such Franchisees have failed to agree upon such use or the terms and conditions or compensation for the same,

iv. The Franchisee to whom the use is permitted is liable to the owner, or other users of such conduits, subways, tracks, wires, poles, pipes, or other equipment for such damage as may result from their use, and

v. Appropriate compensation is set forth.

n. Safety: Franchisees shall act in a manner as to promote and safeguard the health and safety of its employees, customers, and the public, and to this end to prescribe the installation, use, maintenance, and operation of appropriate safety or other devices and appliances, and to establish appropriate standards of equipment, and to require the performance of any other act necessary for the health or safety of its employees, customers, or the public

o. Authority to Enter Premises: Franchisees shall allow Members of the Committee and their agents to enter upon any premises occupied by any Franchisee for the purpose of making the examinations and tests and exercising any of the other powers provided for in this Title _ and to set up and use on such premises any apparatus and appliances necessary therefore. The agents and employees of such Franchisee shall have the right to be present at the making of such examination and tests.

p. Net Metering: All electrical utility Franchisees shall have policies providing for Net Metering on the Reservation. Net Metering is the ability of utility customers to install distributed generation behind the Franchisee's meter and to run that generator as 
needed, while the meter nets power coming in to the customer and the power going out of the customer's meter.

q. Energy Conservation: Franchisees shall promote energy conservation as is set forth in 4.05.

r. Low Income Programs: Franchisees shall maintain a program for subsidizing low income persons within the Reservation as is set forth in 4.06 .

s. Environmental Obligations: Franchisees shall protect the environment as is set forth in 4.07 and in other Federal and Tribal laws.

t. Special Responsibilities: Franchisees shall have the special utility responsibilities set forth in 4.08 and in other Federal and Tribal laws.

u. Maintenance: Franchisees shall have the maintenance obligations as set forth in 4.09.

v. Federal Regulations: Franchisees shall have all obligations described in federal regulation, including but not limited to those set forth in 25 U.S.C. Sec.169.5.

\section{SECTION 4.05 ENERGY CONSERVATION}

1. Weatherization: Franchisees providing electrical utility related services shall promote the weatherization of tribal buildings through programs similar to those available to customers within the State of Kansas. Any state or federal funds received for these programs by the Franchisee shall be available for use within the Reservation, if like funding is not also available to the Reservation.

2. Energy Efficiency: Franchisees providing electrical utility related services shall promote efficient use of energy through educational programs, technical assistance programs, energy audits, and financial assistance for improving energy efficiency. Any state or federal funds received for these programs by the Franchisee shall be available for use within the Reservation, if like funding is not also available to the Reservation.

\section{SECTION 4.06 LOW INCOME PROGRAM}

1. Franchisees providing electrical utility related services shall maintain a program for subsidizing low income persons within the Reservation through programs similar to those available to customers within the State of Kansas. Any state or federal funds received for these programs by the Franchisee shall be available for use within the Reservation, if like funding is not also available to the Reservation. 
2. The Tribe may provide Franchisees with names of customers eligible for these programs if the Tribe determines that the elderly or handicapped, or others should receive a preference in this program. ${ }^{26}$

\section{SECTION 4.07 ENVIRONMENTAL OBLIGATIONS}

1. Facilities on Reservation: Franchisees shall be bound by Federal and Tribal environmental laws regarding all facilities on the Reservation. Franchisees have a duty to protect plants, animals, water, air, and land within the Reservation while doing business on the Reservation and shall adjust their practices when environmental harm can be avoided. Franchisees shall work with the Tribal Environmental, Fisheries, and Cultural Resources offices when issues arise regarding their actions within the Reservation.

2. Notice of Off-reservation Environmental Issues: Franchisees shall provide written notice to the Tribe of all new activities or proposals of the Franchisee that may have a significant impact on the regional environment. Such notice is required of, but not limited to:

a. Proposed construction of new facilities likely to cost over $\$ 50,000$.

b. Proposed changes in company policy significantly affecting the environment.

c. Applications for licenses or extension of licenses to Federal entities.

d. Transfer of significant ownership of assets of the company.

e. Major Federal or State initiatives.

3. No energy utility providing service to this Reservation or its customers shall consider the use of any renewable energy source other than nuclear as the basis for establishing higher rates or surcharges for any service or commodity, nor shall such utility subject any customer utilizing any renewable energy source to any other prejudice or disadvantage on account of the use of any such renewable resource. ${ }^{27}$

\section{SECTION 4.08 SPECIAL UTILITY REPONSIBILITIES}

In exercising its functions within the boundaries of the Reservation, the Franchisee shall adhere to the following principles:

1. No Franchisee shall, as to rates, charges, service, facilities or in any other respect, make or grant any preference or advantage to any corporation or person or subject any corporation or person to any prejudice or disadvantage. No Franchisee shall establish or maintain any unreasonable difference as to rates, charges, service, facilities or in any other respect, either as between localities or as between classes of service

2. Except in emergency situations, the Franchisee shall use reasonable efforts to include the customers within the boundaries of the Reservation in the decision making processes which it undertakes for decisions directly affecting service within the Reservation.

\footnotetext{
${ }^{26}$ See e.g. Kan. Stat. Ann. Sections 13-1227 and 13-1228.

${ }^{27}$ Kan. Stat. Ann. Sec. 66-117(d)
} 
3. All powers of the Franchisee shall be exercised in good faith and in a manner believed to be in the best interests of the Tribe and Franchisee's customers.

\section{SECTION 4.09 MAINTENANCE OBLIGATIONS}

1. All Franchisees shall give notice to the Tribe prior to entering the Reservation for maintenance purposes. Such notice shall include a description of the maintenance to be performed and the time line for the procedures. In the case of an emergency, best efforts shall be made to provide such notice. Franchise documents shall provide the point of contact for notice.

2. Franchisees shall allow Tribal representatives to accompany them during maintenance. Tribal representatives shall have the authority to establish reasonable procedures for protection of cultural plants, cultural places, and the environment.

3. Franchisees shall keep the trimming of trees and other vegetation to a minimum. Franchisees shall consult with Tribal representatives prior to trimming trees or clearing rights of ways. Such Tribal representatives shall have the authority to establish reasonable procedures for trimming of trees and clearing of rights of ways, after consideration of safety and reliability issues described by Franchisee.

\section{SECTION 4.10 OWNERSHIP OF WIRES AND FACILITIES}

1. Unless an easement or right-of-way document signed by the Tribe and approved by the Bureau of Indian Affairs exists with regard to Franchisee facilities, no Franchisee holds real property rights or may claim that real property rights have been transferred due to the existence of facilities on the Reservation. All facilities without such documentation are deemed to be personal property.

2. Any new facilities installed on the Reservation by Franchisees in order to extend service to new customers shall be the personal property of the Tribe, and not the personal property of the Franchisee, when the new facilities are paid for by the new customer or by a particular user. The Franchisee shall provide notice to the Tribe of each such facility constructed.

3. Any facilities which are the personal property of the Tribe pursuant to this Section that are used by Franchisee to deliver their product or service shall be operated and maintained by the Franchisee in a manner consistent with the operation and maintenance of their own facilities. 


\section{SECTION 4.11 TERM OF FRANCHISE}

Each Franchise shall explicitly describe its starting and ending date. No Franchise shall be granted or extended for any longer period of time than 20 years $^{28}$ from the date of such grant or extension, unless a previous agreement controls such term.

\section{CHAPTER V. RATES AND TARIFFS}

\section{SECTION 5.01 RATE OBLIGATIONS}

1. All charges made, demanded or received by any Franchisee for any product or commodity furnished or to be furnished or any service rendered or to be rendered shall be just and reasonable. ${ }^{29}$ Every unjust or unreasonable charge made, demanded or received for such product or commodity or service is prohibited and declared unlawful ${ }^{30}$.

2. All rates for standard services shall be publicly available to customers.

3. No Franchisee or public utility governed by this Title, shall knowingly or willfully charge, demand, collect or receive a greater or less compensation for the same class of service performed by it within the state, or for any service in connection therewith, than is specified in the printed schedules or classifications, including schedules of joint rates; or demand collect or receive any rate joint rate, toll, fare or charge not specified in such schedule or classification. ${ }^{31}$

4. Rates different from those specified in the published schedule or classification of rates may be charged by any public utility or railway, by agreement with the customer or in cases of charity, emergency, festivity or public entertainment. Additionally, public utilities may grant to the officers, employees and agents of such utility free or reduced rated or service upon such terms and conditions previously instituted. ${ }^{32}$

\section{SECTION 5.02 PROCEDURES FOR RATE SETTING}

1. Rates for services provided on the Reservation shall be approved by Order of the Public Utility Committee after consideration of all relevant facts submitted to the Committee, and after consideration of the best interests of the Tribe.

2. Entities with Existing Rates for Services Provided on the Reservation:

\footnotetext{
${ }^{28}$ Kan. Stat. Ann. Sec. 12-2001(b)(2)

29 "Just and reasonable" rates are referenced throughout the state public utilities code, see, for example, Kan. Stat. Ann. Sec. 66-1,202.

${ }^{30}$ The goal was to make the standard the same so rates would be set based on the non-Reservation customers' rates for the convenience of utility companies.

${ }^{31}$ Kan. Stat. Ann. Sec. 66-109

${ }^{32}$ Id.
} 
a. Within 60 days after receiving a Franchise, entities with existing rates for services approved by another regulatory body shall file with the Committee and shall print and keep open to public inspection schedules showing all rates, tolls, rentals, charges and classifications collected or enforced, or to be collected or enforced, together with all rules, regulations, contracts, privileges and facilities which in any manner affect or relate to such rates, tolls, rentals classifications or service. The schedules shall be accompanied by a description of each category of the charges and a description of the calculation of the rates.

b. The Committee may approve the rates, or may make inquiry regarding the rates.

c. After all inquiries of the Committee are satisfied, the Committee shall approve the rates by Order or suggest changes to the rates consistent with this Title

3. Entities without Existing Rates for Services Provided on the Reservation:

a. Concurrent with their Application for Franchise, entities without existing rates for services approved by another regulatory body shall file proposed schedules of rates or tariffs with the Public Utility Committee along with a description of each category of the charges and a description of the calculation of the rates.

b. The Committee may approve the rates, or may make inquiry regarding the rates and suggest changes to the rates consistent with this Title

c. After all inquiries of the Committee are satisfied, the Committee shall approve the rates by Order.

4. The Committee may, in their sole discretion, Order an approval of special rates for one or more large users of a particular utility service, however, such negotiated rates shall be demonstrated to be fair to all other customers and in the best interest of the Tribe. ${ }^{33}$

\section{SECTION 5.03 CHANGES IN RATES AND SERVICE ${ }^{34}$}

1. Unless the Committee otherwise Orders, no Franchisee or public utility shall make effective any changed rate, joint rate, toll, charge or classification or schedule of charges, or any rule or regulation, contract or practice pertaining or service except by filing with the Committee a schedule showing the changes desired, plainly indicated by proper reference marks in amendments or supplements to existing tariffs, schedules or classification or new issues thereof, at least 30 days prior to the proposed effective date, ${ }^{35}$ and obtaining the Committee's consent to such change. ${ }^{36}$

\footnotetext{
${ }^{33}$ Municipal utilities can fix special rates for water and electricity furnished to the city for such public purposes as street lighting or traffic signals, or to organized institutions of charity. KSA Sections 13-1227 and 13-1228.

${ }^{34}$ Based on Kan. Stat. Ann. 66-117

${ }^{35}$ Kan. Stat. Ann. Sec. 66-117(a)

${ }^{36}$ Kan. Stat. Ann. Sec. 66-117(d)
} 
2. The Committee may, upon complaint or its own motion, give notice and hold a public hearing upon such proposed changes. Pending such hearing, the Committee may suspend the operation of schedule and defer the effective date of such change by delivering to the Franchisee a written statement of its reasons for such suspension. The Committee shall not delay the effective date of the proposed change more than 240 days beyond the date the Franchisee files its application requesting the proposed change. If the Committee does not suspend the proposed schedule within 30 days of the date the same was filed, or issue a final Order relating to the change within 240 days of suspending the proposed change, such proposed schedule shall be deemed approved by the Committee and shall take effect immediately. ${ }^{37}$ Any amendment that substantially alters the facts or increases the amount sought shall be deemed a new application and the 240 day period shall begin anew.

3. The Committee, for good cause shown, may allow such change to become effective on less than 30 days notice ${ }^{38}$ by an order specifying the changes so to be made, the time when they shall take effect, and the manner in which they shall be filed and published.

4. Upon a showing by the Franchisee, and a finding by the Committee, that the utility has invested in projects or systems that can be reasonably expected to (a) produce energy from a renewable resource, other than nuclear, for the use of its customers, (b) to cause the conservation of energy used by its customers, or (c) to bring about the more efficient use of energy by its customers, the committee may allow a return on such investment over and above the rate of return fixed for the utility's other investment in property used in its services to the public. ${ }^{39}$

\section{SECTION 5.04 SALE OF FRANCHISE ${ }^{40}$ OR PROPERTY TO BE APPROVED BY COMMITTEE}

1. No Franchisee owning, controlling or operating any property located within the Reservation which is used in the generation, transmission, distribution, or supply of electric power and energy to the Reservation public or any portion thereof shall merge, sell, lease, assign or transfer, directly or indirectly, in any manner whatsoever, any such property or interest therein, or the operation, management or control thereof, or any Franchise covering the same, except when authorized to do so by Order of the Committee.

2. Such Franchisee shall file a verified application setting forth such facts as the Committee shall prescribe or require. The Committee shall review the application.

3. Before Ordering an authorization of the transaction, the Committee shall find the following. The Applicant shall have the burden of showing that the following have been satisfied:

a. That the transaction is consistent with the best interests of the Tribe.

\footnotetext{
${ }^{37}$ Kan. Stat. Ann. Sec. 66-117 (b) and (c)

${ }^{38}$ Kan. Stat. Ann. 66-117(a)

${ }^{39}$ Kan. Stat. Ann. 66-117(e)

${ }^{40}$ Kan. Stat. Ann. Sec. 66-136
} 
b. That the cost of and rates for supplying service will not be increased by reason of such transaction.

c. That the applicant for such acquisition or transfer has the bona fide intent and financial ability to operate and maintain the property.

4. The Committee shall have power to issue said authorization and Order as requested, or to refuse to issue the same, or to issue such authorization and Order with respect only to a part of the property involved. The Committee shall include in any authorization or Order the terms and conditions as in its judgment the public convenience and necessity may require.

\section{CHAPTER VI. ENFORCEMENT OF CONDITIONS OF FRANCHISES OR RATES AND TARIFFS}

\section{SECTION 6.01 ENFORCEMENT}

1. The Tribal Attorney, when requested, shall give the Committee such counsel and advice as the committee may from time to time require. It is hereby made the duty of the Tribal Attorney to aid and assist the Committee in all hearings, suits, and proceedings in which the Committee seeks assistance. ${ }^{41}$

2. The Rates and Charges and Rules and Regulations of the Public Utilities shall at all times be reasonable and just and reasonably necessary in order to maintain reasonably sufficient and efficient service, ${ }^{42}$ and at the instance of the Committee or consumer, such reasonableness may be reviewed and determined by the Tribal Council.

3. The Committee shall have authority to enforce the terms and conditions of Franchises or Rates and Tariffs by ordering fines and penalties as are just and reasonable, designed to compensate the tribe or customers of the Franchisee, or designed to prevent additional breaches of such terms and conditions. Such Orders shall be enforceable by the Tribal Court, upon institution of an action by the Tribal Attorney.

4. If any public utility violates any of the provisions of this Title, or shall do any act herein prohibited, or fails or refuses to perform any duty enjoying upon it in this act, or fails, neglects or refuses to obey any lawful requirement or order made by the Committee, or any ruling of the Tribal Council, it shall, for every such violation, failure or refusal, forfeit and pay to the Tribe a sum of not less than $\$ 5,000$ and not more than $\$ 25,000$. $^{43}$

\footnotetext{
${ }^{41}$ Kan. Stat. Ann. 66-106(c).

${ }^{42}$ See Kan. Stat. Ann. Sections 66-1,202 and 13-431

${ }^{43}$ E.g. Kan. Stat. Ann. Sec. 66-138, and see also Sections 66-139, 66-177, 66-1,151
} 


\section{CHAPTER VII. NEGOTIATION OF LAND RIGHTS ACROSS RESERVATIONS}

\section{SECTION 7.01 PROCEDURE FOR ACQUISITION OF RIGHTS OF WAYS}

1. In addition to the procedure required by the United States Department of Interior Bureau of Indian Affairs, all entities seeking a right of way, easement, real property permit, or any other real property right within the Reservation, whether on land held in trust by the United States or on land owned by one or more Allottees, or on fee owned land, shall use the following procedure:

a. A duplicate Application for right of way as prescribed by federal regulation shall be filed with the Committee.

b. The Committee shall review the Application, and amount and nature of consideration, and shall either make a request to the Applicant that any additional information reasonably necessary for their review of the Application be submitted within a designated time period, or shall inform the Applicant that the Application is adequate for the Committee's initial recommendation to the Tribal Council.

c. Upon receipt of all requested information, the Committee shall review the Application and in the case of a right of way across tribal lands shall make a confidential recommendation to the Tribal Council with regard to the terms and conditions and provisions of the right of way document, and consideration for the right of way.

d. The Tribal Council shall then determine whether to accept the Application, and provide its consent to the Department of Interior pursuant to 25 C.F.R. Sec. 169.3, or to appoint a team to negotiate with the Applicant. The team shall consist of at least one member of the Committee or member of its senior staff, at least one staff member from the Office of the Tribal Attorney, and any other persons as needed.

e. In the case of a right of way across lands belonging to Allottees or others, the Committee shall make a similar confidential recommendation to the Allottees or other. Allottees may then either provide their consent to the Department of Interior pursuant to 25 C.F.R. Sec. 169.3 , or may take any other action deemed necessary. The Committee is authorized, but not required, to provide additional assistance at the request of one or more Allottees.

2. For Right of Ways currently under negotiation at the date this Title becomes effective, Section 7.01 shall not be applicable, however, all other provisions of this Title shall be applicable. 


\section{SECTION 7.02 VALUATION OF RIGHTS OF WAYS}

1. In recognition of the unique land status of the Tribes' Reservation as described in treaty, and in recognition of the special purposes for which this land was reserved from the public domain or other uses by the United States, the granting of real property rights across the Reservation shall only be done with due deliberation and with adequate financial or other consideration.

2. Consistent with 25 C.F.R. Sec. 169.12, such consideration shall be greater than the "fair market value" of off-reservation land rights due to the unique character of Reservation lands and due to the lack of similar or comparable real property transactions for property of this type.

3. The Committee shall recommend appropriate consideration for rights of ways with consideration of the following:

a. The cost to the Applicant of not utilizing Reservation lands.

b. The Applicant's likely earnings, or historical similar earnings from those facilities crossing Reservation lands, in proportion to the whole facility.

c. Previous recent consideration for similar right of way consents.

d. The terms and conditions and provisions of the right of way document.

e. The obligations and requirements of this Title.

f. Any other special circumstances deemed important by the Committee.

\section{SECTION 7.03 TERMS OF RIGHTS OF WAYS}

All rights of ways granted under this Title shall be limited in tenure to 25 years from the date of consent.

\section{SECTION 7.04 TRESPASS CHARGES}

1. For existing rights of way on the Reservation that may expire without the grant of a new right of way being in effect, and if such delay is not a result of tribal or federal action or inaction, charges for trespass shall be the fair market value for purchase of the land in question in fee simple if such land were off of the Reservation, multiplied by the number of months which the facility has been in trespass.

2. The Committee may recommend to the Tribal Council a different amount for Trespass charges, if appropriate.

\section{SECTION 7.05 TRIBALLY RETAINED RIGHTS}

The Tribes shall retain all rights not specifically granted to holders of rights of ways, including but not limited to: 
1. The right to tax property or activities within the right of way.

2. The right to regulate and pass laws regarding property or activities within the right of way.

3. The right to control access to the land within the right of way, except as is superseded by the grant of right of way.

\section{CHAPTER VIII: OBLIGATIONS OF THIRD PARTIES HOLDING LAND RIGHTS ACROSS RESERVATION}

\section{SECTION $8.01 \quad$ INTERCONNECTION}

All holders of rights of ways on the Reservation shall permit the interconnection of tribal facilities, where safety and reliability are not compromised, and where not prohibited by federal or other tribal law.

\section{SECTION 8.02 NOTICES OF ENTRANCE}

1. All holders of rights of ways on the Reservation shall give notice to the Tribe prior to entering the Reservation for maintenance purposes. Such notice shall include a description of the maintenance to be performed and the time line for the procedures. In the case of an emergency, best efforts shall be made to provide such notice. The Committee shall provide the point of contact for notice.

2. All holders of rights of ways on the Reservation shall allow Tribal representatives to accompany them during maintenance. Tribal representatives shall have the authority to establish reasonable procedures for protection of cultural plants, cultural places, and the environment.

3. All holders of rights of ways on the Reservation shall keep the trimming of trees and other vegetation to a minimum. Franchisees shall consult with Tribal representatives prior to trimming trees or clearing rights of ways. Such Tribal representatives shall have the authority to establish reasonable procedures for trimming of trees and clearing of rights of ways, after consideration of safety and reliability issues and other issues described by the right of way document.

\section{SECTION 8.03 NATURAL RESOURCES PROTECTION}

1. Facilities on Reservation: All holders of rights of ways on the Reservation shall be bound by Federal and Tribal environmental laws regarding all facilities on the Reservation. All holders of rights of ways on the Reservation have a duty to protect plants, animals, water, 
air, and land within the Reservation while doing business on the Reservation and shall adjust their practices when environmental harm can be avoided. All holders of rights of ways on the Reservation shall work with the Tribal Environmental, Fisheries, and Cultural Resources offices when issues arise regarding their actions within the Reservation. All holders of right of ways have a duty to restore such right of ways to their pre-construction condition. $^{44}$

2. Notice of Off-reservation Environmental Issues: All holders of rights of ways on the Reservation shall provide written notice to the Tribe of all new activities or proposals of the right of way holder that may have a significant impact on the regional environment. Such notice is required of, but not limited to:

a. Proposed construction of new facilities likely to cost over $\$ 50,000$.

b. Proposed changes in company policy significantly affecting the environment.

c. Applications for licenses or extension of licenses to Federal entities.

d. Transfer of significant ownership of assets of the company.

e. Major Federal or State initiatives.

$\mathrm{N}:$ Working Files $\backslash$ DATA $\backslash$ CODES $\backslash$ Model Energy and Utility Code.doc

\footnotetext{
${ }^{44}$ Kan. Stat. Ann. Sec. 66-1,183
} 